\title{
Jacek Zieliński
}

\section{Pierwszy polski Synod Plenarny w odrodzonej Rzeczpospolitej : okres przygotowań}

Prawo Kanoniczne : kwartalnik prawno-historyczny 48/3-4, 237-299

2005

Artykuł został opracowany do udostępnienia w internecie przez Muzeum Historii Polski w ramach prac podejmowanych na rzecz zapewnienia otwartego, powszechnego i trwałego dostępu do polskiego dorobku naukowego i kulturalnego. Artykuł jest umieszczony w kolekcji cyfrowej bazhum.muzhp.pl, gromadzącej zawartość polskich czasopism humanistycznych i społecznych.

Tekst jest udostępniony do wykorzystania w ramach dozwolonego użytku. 


\section{KS. JACEK ZIELIŃSKI}

Uniwersytet Warmińsko-Mazurski w Olsztynie

\section{PIERWSZY POLSKI SYNOD PLENARNY W ODRODZONEJ RZECZPOSPOLITEJ. OKRES PRZYGOTOWAŃ}

Treść: Wstęp. 1) Ukonstytuowanie się Komisji Przygotowawczej. 2) Ankieta skierowana do biskupów diecezjalnych. 3) Podział prac według tematów w Komisjach specjalnych. 4) Dyskusja Konferencji Episkopatu nad wnioskami Komisji specjalnych. 5) Projekty uchwał. Zakończenie.

\section{Wstęp}

W ogromny wysitek odbudowy państwowości polskiej po odzyskaniu niepodległości przez Polskę czynnie włączyła się społeczność Kościoła katolickiego. Już u zarania wolności osobistości kościelne aktywnie uczestniczyły w tworzeniu zrębów ustawodawstwa polskiego. W tym nurcie mieści się również dzialanie podjęte w związku z Pierwszym Polskim Synodem Plenarnym w odrodzonej Rzeczpospolitej. Proces tworzenia kościelnego ustawodawstwa polskiego byl odpowiedzią na wymagania nowego Kodeksu Prawa Kanonicznego Benedykta XV oraz historyczne zmiany dokonujące się w Polsce. Jak wielkie zadanie wyznaczyli sobie polscy biskupi świadczy czas tworzenia uchwał synodalnych i kolejne przesuwane terminy odbycia synodu. Ku większej przejrzystości, okres ten (lata 1927-1936) podzielić można na następujące przedziały czasowe: 1) Ukonstytuowanie się Komisji Przygotowawczej, 2) Ankieta skierowana do biskupów diecezjalnych, 3) Podział prac według tematów w Komisjach specjalnych, 4) Dyskusja Konferencji Episkopatu nad wnioskami Komisji specjalnych, 5) Projekty uchwal.

Do niniejszego opracowania wykorzystane zostały dokumenty zgromadzone przez Biskupa Przeździeckiego, a znajdujące się 
w archiwach Kurii Diecezjalnej w Siedlcach, oraz bogata literatura przedmiotu ${ }^{1}$.

\section{Ukonstytuowanie się Komisji Przygotowawczej}

Po raz pierwszy sprawę konieczności zwolania synodu poruszono na Konferencji Episkopatu Polski odbytej w Warszawie w dniach 15-17 marca 1927 roku. W trakcie jej trwania zlecono acybiskupowi J. Teodorowiczowi i biskupowi H. Przeździeckiemu przygotowanie referatów dotyczących życia kościelnego w Polsce². Do opracowania tez uzupełniających do powyższych referatów powolano: biskupa tarnowskiego - L. Wałęgę, biskupa stanisławowskiego obrządku

${ }^{1}$ Przebieg I Synodu Plenarnego Rzeczypospolitej Polskiej, Kronika Diecezji Włocławskiej 30 (1936) nr 8-9, s. 329-333; Synod Plenarny, Głos Kapłański 10 (1936), s. 417-423; Synod Plenarny w Czestochowie, Wiadomości Archidiecezjalne Warszawskie 26 (1936) nr 9, s. 389-399; List z Sekretariatu Stanu Jego Światobliwosci do J. Em. Kardynata Kakowskiego z okazji odbytego synodu plenamego w Częstochowie, Wiadomości Archidiecezjalne Warszawskie 26 (1936) nr 10, s. 417-418; Breve Piusa XI mianujace kard. Francesco Marmaggiego legatem papieskim na synod plenarny w Czestochowie, Wiadomości Archidiecezjalne Warszawskie 26 (1936) nr 9, s. 379-380; K. Jastrzębski, Synod Plenarny na Jasnej Górze, Gazeta Kościelna 44 (1937), s. 16-18 i 29-31; Po synodzie plenarnym, Prąd 31 (1936), s. 106-114; S. Biskupski, Primum Concilium Plenarium Polonicum. Anno Domini MDCCCXXXVI Czestochowiae habitum, Ateneum Kaplańskie 40 (1937), s. 483-490; S. Wójcik, Zew Chrystusowy. Uchwaly I Polskiego Synodu Plenarnego dla wiernych, Tucho 1939; I Walczewski, Rzut oka na uchwaty Pierwszego Polskiego Synodu Plenarnego, Miesięcznik Kościelny 53 (1938), s. 363-369, 402-406, 463-467; I. Walczewski, Treść i znaczenie uchwal I Polskiego Synodu Plenarnego, Poznań 1938; I Grabowski, Pierwszy synod plenarny Rzeczypospolitej Polskiej, Głos Kapłański 12 (1938), s. 5-20; S. Glaser, Znaczenie i moc obowiazujaca uchwat I Polskiego Synodu Plenarnego, Ruch Katolicki 8 (1938), s. 396-406; S. Wyszyński, Poznanie i wykonanie uchwal Synodu Planarnego szczytnym postannictwem Polskiego Katolicyzmu, Ateneum Kapłańskie 42 (1938), s. 282-286; R. Wensierski, Poznanie $i$ wykonanie uchwat Synodu Plenarnego szczytnym postannictwem polskiego katolicyzmu. Wyklad na temat nowego hasta programowego Akcji Katolickiej na rok 1938/39, Poznań 1938; Poznanie i wykonanie uchwat I-go Polskiego Synodu Plenarnego szczytnym postannictwem polskiego katolicyzmu. Referat na akademie ku czci Chrystusa Króla, Tarnów 1938; O pierwszym polskim Synodzie planarnym. Wyklad na zebranie ogólne w listopadzie 1938 r. dla KSM $i$ KSK, w grudniu 1938 r. dla KSMM i KSMZ, Tarnów 1938; B. Kominek, Polski Synod, Katowice 1939; W. Jezusek, Synod plenarny a ujednostajnienie karności kościelnej, Miesięcznik Pasterski Plocki 34 (1939), s. 31-33, 60-66, 124-127, 181-182; ks. W. Góralski, Pierwszy Synod Plenarny, Lad 6 (1988) nr 11, s. 6 i nr 12, s. 6; ks. W. Góralski, Korektury rzymskie w uchwatach pierwszego polskiego synodu plenarnego z 1936 roku, Prawo Kanoniczne 33 (1990) nr 1-2, s. 153-173.

${ }^{2}$ Akta Ogólne: Konferencja Episkopatu. Protokół Zjazdu Biskupów Polskich Warszawa w dniach 15-17 marca 1927 roku, Archiwum Kurii Diecezjalnej w Siedlcach, T. 11, k. 9 (dalej: KE, liczba podana obok oznaczenia literowego będzie wskazywać tom akt i numer karty). 
greckokatolickiego - G. Chomyszyna, sufragana gnieźnieńskiego bpa A. Laubitza. Ocena tych referatów przynagliła biskupów zebranych na konferencji w Warszawie w dniu 18 kwietnia 1928 roku do opowiedzenia się za zwołaniem nadzwyczajnej konferencji biskupów do Gniezna.

Kardynal Hlond pismem z dnia 11 czerwca 1928 roku zwołal konferencję nadzwyczajną do Gniezna na dzień 17 września 1928 roku ${ }^{3}$. W zaproszeniu Prymas wskazał tematykę mającej się odbyć konferencji. Zasadnicze tematy dotyczyć miały aktualnego stanu religijności w Polsce, duchowieństwa, parafii, kaznodziejstwa, radykalizacji społeczeństwa w aspekcie socjalnym i religijnym, zagadnienia funkcjonowania Akcji Katolickiej, postaw inteligencji i młodzieży akademickiej wobec zachodzących przemian religijności, kwestie prasy katolickiej, organizacji struktury kościelnej, stosunku do rządu i Sejmu oraz aktualnych zadań biskupów w stosunku do życia kościelnego. Tak szeroko zakreślony program konferencji miał dać asumpt do całościowej oceny sytuacji Kościoła katolickiego działającego w niepodległej Polsce, ale w jakże zmienionych warunkach po roku 1918.

Episkopat, zebrany 16 września 1928 roku w Gnieźnie, rozpoczął swe prace odbyciem rekolekcji i nabożeństwem w bazylice prymasowskiej ${ }^{4}$. Dnia 20 września Konferencja Episkopatu uchwaliła odbycie synodu krajowego i utworzenie oddzielnej komisji synodalnej z przewodniczącym kard. Hlondem, sekretarzem bpem Przeździeckim oraz biskupami Nowakiem i Szlagowskim, jako członkami tejże komisji. Jej zadanie zostało zakreślone do zebrania wniosków i postulatów od biskupów ordynariuszów oraz uporządkowanie ich według określonej tematyki. Utworzono też Komisję prawną, w skład której weszli biskupi ordynariusze: bp Szelążek i bp Przeździecki5.

KE 11. Kard. Hlond do biskupów, Poznań 11 czerwea 1928, k. 1.

${ }^{4}$ KE 11. Protokół Konferencji Episkopatu Polski, Gniezno 16-20 września 1928, k. 1. Oprócz gospodarza spotkania - Prymasa Hlonda obecni byli kard. Kakowski, arcybiskupi Szeptycki, Teodorowicz, Sapieha, Twardowski, Jalbrzykowski, Mańkowski, biskupi ordynariusze Nowak, Wałęga, Chomyszyn, Łosiński, Kocylowski, Loziński, Gall, Szelązek, Fulman, Krynicki, Przeździecki, Łukomski, Tymieniecki, Okoniewski, Kubina, Lisiecki, a także sufragani: Fischer, Owczarek, Kubicki, Komar, Michalkiewicz, Laubitz, Lakota, Toczak, Rospond, Radoński, Dominik, Szlagowski, Lisowski. Szeroko na ten temat: S. Kosiński, Prace przygotowawcze, „Seminare” 1979, s. 232-240.

${ }^{5}$ KE 12. Referat sekretarza Komisji Przygotowawczej Synodu Plenarnego w Polsce, k. 2 . 
W dniu 29 września 1928 roku kard. Hlond wystosowal prośbę do biskupów ordynariuszów obrządku łacińskiego o sformułowanie uwag uzupełniających do wygłoszonych referatów. W liście tym po raz pierwszy pojawiła się propozycja odbycia synodu w miesiącach jesiennych 1931 roku. Dnia 21 października 1929 roku kard. Kakowski, pisząc do kard. Hlonda, zwraca uwagę iż celem synodu jest danie biskupom zasadniczych wytycznych dotyczących jednolitego zewnętrznego występowania, stworzenie partykularnego prawa obowiązującego wszystkich biskupów z „mocą prawa”, a nie, jak do tej pory, z „mocą moralną”. Nadto uchwaly synodu ogólnopolskiego bylyby podstawą dla synodów diecezjalnych i prowincjalnych ${ }^{6}$. W dalszej części listu Autor wskazał na kanon 290, który nakreślał przedmiot obrad synodów plenarnych ${ }^{7}$.

Odzewem, na prośbę kard. Hlonda o nadsyłanie uwag, były pisemne wypowiedzi kard. Kakowskiego, bpa łódzkiego, bpa łuckiego, bpa plockiego, bpa kujawsko-kaliskiego, bpa kieleckiego, bpa podlaskiego.

Dnia 22 października 1930 roku prymas zwrócił się do biskupów $\mathrm{z}$ tą samą prośbą po raz drugi. W piśmie podkreślał konieczność ujęcia tyko tych spraw, które domagają się uregulowania prawem partykularnym na terenie całej Polski. Dalsze odpowiedzi na przynaglenia z dnia 22 października 1930 roku nadeszły od kard. Prymasa, bpa płockiego, bpa przemyskiego, kard. Kakowskiego, bpa łomżyńskiego, bpa katowickiego, bpa pińskiego, sandomierskiego. Ogółem nadeszło 11 odpowiedzi. Posłużyły one do uformowania referatu, który został przedstawiony do dyskusji na posiedzeniu Komisji przygotowawczej dnia 19 marca 1931 roku w Poznaniu. Referat przygotował sekretarz Komisji - bp Przeździecki.

Tego samego dnia na ręce bpa Szeptyckiego Prymas wystosował prośbę skierowaną do biskupów obrządku greckokatolickiego o przygotowanie wniosków na zbliżający się synod. Tenże, listem z dnia 4 stycznia, dał na nią odpowiedź pełną wątpliwości czy bisku-

\footnotetext{
${ }^{6} \mathrm{P}$. Kałwa, Rzut oka na prace przygotowawcze synodu plenarnego, List kard. Kakowskiego, Akta synodu I plenarnego - korespondencja od 12.02.1936 do 5.04.1939, s. 1-2, Archiwum Kurii Siedleckiej (dalej: AKS).

${ }^{7}$ "Patres in Cocilio plenario vel provinciali congregati studiose inquirant ac decernant quae ad fide incrementum, ad moderandos mores, ad corrigendos abusus, ad controversias componendas, ad unam eandemque disciplinam servandam vel inducendam, opportuna fore pro suo cuiusque territorio videantur".
} 
pi obrządku greckokatolickiego mogą brać udział w obradach synodu obrządku łacińskiego ${ }^{8}$.

Jak nierealny byl postulat zwołania synodu na jesień roku 1931 świadczy fakt, iż Komisja przygotowawcza swoje pierwsze posiedzenie odbyła dopiero 19 marca 1931 roku w Poznaniu, a drugie 26 sierpnia 1931 roku w Brzozowie w letniej rezydencji bpa przemyskiego. Celem wspomnianej Komisji było rozstrzygnięcie kwestii ogólnych synodu i stanowiących zręby dalszej jego struktury i działalności. Stąd na pierwszym posiedzeniu orzeczono, iż w sprawie udziału w obradach synodalnych biskupów obrządków wschodnich Prymas zwróci się o rozstrzygnięcie tej kwestii do Stolicy Apostolskiej. Kolejnym problemem, wymagającym odpowiedzi było to, co ma być przedmiotem obrad synodalnych. Odpowiedź zawierała się w przytoczonym kanonie 290. Odnośnie do postawionego pytania o wzorzec - zasadę podziału materiału synodalnego - zdecydowano, iż takim wzorcem ma być podział zastosowany w Kodeksie Prawa Kanonicznego. Uchwały synodu powinny, jak przystało na synod partykularny, uszczegóławiać rozporządzenia ogólne. Ujawnił się też problem, jak rozdzielać wnioski i materiały nadsyłane na synod. Kard. Hlond zaproponował rozdzielanie ich na poszczególne metropolie, co w toku dyskusji na drugim posiedzeniu upadło ze względu na powołanie Komisji specjalnych, które zajęly się rozpatrywaniem poszczególnych kwestii. Postanowiono również, iż do 15 lipca 1931 roku ordynariusze powinni zapoznać się i dokonać uwag a następnie należy nanieść poprawki w zebranych od nich materiale wstępnym. Uwagi te miały być opracowane przez sekretarza Komisji ogólnej, która 2 września obradować miała w Przemyślu w celu opracowania programu narad i uchwał synodu plenarnego. Program ów miał być w pierwszej połowie września przesłany ordynariuszom, którzy mieli nad nim dyskutować na Zjeździe Episkopatu w październiku 1931 w Częstochowie. Wreszcie zdecydowano, iż uwagi nadsylane przez biskupów poza terminem wykorzystane będą do uzupełnien, ewentualnie poprawek, w tekście projektów ustaw. 25 marca 1931 roku rozesłano protokół posiedzenia Komisji przygotowawczej z 19 marca tegoż roku. Dołączono również referat bpa Przeździeckiego. Odpowiedzią były pisma arcybiskupa wileńskiego, bpa kieleckiego, bpa katowickiego i sandomierskiego.

\footnotetext{
${ }^{8} \mathrm{KE} 12, \mathrm{k} .1-3$.
} 
Na drugim posiedzeniu, 26 sierpnia 1931 roku, potwierdzono słuszność podziału uchwał synodalnych według układu kodeksowego. Poddano również pod dyskusję referat bpa Przeździeckiego. Postanowiono, jako niepotrzebny, usunać dział de fide, a jego zagadnienia umieścić w dziale de rebus - de magisterio ecclesiastico. Przyjęto program synodu i podział materiału. Powolano Komisję ogólną i specjalne. Wyłonienie tych dwóch komisji miało kapitalne znaczenie dla przebiegu prac synodu. Komisje specjalne miały przygotować projekty uchwał w języku polskim i lacińskim po szerokich konsultacjach $\mathrm{z}$ ekspertami w danej dziedzinie. Chodziło o możliwie najbardziej dogłębne spojrzenie na problemy Kościoła w Polsce. Sformułowane przez Komisje specjalne uchwały miały być przesyłane do Komisji ogólnej, która wtórnie je badała i ustalała ostateczne ich brzmienie. Komisja ogólna miała się też zająć stroną techniczną przygotowania synodu. W jej skład weszli: przewodniczący synodu, metropolici, przewodniczący Komisji specjalnych i sekretarz - bp Przeździecki. Sprawami Akcji Katolickiej, na wniosek bpa katowickiego, miała się zająć Komisja de laicis ${ }^{9}$. Działalność Komisji specjalnych miała się zakończyć z dniem 1 maja 1932 roku $^{10}$. Nadto, biskupi ułożyli plan najbliższych spotkań Episkopatu; najbliższy zjazd biskupów miał odbyć się 6 października 1931 roku na Jasnej Górze. Ostatnią proceduralną sprawą było ustalenie miesięcznej składki na potrzeby przygotowania synodu. Kolejny raz poruszono konieczność udziału w pracach synodalnych biskupów obrządków wschodnich, na potwierdzenie czego przesłano protokoły posiedzeń Komisji przygotowawczej z 19 marca i 26 sierpnia oraz referat bpa Przeździeckiego arcybiskupowi lwowskiemu obrządku ormiańskiego, biskupom stanisławowskiemu i przemyskiemu obrządku greckokatolickiego ${ }^{11}$. Nie pierwszy raz określono nowy termin odbycia synodu, tym razem wskazano drugie półrocze 1933 roku. Miejscem obrad obrano Gniezno i Warszawę.

Komisja Przygotowawcza, po wypełnieniu swego zadania, uległa rozwiązaniu dnia 26 sierpnia 1931 roku.

\footnotetext{
${ }^{9}$ P. Kałwa, Rzut oka ..., s. 2-4; także: S. Kosiński, Synod plenarny polski w 1936 roku, „Studia Claromontana” 8 (1987), s. 11-14.

${ }^{10} \mathrm{KE} 12$, k. 20.

${ }^{11} \mathrm{KE} 12$, k. 35-36.
} 


\section{Ankieta skierowana do biskupów diecezjalnych}

Drugi okres przygotowań do synodu rozpoczęty został na Konferencji Plenarnej Episkopatu na Jasnej Górze odbytej w dniach 6-8 października 1931 roku. Wzięło w niej udział 34 biskupów (23 ordynariuszów i 11 sufraganów), w tym obrządków wschodnich: arcbp Teodorowicz i bp Kocyłowski. Konferencji przewodniczyl kard. Kakowski, a rozpoczął ją Mszą św. Arcbp Nowowiejski. W piątym punkcie obrad znalazla się sprawa synodu plenarnego. Wyniki prac oraz postanowienia Komisji przygotowawczej zreferowane przez bpa Przeździeckiego - sekretarza Komisji - przyjęto. Konferencja uchwaliła, iż Komisje specjalne mają rozpocząc swą pracę po Zjeździe biskupów, a zakończyć ją do 1 maja 1932 roku. Przewodniczący i sekretarz każdej Komisji mieli przesłać protokoły narad i opracowany dział uchwał synodalnych powierzony Komisji w formie kanonów i instrukcji do dnia 15 maja 1932 roku. Następnie Komisja ogólna miała rozpatrywać nadesłany materiał do dnia 20 czerwca 1932 roku, tak by ten odcinek pracy mógł być zakończony do dnia 1 listopada 1932 roku. Na miesiąc luty 1933 roku przewidziano zwołanie przygotowawczego zebrania ogólnego przyszłego synodu plenarnego. Cechą charakterystyczną tej konferencji w sprawie synodu było to, że skład uczestników został rozszerzony o biskupów obrządków wschodnich ${ }^{12}$. Decyzja powolania Komisji ogólnej i komisji specjalnych uwieńczona została wyznaczeniem składu osobowego poszczególnych Komisji ${ }^{13}$. Zauważalna jest re-

${ }^{12}$ KE 13, Komisja plenarna Episkopatu Polski w Częstochowie 6-8 październik 1931, k. 6.

${ }^{13}$ 1. Komisja ogólna: przewodniczący kard. Kakowski, sekretarz - bp Przeździecki, członkowie - wszyscy metropolici i przewodniczacy Komisji specjalnych. 2. Komisja dla Norm Generalnych: kard. Hlond, bp Dominik, bpi: Wałęga, Łoziński, Tymieniecki, Kubina, Radoński. 3. Komisja dla Duchowncyh w ogólności i w szczególności: kard. Sapieha, bp Sokołowski, bpi: Szeptycki, Teodorowicz, Chomyszyn, Przeździecki, Gall, Łukomski, Okoniewski, Jasiński, Tomczak. 4. Komisja dla Zakonników: bpi: Nowak, Lisowski, kard. Hlond, Kocyłowski, Łoziński, Szlagowski. 5. Komisja dla Katolików Swieckich: arcbp Jałbrzykowski, bpi: Wetmański, Sapieha, Teodorowicz, Chomyszyn, Jasiński, Tymieniecki, Kubina, Adamski. 6. Komisja dla Sakramentó: bpi: Szelążek, Rospond, Wałęga, Fulman, Gall, Okoniewski, Radoński, Owczarek, Latyszewski. 7. Komisja dla Miejsc i Czasów Świętych oraz Kultu Bożego: bpi: Nowowiejski, Komar, Nowak, Łoziński, Łukomski, Okoniewski, Jasiński, Dymek. 8. Komisja dla Nauczania Kościelnego: bpi: Lukomski, Latyszewski, Teodorowicz, Kocyłowski, Fulman, Szelążek, Tymieniecki, Kubina, Kubicki, Michalkiewicz, Barda. 9. Komisja dla Beneficjów i Dóbr Kościelnych: arcbp Twardowski, bpi: Dembek, Szeptycki, Fulman, Radoński, Adamski, 
dukcja liczby komisji z proponowanych 14 do 10 . Konferencja ustaliła również, iż fundusz synodalny zostanie wzmocniony obcięciem subwencji (20\%) na Katolicką Agencję Prasową ${ }^{14}$. Zdecydowano o kolejnym przesunięciu terminu odbycia synodu na rok 1933 oraz wyznaczono Częstochowę na miejsce jego obrad.

Na posiedzeniu Komisji ogólnej 7 października, podczas wspomnianej konferencji, do załatwiania spraw bieżących wyłoniono Komitet Wykonawczy Komisji ogólnej w składzie: arcbp warszawski, arcbp gnieźnieńsko-poznański, arcbp krakowski, bp podlaski. Siedzibą Komitetu Wykonawczego obrano Biuro Episkopatu Polski ${ }^{15}$.

Biskup Przeździecki 11 czerwca 1932 roku zwrócil się do przewodniczących poszczególnych komisji, by do 15 sierpnia 1932 roku nadesłali wyniki prac swoich komisji ${ }^{16}$. Kolejne konferencje odbyte w Gnieźnie (19-29 wrzesień 1932 r.) oraz w Warszawie (22 listopada 1932 r.) wykazały nierealność narzuconego sobie terminu odbycia synodu. Bp Przeździecki znów usilnie zwracał się do biskupów o nadsyłanie wniosków, tym razem w terminie do 1 kwietnia 1933 roku ${ }^{17}$. Niestety, ze względu na śmierć bpa Anatola Nowaka w kwietniu 1933 roku, po którym przewodniczenie w Komisji dla Spraw Zakonników przejął kard. Hlond oraz ze względu na opieszałość w dostarczaniu materiałów przez bpa Walczykiewicza, kolejny raz nie doszło do zrealizowania planów.

W odpowiedzi na prośbę bpa Przeździeckiego zaczęly naplywać protokoły narad niektórych Komisji oraz pierwsze projekty uchwał synodalnych.

\section{Podział prac według tematów w Komisjach specjalnych}

Komisja dla Norm Generalnych swoją pracę rozpoczęla wyznaczeniem tematów, którymi się miała zająć. Temat pierwszy „Stosunek uchwał synodalnych do prawa powszechnego Kościoła oraz do

Laubitz. 10. Komisja dla Spraw Sądowych i Kanonizacyjnych: bpi: Tymieniecki, Walczykiewicz, Sapieha, Szelążek, Okoniewski, Jełowicki, Łakota, Rospond, Buczko - KE 13, k. 6-7; także Archiwum Kurii Siedleckiej (dalej: AKS), Projekty ustaw synodalnych 1932-1933, część 1 karta 7, s. 4-5.

${ }^{14}$ Założona w roku 1927. Jej pierwszym dyrektorem byl późniejszy biskup polowy ks. J. Gawlina.

${ }^{15}$ AKS, cz. 1, k. 4, Protokół posiedzenia ogólnej komisji synodu plenarnego dnia 7 października 1931 roku w Częstochowie.

${ }^{16}$ AKS, jw., cz. 1, k. 5.

${ }^{17} \mathrm{KE} 13$, k. 7. 
praw i zwyczajów lokalnych poszczególnych diecezji polskich" miał opracować kard. Kakowski. Tenże biskup miał opracować również drugi temat: „Sposób promulgacji uchwał synodalnych”. Zadaniem biskupa kujawsko-kaliskiego były sprawy konkordatowe. Kolejne dwa tematy: "Katolicy obrządku wschodniego w diecezji według Konkordatu” oraz „Consuetudo w stosunku do uchwal synodu plenarnego", miał opracować biskup podlaski ${ }^{18}$. Zadaniem Prymasa było opracowanie tematu „Stosunek uchwał synodu plenarnego do synodów prowincjonalnych”. „Zbiór praw diecezjalnych”, kolejny temat, miał opracować biskup plocki. Do zadań arcybiskupa wileńskiego należało opracowanie dwóch ostatnich tematów „Uzgodnienia praw partykularnych” oraz „Ulegalizowanie w Stolicy Apostolskiej zwyczajów dla całego kraju" ${ }^{19}$. W toku dyskusji nad poszczególnymi referatami biskupi doszli do sformułowania pierwszych propozycji w zakresie działu Normae generales. Zostały przedstawione dwie redakcje; druga, końcowa redakcja zamykająca dwuletni okres pracy tej Komisji, obejmowała 10 artykułów. Artykuł pierwszy proponowal, iż ustawy synodalne zaczną obowiązywać w rok od ich zatwierdzenia przez Stolicę Apostolską. W artykule drugim przewidywano, że promulgacja ustaw nastąpi najpóźniej w sześć miesięcy po ich zatwierdzeniu przez Stolicę Apostolską poprzez ogloszenie ich w pismach urzędowych poszczególnych diecezji. W artykule trzecim zamieszczono dyspozycję by biskupi w ciągu sześciu miesięcy od promulgacji ogłosili przepisy prawa diecezjalnego i zwyczajów diecezjalnych zmienionych lub zniesionych przez synod plenarny. Artykul czwarty przewidywał zniesienie uchwaly z czasów przedrozbiorowych Synodów Prowincjalnych Metropolii Gnieźnieńskiej. Podobnie zniesione miały być prawa i zwyczaje partykularne niezgodne z przepisami Synodu, co zostało umieszczone w artykule piątym. W odróżnieniu od redakcji pierwszej, w redakcji drugiej zamieszczono artykul dotyczacy zachowania zwyczajów niepamiętnych lub stuletnich zgodnie $\mathrm{z}$ uznaniem biskupa, jeśli Synod wyraźnie ich nie zniósł. Siódmy artykuł przewidywał, że nie można będzie wydawać praw niezgodnych z postanowieniami Synodu, po zatwierdzeniu ustaw synodalnych przez Stolicę Apostolską. W stosunku do pierwszej redakcji, dodano artykuł ósmy

\footnotetext{
${ }^{18}$ AKS, Projekty ustaw synodalnych. Rok 1932-33, cz. 2, k. 4.

${ }^{19}$ Jw., cz. 2, k. 9.
} 
o zakazie wprowadzania zwyczajów przeciwnych przepisom Synodu. Artykul dziewiąty wprowadzal zakaz dyspensowania od ustaw synodalnych, chyba że w pojedynczych przypadkach i dla słusznej przyczyny. Projekt ostatniego - dziesiątego artykulu, dodanego w stosunku do pierwszego projektu, wskazywal plenarną Konferencję Episkopatu Polski, jako uprawnioną do autentycznego interpretowania uchwał synodalnych. W drugiej redakcji zabrakło uchwał, zawartych w pierwszej, dotyczących ich obowiązywalności oraz kompetencji ordynariuszów w stosunku do duchownych i wiernych nie posiadających ordynariusza swego obrządku. Pierwsza redakcja przewidywala, ze uchwały dotyczą duchownych i wiernych obrządków wschodnich tylko w sprawach ogólnych z wykluczeniem rozstrzygnięć odnośnie do kwestii liturgicznych i specjalnych praw tych obrządków. Zabrakło również dyspozycji, iż ordynariusze obrządku lacińskiego bez pozwolenia Stolicy Apostolskiej nie mają prawa zmieniać przepisów w sprawach poszczególnych obrządków ${ }^{20}$.

Prymas przesłał oba projekty ustaw na ręce kard. Kakowskiego dnia 28 maja 1932 roku, a 28 października tegoż roku na ręce bpa Przeździeckiego ${ }^{21}$.

Pracę Komisji De clericis przedstawiono w protokole dołączonym do projektów statutów. Dnia 27 października 1931 roku arcbp Sapieha rozesłał do biskupów - członków Komisji - prośbę o zapoznanie się z działem Kodeksu dotyczącym tematu oraz zebrania postanowień, jakie by się na synod nadawały ${ }^{22}$. Przewodniczący Komisji 30 grudnia 1931 roku przesłał biskupom zaproszenie na posiedzenie wyznaczone na dzień 12 stycznia 1932 roku do siedziby arcbpa Teodorowicza we Lwowie ${ }^{23}$. Na posiedzeniu tym ustalono tematy, które miały się stać podstawą dyskusji w gronie komisji złożonej z kilku księży pod przewodnictwem ks. dr Adama Gerstmanna - rektora Uniwersytetu Lwowskiego. Posiedzenie takie odbyło się 26 czerwca 1932 roku. Wnioski tej komisji stały się podstawą dyskusji biskupów - członków Komisji De clericis ${ }^{24}$. Trzy kolejne redakcje, posługujące się układem kodeksowym, zastosowały podział materiału synodal-

\footnotetext{
${ }^{20} \mathrm{Jw}$, , cz. 2, k. 6.

${ }^{21}$ JW., cz. 2, k. 10.

${ }^{22}$ Jw., cz. 3, k. 1-2.

${ }^{23}$ Jw., cz. 3, k. 7.

${ }^{24}$ Jw., cz. 3, k. 8.
} 
nego na działy De clericis in genere i De clericis in specie. Redakcja pierwsza obejmowała 36 artykułów, druga - 19, a trzecia - 36. Poszczególne uchwały dotyczyly następujących zagadnień in genere:

- obowiązku uświęcania się (kan. 125), do którego zaliczono konieczność czytania Pisma św., książek o treści religijnej, przynależność do pobożnych stowarzyszeń kapłańskich oraz nakaz odbycia co trzy lata rekolekcji (zgodnie z dyspozycją kan. 126 CIC). W drugiej redakcji dodano przykłady wyżej wspomnianych stowarzyszeń: Unio Apostolica, Assotiatio Perseverentiae ${ }^{25}$,

- ścisłego przestrzegania dyspozycji kan. 129-131, tzn. doskonalenia się w naukach teologicznych i tych świeckich, które są potrzebne do należytego spełniania duszpasterstwa oraz udział w kongregacjach dekanalnych, kursach duszpasterskich, katechetycznych, liturgicznych i społecznych, a także czytanie czasopism teologicznych i pastoralnych ${ }^{26}$,

- egzaminu dopuszczającego do konkursu na beneficja (kan. $130)$; brak jest natomiast tej dyspozycji w drugiej redakcji $\mathbf{i}^{27}$,

- powstawania domów dla kapłanów nie mieszkających na plebaniach. Zalecono by kapłani, którzy nie pracują w parafii mieszkali na plebaniach ${ }^{28}$, polecenia powolania funduszu emerytalnego i budowania domu emerytów ${ }^{29}$, polecenia tworzenia domów wypoczynkowych i sanatoriów dla księży ${ }^{30}$,

- zalecono kapłanom posiadanie schludnych, skromnych i nie gorszących mieszkań oraz skromnych przyjęć z okazji odpustów i innych uroczystości ${ }^{31}$,

- zakazu obarczania się rodziną (zgodnie z dyspozycją kan. 133 CIC) oraz zakaz wtrącania się rodziny w sprawy parafialne ${ }^{32}$,

- nakazu regularnego opłacania służby kościelnej ${ }^{33}$, określenia minimalnego wieku kobiet zajmujących się gospodarstwem plebanijnym (40 lat) ${ }^{34}$,

\footnotetext{
${ }^{25}$ Jw., cz. 3, k. 5 pkt 1,6 pkt 1,10 pkt 1.

${ }^{26}$ Jw., cz. 3, k. 5, p. 2, 3; k. 6 p. 2; k. 10, p. 2, 3.

${ }^{27}$ Jw., cz. 3 , k. 5 , p. 4 ; k. 10 , p. 4.

${ }^{28}$ Jw., cz. 3 , k. 5, p. 5; k. 6, p. 3 ; k. 10 , p. 5.

${ }^{29}$ Jw., cz. 3, k. 5, p. 14; k. 10, p. 14.

${ }^{30}$ Jw., cz. 3, k. 5, p. 15; k. 10, p. 15.

${ }^{31}$ Jw., cz. 3, k. 5, p. 6; k. 10, p. 6.

${ }^{32}$ Jw., cz. 3 , k. 5 , p. 7 ; k. 6 , p. 5 ; k. 10 , p. $7 \$ 1$.

${ }^{33}$ Jw., cz. 3 , k. 5 , p. 7 ; k. 6 , p. 4 ; k. 10 , p. $7 \$ 2$.

${ }^{34}$ Jw., cz. 3, k. 6, p. 4.
} 
- polecenia czynnego udziału kapłanów w organizacjach oświatowych, charytatywnych, społecznych, tak by nie powodowało to zaniedbań obowiązków stanu kapłańskiego ${ }^{35}$, zakazu przyjmowania stanowisk kierowniczych w stronnictwach politycznych o niejasnym stosunku do Kościoła ${ }^{36}$ oraz publicznych mandatów stałych lub czasowych $^{37}$, zakazu nabywania nieruchomości bez pozwolenia ordynariu$\mathrm{sza}^{38}$, zakazu podpisywania weksli i poręczenia za innych (kan. 137) ${ }^{39}$,

- zakazu ubierania się po świecku i konieczności noszenia koloratki oraz tonsury (kan. 136) ${ }^{40}$.

W dziale De clericis in specie umieszczono następujące dyspozycje:

- konieczność odprawiania nabożeństwa w niedzielę po rocznicy koronacji Papieża dla ożywienia przywiązania do Ojca św. ${ }^{41}$, a także podobne nabożeństwa w rocznicę konsekracji biskupa diecezjalnego ${ }^{42}$,

- powinność odbywania co roku konferencji biskupów ordynariuszów ${ }^{43}$, a zgodnie z brzmieniem kanonów 343-346 zalecono odbywanie wizytacji biskupich ${ }^{44}$ oraz urządzenia muzeum kościelnego w każdej diecezjiit

- podkreślono obowiązek zdawania sprawozdań przez dziekanów ze stanu ich dekanatów (kan. 449) ${ }^{46}$; do uzyskania beneficjum proboszczowskiego kapłani winni zdać egzamin (kan. 459) ${ }^{47}$, polecono jednocześnie by parafiami zarządzali proboszczowie, a nie administratorzy ${ }^{48}$. Polecono ustanowienie stalych oplat za czynności duszpasterskie (iura stolae) z zastrzeżeniem unikania pozorów chciwości $^{49}$; nie można domagać się datków przy okazji kolędy ${ }^{50}$, a biednym należy udzielać sakramenty za darmo,

\footnotetext{
${ }^{35}$ Jw., cz. 3, k. 5, p. 12; k. 10, p. 12.

${ }^{36}$ Jw., cz. 3, k. 5, p. 11; k. 10, p. 11.

${ }^{37}$ Jw., cz. 3, k. 6, p. 7.

${ }^{38}$ Jw., cz. 3, k. 5, p. 10; k. 6, p. 6; k. 10, p. 10.

${ }^{39}$ Jw., cz. 3, k. 5, p. 10; k. 10, p. 10.

${ }^{40}$ Jw., cz. 3, k. 5, p. 8; k. 10 , p. 8.

${ }^{41}$ Jw., cz. 3, k. 5, p. 17; k. 10, p. 17.

${ }_{42}$ Jw., cz. 3, k. 5, p. 18 ; k. 10, p. 18.

${ }^{43}$ Jw., cz. 3, k. 5, p. 19 ; k. 6, p. 10; k. 10, p. 19.

${ }_{44}^{44}$ Jw., cz. 3, k. 5, p. 20; k. 10, p. 19.

${ }^{45}$ Jw., cz. 3, k. 5, p. 21; k. 10, p. 21.

${ }^{46}$ Jw., cz. 3, k. 5, p. 22; k. 10, p. 22.

${ }^{47}$ Jw., cz. 3, k. 5, p. 24; k. 10, p. 24.

${ }^{48}$ Jw., cz. 3, k. 5, p. 23; k. 10, p. 23.

${ }^{49}$ Jw., cz. 3 , k. 5, p. 26; k., 6, p. 15 ; k. 10 , p. 26.

${ }^{50}$ Jw., cz. 3, k. 5, p. 25; k. 6, p. 14; k. 10, p. 25.
} 
- wskazano na obowiązek proboszczów zapewnienia wikariuszowi mieszkania pozostawiając sprawę iura stolae oraz opłat za wikt

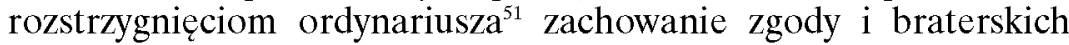
stosunków pomiędzy kapłanami ${ }^{52}$, ścisła wspólpraca kapelanów wojskowych $\mathrm{z}$ parafialnymi ${ }^{53}$, powinność zakonów wspomagania duszpasterstwa parafialnego ${ }^{54}$, wspólne konferencje wzmacniające jedność kapłańską ${ }^{55}$, to szczegółowe powinności kapłanów,

- proboszczowie winni wykazać się gorliwą pracą w Akcji Katolickiej i opieką nad stowarzyszeniami katolickimi ${ }^{56}$, a te winny zachować ścisłą więź z parafią ${ }^{57}$. W ramach Konferencji Episkopatu winny być powolane komisje dla spraw szkolnych, Akcji Katolickiej, dobroczynności, dla spraw prasowych, Uniwersytetu Katolickiego, dla różnych obrządków i dla spraw prawnych ${ }^{58}$, natomiast dla spraw związanych $\mathrm{z}$ wykonaniem Konkordatu powołana została Komisja Papieska, ustanowiona przez Stolicę Apostolską ${ }^{59}$.

W drugiej redakcji bardziej zwrócono uwagę na działalność Konferencji Episkopatu i podziału pracy w jej ramach, co wyrażało się propozycją powołania komisji zajmujących się poszczególnymi zagadnieniami życia kościelnego.

Komisja synodalna De religiosis, uformowawszy krótki projekt, przesłała go bpowi Przeździeckiemu bez protokołu zebrań. Uformowano trzy statuty ${ }^{60}$.

Prace Komisji De laicis rozpoczęly się z momentem wystosowania do bpa Przeździeckiego prośby z dnia 7 października 1931 roku o sprecyzowanie tematów, jakimi miała się zająć. Proszono o odpo-

\footnotetext{
${ }^{51}$ Jw., cz. 3, k. 5, p. 27; k. 6, p. 16; k. 10, p. 27.

${ }^{52}$ Jw., cz. 3, k. 5, p. 28; k. 10, p. 28.

${ }^{53}$ Jw., cz. 3, k. 5, p. 31; k. 6, p. 17; k. 10, p. 31.

${ }^{54}$ Jw., cz. 3, k. 5, p. 32; k. 10 , p. 32.

${ }^{55}$ Jw., cz. 3, k. 5, p. 33; k. 6, p. 18; k. 10, p. 33.

${ }^{56}$ Jw., cz. 3 , k. 5, p. $36 ;$ k. 6 , p. $16 ;$ k. 10 , p. 36.

${ }^{57}$ Jw., cz. 3, k. 5, p. 35 ; k. 10, p. 35.

${ }^{58} \mathrm{Jw}$, cz. 3, k. 6 , p. 12.

${ }^{59}$ Jw., cz. 3, k. 6, p. 13.
}

${ }^{60}$ Brzmiały one: 1. „Aby podnieść znaczenie zakonów dla życia religijnego Synod Krajowy zaleca duchowieństwu świeckiemu i regularnemu, by zachowywały wzajemny stosunek oparty na szacunku i zaufaniu i by dążyły do zgodnej współpracy w myśl intencji Kościoła i ducha poszczególnego zakonu”, 2. „Wszyscy zakonnicy będą przed święceniami składali egzaminy przewidziane w kanonach 996 i 997”, 3. „Na równi z klerem świeckim będą kapłani składali egzaminy przepisane w Diecezjach celem uzyskania jurysdykcji do słuchania spowiedzi i zezwolenia na wygłaszanie kazań". 
wiedź do dnia 25 października. Odpowiedź wysłano 14 października na ręce arcbpa Jałbrzykowskiego; wystosował ją biskup Sokolowski. Podał cztery zasadnicze tematy:

- bractwa - należy opracować wzorcowy statut, który mógłby przyczyniać się do ożywiania działalności bractw, ewentualnie rozpatrzenie projektu bpa śląskiego, który wszystkie bractwa chciałby widzieć jako powiązane $\mathrm{w}$ działalności przygotowującej do Akcji Katolickiej,

- psałterzyści obrządku wschodniego - polecono wydać regulamin ogólny. Biskup Sokołowski przesłał wzór regulaminu diecezjalnego,

- organiści - stworzenie ogólnego regulaminu służby kościelnej, wzorów umów z organistą i służbą kościelną uznano za jedną z ważniejszych spraw. Wzory zaczerpnięto z przepisów Synodu Diecezji Podlaskiej,

- stosunek stowarzyszeń religijnych do prawa państwowego (bractwa jako jednostki prawne kościelne).

Efektem prac komisji stały się dwa projekty statutów wysłanych przez arcbpa Jałbrzykowskiego w dniu 26 czerwca 1932 roku do sekretarza Komisji ogólnej ${ }^{61}$. Wraz ze statutami przesłano protokól obrad tej komisji, podpisany przez arcbpa Jałbrzykowskiego, a także biskupów Lisowskiego, Dymka i Wetmańskiego ${ }^{62}$. Dnia 1 grudnia 1933 roku komisja przyjęła drugi, liczący 42 statuty projekt i przesłała go do Komisji ogólnej. Biskupi porzucili myśl rozstrzygania spraw śpiewu kościelnego, organistów oraz służby kościelnej. Tematy te zostały przesunięte do Komisji De cultu divino ${ }^{63}$. Arcbp Jałbrzykowski wysłał z Wilna dnia 23 grudnia 1933 roku trzeci projekt zredagowany w języku łacińskim, liczący 81 paragrafów. Ten ostatni, prywatny projekt został odrzucony ${ }^{64}$.

Projekt pierwszy dzielił się na części:

- Kto jest świeckim i jakie jest jego stanowisko w Kościele (punkty 1-2),

- Obowiązki pozytywne (3-12),

- Obowiązki negatywne (13-20),

\footnotetext{
${ }^{61}$ AKS, Projekty ustaw synodalnych. Rok 1932-33, cz. 5, k. 1-2.

${ }^{62}$ Jw., cz. 5, k. 7.

${ }^{63} \mathrm{Jw} .$, cz. 5, k. 8.

${ }^{64} \mathrm{Jw} .$, cz. 5, k. 12-14.
} 
- O organizacjach wie rnych (21-23),

- Organizacje religijno-kościelne (24-27),

- Akcja Katolicka (28-33),

- Inne organizacje spoleczne (34-43).

W punkcie pierwszym odnajdujemy definicję pojęcia: „wierni” ${ }^{65}$. Do obowiązków pozytywnych zaliczono: 1. poranna i wieczorna modlitwa połączona $\mathrm{z}$ rachunkiem sumienia. Zalecono wspólne odmawianie modlitw w rodzinie, 2 . uczęszczanie na msze św. w niedziele i święta. Zalecono udzial w nieszporach oraz czytanie ksiązek religijnych, 3. trzykrotne w ciągu dnia odmawianie modlitw Anioł Pański, 4. pozdrawianie się słowami: „Niech będzie pochwalony...", 5. oddawanie czci Bogu przy przechodzeniu koło kościoła, krzyży, 6 . wyznawanie wiary w życiu prywatnym, towarzyskim i publicznym, 7. szerzenie w życiu towarzyskim i społecznym opinii katolickiej dotyczącej cudzołóstwa, konkubinatów i rozwodów oraz unikanie łamiących w tym względzie prawa Boże i kościelne, jak też unikanie kontaktów z żyjącymi w nieprawnych związkach, 8. głosowanie podczas wyborów, 9. utrzymywanie kościola, duchowieństwa i służby kościelnej. W drugiej częśsi tego projektu podano obowiązki negatywne: 1 . zabroniono surowo uczęszczanie na niemoralne i przeciwne wierze odczyty, przedstawienia teatralne i kinowe, 2. wskazano na odpowiedzialność kobiet za czystość i skromność w rodzinie i społeczeństwie, 3. uwypuklono odpowiedzialność rodziców za ubiór ich córek, 4. wyrażono zakaz nieskromnego ubioru w kościele, 5. zakaz nowoczesnych tańców, 6. potępiono wspólne plaże dla kobiet i mężczyzn, 7. zalecono powstrzymywanie się od uczęszczania do domów gry hazardowej, 8. wyrażono obowiązek dzieci opieki nad rodzicami i szacunku dla nich.

Kolejna część projektu dotyczyła organizacji wiernych. Podstawową organizacją wiernych jest parafia, a ich powinnością udzial w stowarzyszeniach katolickich. Biskupi wyróżnili trzy rodzaje organizacji wiernych: a) religijno-kościelne (trzecie zakony, bractwa, związki pobożne), b) Akcja Katolicka, c) spoleczne. Przynależność do tych organizacji służy uświadomieniu religijnemu i pogłębieniu życia wewnętrznego. Biskupi wymieniają całą gamę organizacji: Stowarzyszenie Najświętszego Sakramentu i Nauczania Chrześci-

${ }^{65}$ Jw., cz. 5, k. 5. 
jańskiego, Trzeci Zakon św. Franciszka, Bractwa Różańcowe, Szkaplerz, Sodalicje Mariańskie, Dzieła Misyjne: Dziecięctwa Jezusowego, Rozkrzewiania Wiary i św. Piotra Apostoła, Bractwa wstrzemięźliwości oraz inne. Wszystkie organizacje na terenie diecezji tworzą związek diecezjalny, kierowany przez dyrektora zgodnie ze statutem.

Część czwarta projektu dotyczyła Akcji Katolickiej. Uwyraźniony tu został zamysł biskupów, by wszystkie wcześniej wymienione organizacje były przygotowaniem do działania w ramach Akcji Katolickiej - wprawiając się do apostolstwa świeckich. Akcja Katolicka powstała dla obrony zasad religii i moralności, dla rozwoju akcji społecznej działającej ponad partiami politycznymi ku odnowieniu życia katolickiego w rodzinach i spoleczeństwie. Struktura organizacyjna Akcji Katolickiej była uformowana trójstopniowo: w parafiach - Stowarzyszenie, w diecezji - Związek, w kraju - Zjednoczenie. Pracą Akcji Katolickiej w parafii kierować miał zarząd parafialny, w diecezji - diecezjalny instytut, a w kraju - naczelny instytut. Ku zapewnieniu prężności działania w każdej parafii powinien istnieć dom katolicki.

Końcowa, piąta część pierwszego projektu ukazywała możliwości realizowania chrześcijańskiego modelu życia poprzez udział wiernych w pracach Katolickiego Koła Abstynentów (wspomagającego bractwa trzeźwościowe), w parafialnym wydziale Akcji Charytatywnej, które w swych strukturach są upodobnione do Akcji Katolickiej i jej organizacyjnie podporządkowane. Końcowe artykuły traktowały o organistach, nakazując im przynależność do kolegium organistów-chórmistrzów.

Drugi projekt liczył lącznie 42 artykuły zgrupowane w pięciu rozdziałach:

I - Pojęcie i prawa osób świeckich,

II - Obowiązki względem wiary i moralności,

III - Obowiązki względem Kościoła i hierarchii,

IV - Obecność wiernych w miejscach świętych,

$\mathrm{V}$ - Praktyki religijne.

Niektóre $\mathrm{z}$ artykułów znajdują swoje odpowiedniki w pierwszej redakcji. W artykule pierwszym odnajdujemy niezmiernie ciekawe określenie stanu świeckiego w Kościele, a w drugim wyrażone zostało prawo świeckich do uczestnictwa w dobrach duchowych i prawo domagania się środków koniecznych do zbawienia. W rozdziale 
pierwszym ukazano obowiązki wiernych względem wiary i moralności ${ }^{66}$. W siedmiu kolejnych artykułach ukazano obowiązki wiernych względem Kościoła i hierarchii ${ }^{67}$. W rozdziale czwartym o obecności wiernych na miejscach świętych biskupi zwracali uwagę na powinności uszanowania miejsc poświęconych Bogu, m.in. poprzez skromność ubierania się. Zgodnie z rozstrzygnięciem kolejnych artykułów prezbiterium przeznaczone było tylko dla duchowieństwa, a jedynie prezydent RP mial prawo do zajmowania w nim miejsca. Nakrycie głowy w kościołach mogli nosić tylko żołnierze towarzyszący sztandarowi. Zabroniono przemów publicznych w kościołach i na cmentarzach grzebalnych a także wszelkiego rodzaju salw. W ostatnim rozdziale traktującym o praktykach religijnych biskupi umieścili szereg zaleceń wzmacniających życie duchowe wiernych ${ }^{68}$. Ostatnie dwa artykuły traktują o konieczności

${ }^{66}$ Wymienione następujące szczególowe obowiązki: kształtowania swego życia według zasad nauki Chrystusa oraz poznanie odpowiedniego zasobu wiadomości z zakresu religii; rodzicielski obowiązek wychowywania swych dzieci własnym przykładem życia i dołożeniem troski, by dzieci dogłębnie poznawały katechizm; śmiałe wyznawanie wiary w życiu prywatnym, towarzyskim i publicznym; unikanie kontaktów z heretykami, sekciarzami oraz zakaz czytania ich pism, a także uczęszczania na ich nabożeństwa; zakaz przynależności katolików do organizacji i zrzeszeń wrogich religii i Kościołowi; zakaz wydawania książek, pism i ulotek o treści religijnej bez zgody ordynariusza miejsca (nihil obstat); powinność wiernych zabiegania, by życie rodzinne i społeczne opierały się na podstawach chrześcijańskich; dbałość o świętość i nierozerwalność życia małżeńskiego; piętnowanie odstępstwa od zasad wiary, cudzołóstwa, konkubinaty i rozwody; skromność i czystość obyczajów ogłoszono obowiązkiem kobiet; zakaz uczęszczania na przeciwne wierze, Kościołowi i moralności przedstawienia; zakaz bywania w domach rozrywki niemoralnej i gier hazardowych; zakaz brania udziału w nieskromnych tańcach; zakaz urządzania wspólnych dla kobiet i mężczyzn plaż.

${ }^{67}$ Obowiązki dotyczyły: współpracy z hierarchią, obrona praw i interesów Kościoła; poczucie solidarności, przywiązania w stosunku do Ojca św., biskupów i kapłanów; ofiarność i pomoc proboszczom dla dobra Kościoła i parafii; przynależność do stowarzyszeń religijnych; uczestnictwo w pracach Akcji Katolickiej; wspóldziałanie w dziełach miłosierdzia; obowiązek zachowania pośrednictwa proboszcza w zwracaniu się do władz kościelnych; zakaz pociągania przez osoby świeckie osób duchownych przed sądy świeckie; zakaz noszenia strojów duchownych przez osoby świeckie.

${ }^{68}$ Biskupi szczególny nacisk położyli na częste uczestnictwo wiernych we Mszy św. oraz przyjmowanie Komunii św. Obowiązkiem rodziców jest jak najszybsze zapewnienie dzieciom daru chrztu św. w ciągu 3-8 dni od czasu narodzin. Wrócono uwagę na powinność codziennej modlitwy, rozmyślania i rachunku sumienia, wspólnej modlitwy rodzinnej i posługiwanie się aprobowanymi przez władzę kościelną tekstami. Zalecono korzystanie z rekolekcji zamkniętych i uczestnictwo w nabożeństwach; biskupi zachęcali również do aktu intronizacji w każdej rodzinie obrazu Serca Jezusa, odprawiania nabożeństw w poszczególnych miesiącach oraz praktyki odmawiania modlitwy Anioł Pański. 
pokuty i podejmowania dobrowolnych praktyk pokutnych oraz pamięci o zmarłych, wyrażającej się przez nabożeństwa żałobne, modlitwy i utrzymywanie grobów.

Odpowiedzią na pismo sekretarza Komisji ogólnej, skierowanej do przewodniczącego Komisji De Sacramentis, był projekt statutów przesłany przez bpa Szelążka dnia 21 marca 1933 roku. Bp Przeździecki dnia 20 października 1933 roku rozesłał ten projekt członkom komisji rewizyjnej. Projekt zawierał 95 artykułów. Część De Sacramentis in genere obejmuje 7 artykulów, De Baptismo - 17, De Confirmatione - 6, De SS. Eucharistia - 23, De Poenitentia - 11, De Extrema Unctione - 4, De Ordine - 6, De Matrimonio - 13, De sacramentalibus -8 artykułów.

W części $O$ sakramentach $w$ ogólności odnaleźć można zalecenia skierowane do proboszczów, by często pouczali o sakramentach, ich naturze i konieczności oraz o warunkach godnego i owocnego ich przyjmowania. Wyrażono nakaz ścisłego przestrzegania ceremonii Rytuału rzymskiego przystosowanego do warunków polskich w sprawowaniu sakramentów i sakramentaliów. Do sprawowania sakramentów pasterze powinni być zawsze duchowo przygotowani, a jeśli wierni nie w porę proszą o ich spełnianie - należy im wyjaśnić odmowę lub opóźnienie w ich spelnieniu. Projekty szczegółowo omawiały sprawę przechowywania olejów świętych; powinny być przetrzymywane w czystych i przyzwoitych naczyniach w kościele. Nie powinny być przechowywane na plebani, chyba, że z konieczności i za pozwoleniem ordynariusza (zgodnie z kan. 735). W projekcie znalazło się dozwolenie by część oleju chorych przechowywać w domu w fioletowej bursie, w vasculum. Zabronione jest świeckim otwierać bądź przenosić naczynie z olejami święty$\mathrm{mi}^{69}$. Projekty przepisów synodalnych wskazywały na obowiązki proboszczów związane z dokumentacją zawartą w księgach metry$\mathrm{kalnych}^{70}$. W częśsi drugiej projektu umieszczono rozstrzygnięcia odnoszące się do Sakramentu chrztu; gwoli prawdy, większość sfor-

\footnotetext{
${ }^{69}$ AKS, jw. p. 5.

${ }^{70}$ Wśród obowiązków proboszcza wymienia się konieczność posiadania parafialnych ksiąg metrykalnych, obowiązek odnotowywania w ciągu 14 dni w księgach metrykalnych, gdzie został udzielony chrzest, informacji o udzieleniu bierzmowania, zawarciu związku małżeńskiego, przyjęciu subdiakonatu lub uroczystej profesji-AKS, jw., p. 6-7. Takie rozstrzygnięcia byly aplikacją norm kodeksowych - kan. 798, 1103 \& 2, 1988, $1011,5776 \$ 2$.
} 
mułowań projektu jest praktycznym przedstawieniem obowiązków kapłanów wynikających z kanonów kodeksowych ${ }^{71}$. W stosunku do rodziców wykazano ich obowiązek zatroszczenia się o to, by ich dzieci były ochrzczone w ciągu co najwyżej ośmiu dni od narodzin ${ }^{72}$. Aplikując rozstrzygnięcia kodeksowe (kan. 765 i 766), projekt synodalny wskazał, iż nie może być chrzestnym osoba należaca do sekty heretyckiej, bądź wydalona z kapłaństwa, rodzice lub małżonek chrzczonego dziecka. Nadto, chrzestny powinien mieć powyżej 14 roku życia, powinien być nie ekskomunikowany, ani nowo ochrzczony; nie powinien to być profes bez pozwolenia swego przełożonego ${ }^{73}$. Kolejne projektowane uchwały zawierały rozstrzygnięcia odnoszące się do świadków chrztu, imion dzieci, chrztu dorosłych $^{74}$. W przypadku dzieci rodziców nieznanych proboszcz miał

${ }^{71}$ Wskazano m.in., iż udzielanie chrztu zarezerwowane jest własnemu proboszczowi w swojej parafii, który nie może chrzcić obcych mieszkańców, ani podróżnych bez licencji ich własnego proboszcza, z wyjątkiem, gdy obcy mieszkaniec nie może tego uczynić bez wielkiej niedogodności - p. 8. W przypadku zagrożenia życia dziecka rodziców obrządku łacińskiego, może je ochrzcić kapłan innego obrządku, ale rodzice mają obowiązek zatroszczenia się o to, by ów kapłan przesłał świadectwo chrztu do właściwego proboszcza. W przypadku niechęci wydania takiego świadectwa proboszcz obrządku łacińskiego powinien spisać odpowiedni protokół w obecności rodziców dziecka i świadków ceremonii - p. 10. Obowiązkiem proboszcza jest sprawdzić to, co związane jest z ważnością i godziwością udzielanego sakramentu, a także intencję dokonującego ten sakrament oraz materię, formę $i, w$ trudnych przypadkach, sposób udzielania chrztu. Nie można po raz wtóry chrzcić nie sprawdzając ważności chrztu - p. 11-12. Odnośnie do dzieci znalezionych wskazano, że kartka, na której zapewniano by o chrzcie dziecka daje małą pewność moralną. Dlatego, poza przypadkiem starannie zbadanym, dzieci porzucone chrzci się warunkowo - p. 14. Przy chrzcie dzieci rodziców niewierzących, schizmatyków, heretyków lub chorych umysłowo należy stosować się do kanonów 750, 751, 754.

${ }^{72}$ AKS, jw., p. 16.

73 Jw., p. 17.

${ }^{74}$ Do chrztu należy wybrać po jednym ojcu chrzestnym i jednej matce; pozostali zaproszeni mogą być potraktowani jako świadkowie pomocniczy, i jako tacy wpisani do $\mathrm{ksiag}-\mathrm{p}$. 18. Dzieciom powinno się nadawać imiona świętych lub błogosławionych Kościoła, a w przypadku niemożliwości zmienienia pogańskiego imienia, należy dodawać imię chrześcijańskie (p. 19). Dzieciom nielegitymowanym należy nadawać imiona chroniące od niesławy (p. 20). Dorosłych proboszcz może chrzcić bez odnoszenia się do ordynariusza, zachowujace przepis kan. 752. Przy nawróceniu heretyka, który chce być przyjęty do Kościoła po ukończeniu 14 roku życia, należy zbadać ważność chrztu; jeśli chrzest był ważny, po wyrzeczeniu się herezji i wyznaniu wiary nie należy dokonywać powtórnej ceremonii chrztu. Przy wątpliwości ważności chrztu, po wyrzeczeniu się błędu, należy warunkowo ochrzcić proszącego według obrzędu dla dorosłych, albo na zasadzie dyspensy dla słusznej przyczyny, po sakramentalnym wyznaniu grzechów warunkowo rozgrzeszyć. Wobec dzieci poniżej 14 roku życia nie wymaga się wyrzeczenia herezji, ani absolucji z niej. Protokól chrztu lub nawrócenia, podpisany w księdze nawró- 
nadawać imię lub imiona oraz wpisać do księgi ochrzczonych po przyjęciu zawiadomienia w urzędzie stanu cywilnego; praktyka taka byla zgodna z państwowymi przepisami (Dz.U. RP 1927 nr 27, poz. 413 i nr 36, poz. 325) ${ }^{75}$.

Na wstępie kolejnej części, dotyczącej bierzmowania, biskupi zwracają uwage na obowiązek usilnego starania pasterzy o to, by wszyscy w stosownym czasie przystąpili do tego sakramentu. Dlatego też przypomniano dyspozycje kanonów 798 i 470 \& 2 odnoszące się do obowiązku wpisywania faktu bierzmowania do księgi chrztów ${ }^{76}$.

W części $O$ świętej Eucharystii biskupi zachęcali wiernych do uczestnictwa w codziennej Mszy św. wskazując najpierw, iż jest ona centrum kultu publicznego. W punkcie 34 umieszczona została dyspozycja by tam, gdzie jest wielu kapłanów nie powinni oni koncelebrować, lecz o różnym czasie sprawować Eucharystię. Rozstrzygnięciem, które jest wyjątkiem od przepisów powszechnych Kościo$\mathrm{la}^{77}$ jest pozwolenie by kapłani obrządku łacińskiego odprawiali Msze św. na portatylach, jak również by kapłani obrządków wschodnich przypisani do polskich diecezji odprawiali nabożeństwa w kościolach obrządku łacińskiego ${ }^{78}$. Powołując się na instrukcję Kongregacji ds. Sakramentów z dnia 26 marca 1929 roku, przypomniano, że materia Eucharystii powinna być pewna, czysta i ważna. Hostie powinny być wytwarzane w zakonach, a wino sprowadzane przez kupców katolickich, a nie żydowskich handlarzy ${ }^{79}$. Wśród wielu innych rozstrzygnięć dotyczących zagadnień związanych z Eucharystią, wskazano, że zazwyczaj do Komunii św. dopuszczane są dzieci w pierwszej lub drugiej klasie szkoly powszechnej ${ }^{80}$. Trzy ostatnie artykuły tej części traktowały o wystawieniu Najświętszego Sakramentu. Stwierdza się w nich, że nie dozwala się odprawiania mszy podczas wystawienia Najświętszego Sakramentu (p. 50), jedynym wyjątkiem są msze sprawowane w święto i przez

conych przez proboszcza, ochrzczonego i dwóch świadków, w jednym egzemplarzu należy przesłać do Kurii diecezjalnej (p. 21).

${ }^{75} \mathrm{Jw}$, , p. 22.

${ }^{76}$ AKS, jw., p. 26-30.

${ }^{77}$ Kan. $823 \$ 2$

${ }^{78}$ AKS, jw., p. 35-36.

${ }^{79}$ Jw., p. 39.

${ }^{80}$ Jw., p. 45. 
oktawę Bożego Ciała oraz podczas 40-godzinnego nabożeństwa (p. 51). Pozostałe, szczegółowe dyspozycje dotyczyły opieki duchowej nad chorymi (p. 48-49), stosownego ubioru podczas nabożeństw (p. 43) oraz zachęcania do częstego przyjmowania Komunii św.

Część $O$ sakramencie pokuty rozpoczyna się przypomnieniem proboszczom, wikariuszom i rektorom kościołów obowiązku codziennego spowiadania wiernych w godzinach rannych i popołudniowych ${ }^{81}$. Wśród wielu szczegółowych rozporządzeń dużo miejsca poświęcono konieczności wzajemnej pomocy duchownych, np. w spowiadaniu wiernych (p. 55-59). Wskazano również na sposób sprawdzenia zadośćuczynienia obowiązkowi rocznej spowiedzi poprzez składanie w zakrystii kartek po odbytej spowiedzi (p. 63).

Pierwszy artykuł części $O$ ostatnim namaszczeniu zawiera na początku zachętę skierowaną do proboszczów, by nie odkładać sprawowania tego sakramentu, lecz dokonywać go w stosownym czasie. Należy więc go udzielać w niebezpieczeństwie prawdopodobnej śmierci. W dalszych przepisach biskupi dają konkretne wskazówki; wierni nie powinni prosić o tę posługę kapłanów w niedziele i święta, ani przywozić chorych do kościoła, a dzieci namaszczane przed przyjęciem chrztu powinny spełniać warunek zdolności do jego przyjęcia $^{82}$.

Część $O$ święceniach rozpoczyna się przypomnieniem nakazów kanonów 998-1000, mówiących o okresie przed dopuszczeniem do wyższych święceń. Dyspozycje zawarte w projekcie wskazywały, iż obowiązkiem proboszcza jest przesłanie świadectwa braku przeszkód do święceń, troska o modlitwę wspólnoty w intencji kandydatów, a ogłoszenia powinny być dokonywane w dni świąteczne gromadzące większą liczbę wiernych ${ }^{83}$.

Część $O$ matżenstwie, tak jak i poprzednie, jest praktyczną aplikacją przepisów kodeksowych i, często, ich powtórzeniem. Biskupi zawarli w projekcie rozstrzygnięcie, iż proboszcz dopiero ma prawo asystować przy zawieraniu małżenstwa od dnia, przyjętego w dekrecie nominacji, wejścia w posiadanie parafii, natomiast wikariusz po-

${ }^{81}$ Jw., p. 53 \& 1 i 2 Biskupi mówią także o obowiązku stroju w czasie spowiadania (sutanna, komża, fioletowa stuła), wskazują tė̇, że spowiedź kobiet może odbywać się tylko w konfesjonale. Za brak przestrzegania tego ostatniego grozi kara $\mathrm{z}$ suspensą włącznie (p. 60).

${ }^{82}$ Jw., p. 64-69.

${ }^{83} \mathrm{Jw}$, p. 69-73. 
siada stałe pozwolenie asystowania przy zawieraniu malżeństwa od momentu rozpoczęcia obowiązków w parafii aż do czasu otrzymania dekretu przeniesienia ${ }^{84}$. Jedna $z$ dyspozycji zabrania ściągania opłat w związku z przesyłaniem wyciągów z ksiąg metrykalnych ${ }^{85}$. W projekcie biskupi zawarli zakaz zawierania malżeństw mieszanych z akatolikami, chyba że zostanie zawarte po otrzymaniu dyspensy od przeszkody różnej religii ${ }^{86}$. W końcowych projektowanych przepisach nakazano zachować zwyczaj spowiedzi i badania przedślubnego. Wskazano również, że należy nakłaniać wiernych, by uroczystości weselne nie odbywały się w wigilie świąt i w soboty.

Dziewiąta i ostatnia część tego projektu zawiera normy o sakramentaliach $^{87}$.

Komisja De locis et temporibus sacris et de cultu Divino przesłała swój projekt sekretarzowi synodu 9 lutego 1932 roku. Uczynił to biskup plocki - Łukomski ${ }^{88}$. Część o miejscach i czasach świętych składała się z trzech podrozdziałów: 1) De ecclesiis, altaribus eorumque ornamento, 2) De sepultura ecclesiastica, 3) De diebus festis łącznie 19 artykułów.

Część o kulcie Bożym zawierała 14 artykułów. W początkowych rozstrzygnięciach tej częśsi przejawia się głęboka troska autorów projektu skierowana ku temu, by ukrócić samowolę budowania, odnawiania i przyozdabiania kościolów. Dlatego na początku wszelkich przepisów tej części umieszczono nakaz zglaszania ordynariuszowi przewidywanych poczynań w zakresie spraw budowlanych i renowacyjnych - wraz z preliminarzem wydatków, by móc otrzymać zezwolenia na nie ${ }^{89}$. Szczegółowe nakazy dotyczyły konieczności używania konopeum przykrywającego artystycznie wykonane tabernakulum (p. 2), nakazano zdjąć, o ile nie zostały umoco-

${ }^{84}$ Jw., p. 74-75.

${ }^{85}$ Jw., p. 77.

${ }^{86}$ Jw., p. 82-83. Obrzęd taki musi być sprawowany wedtug ceremonii zawartych w Rytuale rzymskim, jednak bez sprawowania ofiary mszy św. $i$ uroczystego błogosławieństwa.

${ }^{87}$ Jw., p. 87-93. Mówi się w nich, że sakramentalia, jako szczególne środki pielęgnowania pobożności i życia duchowego wiernych, powinny być objaśniane, a świętowanie wielu zwyczajów ludowych powinno budzić ducha religijnego wiernych. Kapłani katoliccy powinni się powstrzymywać od święcenia różnych instytucji publicznych, jeśli byliby zaproszeni na nie kaplani akatoliccy.

${ }^{88}$ AKS, cz. 7, k. 5.

${ }^{89}$ Jw., k. 1, p. 1. 
wane, w obiektach kościelnych wszelkie rzeźby, malowidła i epigrafy poświęcone zmarłym (p. 3); wspomniano również o konieczności umieszczania naczyń $\mathrm{z}$ wodą święconą oraz tablic informacyjnych w pobliżu wejścia do kościoła (p. 4, 5). Służba kościelna (organiści, zakrystianie) powinni być zatrudniani na podstawie umowy, oplacani i zwalniani przez rektora kościola (p. 6). W podrozdziale o kościelnych cmentarzach zakazuje się grzebania zmarłych, którzy kazali spalić swoje ciało (p. 7). Wskazano na konieczność posiadania przez parafię kaplic cmentarnych lub repositoriów oraz na powinność uporządkowania cmentarzy włącznie z ponumerowaniem poszczególnych grobów (p. 9, 10 § 1-3). Wśród projektowanych przepisów dotyczących dni świątecznych, biskupi zwracają uwagę, że nie należy, zgodnie z przepisami powszechnymi, przywracać świąt contra legem. Wskazano jednocześnie święta uznane przez prawo świeckie, w których zachowuje się porządek tak, jak w święta $s u b$ praecepto $^{90}$. W punkcie 17 zawarto nakaz obchodzenia świąt wlasnych kościołów, odpustów, dedykacji i tytułów kościołów z ipso die na najbliższą niedzielę.

W części $O$ kulcie Bożym biskupi zwrócili szczególną uwagę na konieczność oddzielenia w kościele mężczyzn od kobiet i zachowania przez te ostatnie stosownego stroju (p. 20). Uwadze biskupów nie umknęły takie szczegóły, jak zdyscyplinowanie osób przebywających w prezbiterium; poza kapłanami mogą w nim przebywać urzędnicy państwowi ze względu na ich godność. Zakazano używania światła elektrycznego w świątyniach i nakazano przestrzegania przez duchowieństwo Rytuału zatwierdzonego przez Kongregację Swiętych Obrzędów oraz motu proprio papieża Piusa XI z 1927 ro$\mathrm{ku}^{91}$. Inne projektowane przepisy dotyczyly używania zatwierdzonego przez synod śpiewnika (p. 27-28) oraz zachowywania w obrzędach języka liturgicznego (p. 29).

Prace w kolejnej komisji De magisterio ecclesiastico rozpoczęto 20 stycznia 1932 roku, gdy bp Łukomski zwrócił się do bpa Przeździeckiego z prośbą o sprecyzowanie zgłoszonych przez niego tematów w zakresie nauczania w Kościele i w fakultetach teologicznych $^{92}$. 11 sierpnia bp Łukomski przesłał propozycje swojej

\footnotetext{
${ }^{90}$ Jw., p. 14-15.

${ }^{91}$ Jw., p. 21-24.

92 Jw., cz. 8, k. 1.
} 
komisji. Projekt nie zawiera materiału podzielonego na artykuły. Biskupi stwierdzają, że jasne i odpowiednie poznanie prawd wiary jest warunkiem indywidualnego i publicznego życia religijnego, moralnego porządku i społecznej pomyślności. Dlatego przede wszystkim rodzice są odpowiedzialni, za to by ich dzieci po dojściu do używania rozumu poznawały prawdy wiary i były dopuszczone do sakramentów pokuty i Eucharystii. Wiek rozpoznania rozumu (discretionem animi) w polskich warunkach klimatycznych obliczony zostal na 7-9 rok życia dziecka. Biskupi zwrócili uwagę na doniostość katechezy przygotowującej do pierwszej spowiedzi. Katecheza powinna trwać cały rok i obejmować nauczanie o wierze, o łasce, o sakramentach, o chrzcie, pokucie i Eucharystii. Ewentualne skrócenie rocznej katechezy należy uzupełnić w drugim roku nauczania. Po pierwszej spowiedzi dzieci są dopuszczane do prywatnej komunii św., a po drugim roku przygotowań do uroczystej komunii św. ${ }^{93}$. Część druga dokumentu, nosząca nazwę Wychowanie religijne $w$ szkole, odwołując się do kanonów 1372-1373 wskazuje na poważny obowiązek rodziców i kapłanów czuwania nad wychowaniem religijnym dzieci w szkolach publicznych. Nauczanie w nich religii powinno być powierzone odpowiednim kaplanom (zaopatrzonych w specjalna misję kanoniczną dla prefektów), których obowiązkiem jest odprawianie nabożeństw $z$ homilią $w$ dni świąteczne $\mathrm{i}$ niedziele dla swoich uczniów oraz troska o funkcjonowanie pobożnych stowarzyszeń uczniów w szkole ${ }^{94}$. W kolejnej części $O$ nauczaniu katechetycznym biskupi, powołując się na kanony 13291336 CJC, wskazują na obowiązek wprowadzenia katechezy dla dorosłych przed mszami lub nieszporami ${ }^{95}$. Materiał katechetyczny powinien być podzielony na trzy lata ${ }^{96}$. Część De sacris concionibus traktuje o głoszeniu słowa Bożego. Będąc najpoważniejszym obowiązkiem kaplańskim, jest regulowane kanonami kodeksowymi (kan. 1337-1348) oraz normami wydanymi przez

\footnotetext{
${ }^{93} \mathrm{Jw} .$, k. 5 , s. 1.

${ }^{94}$ Wszelkie sprawy związane z funkcjonowaniem prefektów rozstrzyga dekret Świętej Kongregacji Soborów z dnia 22 lutego 1927 roku.

${ }^{95}$ AKS, cz. 8, s. 2.

${ }^{96} \mathrm{~W}$ pierwszym roku powinna być przekazywana nauka o prawdach wiary, $\mathrm{w}$ drugim - o przepisach, o grzechach, o łasce, a w trzecim roku - o sakramentach, cnotach, modlitwie i o liturgii kościelnej.
} 
Świętą Kongregację Konsystorialną dnia 28 czerwca 1917 roku. Dobrze przygotowane kazania nie powinny przekraczać pól godziny czasu, zawierając treści ściśle teologiczne, ale niekoniecznie powinny unikać spraw świeckich, ekonomicznych i politycznych. Bez zgody ordynariusza miejsca kapłani i wierni świeccy nie powinni uczestniczyć w publicznych dyskusjach o prawdach wiary. W części dotyczącej misji świętych wskazuje się, że zgodnie $\mathrm{z}$ rozumieniem kan. 1349 CJC mają one miejsce raz na pięć lat w każdej parafii. Kolejny rozdział, zatytułowany $O$ zakazanych ksiązkach $i$ ich cenzurze $e^{97}$, wskazuje na obowiązek posiadania przez duchownego zgody ordynariusza miejsca na publikacje w gazetach i książkach. Zakazano wiernym świeckim przyjmowania czasopism $\mathrm{z}$ rąk heretyków, a takowe przekazane kapłanom powinny być spalone. Ostatnia część - O stowarzyszeniach katolickich - wskazuje na ich doniosłe znaczenie dla katolickiego wykształcenia młodzieży. Wszelkie stowarzyszenia powinny się skupiać w jednym działaniu w Akcji Katolickiej.

Komisja De beneficiis et bonis temporalibus, której pracom przewodniczył arcybiskup lwowski - Twardowski, rozpoczęła swoją pracę dnia 15 czerwca 1932 roku. W tym dniu arcbp Twardowski zwrócił się do bpa Przeździeckiego z prośbą o podanie nazwisk biskupów wchodzących w skład komisji. Wspomniał, że nie miał wiary „aby było rzeczą wskazaną, żeby przygotowywać synod plenarny, skoro w pojedynczych diecezjach jeszcze nie odbyto synodów diecezjalnych"øs. W odpowiedzi bp Przeździecki przesłał skład osobowy komisji oraz prosił o nadsyłanie do dnia 15 sierpnia materiałów przez nią opracowanych ${ }^{99}$.

Przebieg pracy przedstawiono w protokołach. Po raz pierwszy biskupi spotkali się w dniach 14 i 15 lutego 1933 roku we Lwowie. Jako temat zasadniczy obrano zagadnienia zawarte w V i VI księdze Kodeksu Prawa Kanonicznego (kanony 1409-1551). Obecni byli arcbp Twardowski, biskupi: Dembek, Adamski, Radoński, Laubitz oraz ks. Infułat Zajchowski - prepozyt kapituły lwowskiej. W toku dyskusji stwierdzono, że niektóre z kanonów domagają się gruntownego przystosowania do polskich warunków funkcjonowania

\footnotetext{
${ }^{97}$ Odnośne kanony: 1385-1392.

${ }^{98}$ AKS, jw., cz. 9, k. 1.

${ }^{99}$ Jw., cz. 9, k. 2.
} 
Kościoła ${ }^{100}$. Ostatecznie zdecydowano podzielić się pracą w opracowaniu poszczególnych tematów. I tak: bp Laubitz miał opracować kanony 1409-1447, 1472-1488, 1495-1543; arcbp Twardowski kan. 1489-1494, bp Adamski - 1448-1471, bp Radoński - 1544-1551. Na tym zakończyło się pierwsze posiedzenie tej komisji ${ }^{101}$.

Drugie posiedzenie komisji odbyło się w dniach 7 i 8 lutego 1934 roku w pałacu bpa St. Adamskiego w Katowicach. Zgodnie z wcześniejszym podziałem zadań wygłaszano referaty, wybie rając problematyczne w polskich warunkach zagadnienia kodeksowe. Biskup Laubitz, odwołując się do przepisu kanonu 1427 \& dotyczącego podziału uposażenia przy tworzeniu nowej parafii, stwierdza, ze tam, gdzie uposażenie jest contra honestam et congruam od Państwa należy żądać, aby z różnicy ryczałtów ustalonych w Konkordacie a nie wyplaconych przez Skarb, utworzyć fundusze wyrównaw$\mathrm{cze}^{102}$. Rozstrzygnięto zagadnienia szczegółowe dotyczące tworzenia beneficjów (kan. 1411), m.in. określenie tempus utile postanowiono pozostawić decyzji ordynariusza (zgodnie z kan. 458), podobnie jak dysponowanie dobrami beneficjalnymi (dotyczy kan. $1415)^{103}$. Bp Adamski przedstawił wnioski dotyczące zagadnień de iure patronatus (kan. 1448-1471). Stwierdziwszy, iż sprawę patrona-

${ }^{100}$ Wśród zagadnień domagających się rozważenia wyszczególniono pytanie czy beneficja mają być amovibilia, czy też inamovibilia (kan. 1441). Problem, który należało wyjaśnić, to kwestia kiedy ze względu na liczbę parafian należy dokonać podziału parafii (kan. $1427 \S 2$ ), nadto określenie pojęcia "sustentatio honesta et congrua" (kan. 1427 \& 4). Zwrócono uwagę na sprawę ablucji ciężarów patronackich (kan. 1470) i problem czy ziemia oddana Kościolowi powinna podlegać parcelacji. Wskazano na obowiązek tworzenia funduszy budowlanych, służących możliwościom pobierania pożyczek na remonty budynków kościelnych (kan. 1476 \& 1). Inne zagadnienia poruszone przez biskupów to konieczność uszczegółowienia określenia „minores reparationes”, do jakiej są zobowiązani beneficjanci źle administrujący swymi beneficjami (kan. 1477 §3). Co do kanonu 1479 dotyczacego ,anticipatae solutiones ultra semestre prohibentur" wskazano na przepisy Lutkoka, zatwierdzone przez synod łęczycki. Statut Lutkoka pochodzi z roku 1466. Postanawia on, że każdy beneficjat umierający lub odchodzący w pierwszych trzech miesiącach roku kalendarzowego zatrzymuje czwartą część rzeczywistej wartości dochodu, lecz zasiewy powinien zostawić w całości swemu następcy. Odchodzący w drugim ćwieréroczu zatrzymuje połowę dochodów; w III kwartale - trzy czwarte, a w IV kwartale całość dochodów. Wiele szczegółowych kwestii poruszonych przez biskupów nie sposób w niniejszym opracowaniu wykazać.

${ }^{101}$ Jw., k. 3.

${ }^{102}$ Jw., k. 4 i 5 - w aneksie protokołu znalazło się uzasadnienie prawne tego rozstrzygnięcia.

${ }^{103}$ Jw., k. 6-7. 
tów rozstrzygnął już Konkordat w art. 21, a skromne ich tradycje przetrwały jedynie w Małopolsce, na Śląsku Cieszyńskim i w byłym zaborze pruskim, należy odstąpić od formułowania materiału prawnego na synod (k. 8). Kolejne zagadnienia, związane $z$ kanonami 1472-1483, referowal bp Laubitz. Wiele zagadnień było powtórzeniem dyspozycji kodeksowych, m.in. odnośnie do obowiązku składania testamentów przez kapłanów (kan. 1473), co do ciężarów beneficjalnych (kan. 1475), prawa dziekanów do czuwania nad majątkami beneficjalnymi (kan. 1478). Projekt artykułów I-III zawierał dyspozycje o prawie powolywania dziekanów, oraz o ich prawach i obowiązkach ${ }^{104}$. W dalszej części swego referatu biskup Laubitz przedstawił opracowanie zasad przechodzenia beneficjów. Ostatnie zagadnienie dotyczyło przekazywania ruchomych dóbr kościelnych przez duchownych (o czym mowa w kan. 1533) za zgodą ordynariusza biedniejszym kościołom lub deponowania ich w muzeach diecezjalnych (k. 20). Kolejnym referentem byl bp Radoński, który przedstawił swoje wnioski dotyczące fundacji kościelnych (odnośnie do kan. 1544-1551). Mogą one powstawać na podstawie przepisów prawa kościelnego lub państwowego, ale istnieje jednocześnie wymóg zezwolenia ordynariusza, zawie rającego określenie sposobu zabezpieczenia majątku i cel użycia dochodów (k. 22). Arcbp Twardowski wskazując na referowane przez siebie kanony 1489-1494, traktujące o innych instytucjach kościelnych, stwierdził, że nie ma potrzeby wprowadzania zmian do ich funkcjonowania w Kościele polskim. W aneksie 15 biskup Laubitz zawarł instrukcję dotyczącą zarządu majątkiem kościelnym ${ }^{105}$.

\section{Dyskusja Konferencji Episkopatu nad wnioskami Komisji specjalnych}

Komisja ogólna na posiedzeniu w dniu 19 września 1933 roku w Częstochowie postanowila utworzyć dodatkowe Komisje kontroIne oraz zobowiązano komisje specjalne do ukończenia prac w terminie trzymiesięcznym od chwili dostarczenia materiałów przez se-

${ }^{104}$ Jw., k. 11

${ }^{105}$ Jw., k. 23 - instrukcja zawiera 154 artykuły posegregowane w sześciu częściach: 1) Zasady zarządu, 2) Rady parafialne, 3) Zarzad majątku kościoła parafialnego, 4) Zarząd majątku beneficjalnego, 5) Zarząd majątku zakładów kościelnych, 6) Fundusze fiducjarne. 
kretarza - bpa Przeździeckiego. Komisje miały być złożone $z$ trzech biskupów rozpatrujących projekty uchwał nadesłanych przez Komisje specjalne. Jednym $z$ tych trzech biskupów powinien być przewodniczący tej komisji, której narady bylyby rozpatrywane. Sekretarz Komisji ogólnej miał rozesłać czlonkom komisji kontrolnych protokoły narad komisji specjalnych, które to miały prawo zapraszać do pracy kogo uznają za stosowne ${ }^{106}$.

W okresie po konferencji w październiku bp Przeździecki rozsyłał projekty statutów zaproponowanych przez Komisje specjalne. W lutym 1934 roku przychodziły odpowiedzi Komisji kontrolnych. Szczególnie krytyczną i cenną przysłał arcbp Nowowiejski (datowana 17 lutego 1934 r.) ${ }^{107}$. Będąc przewodniczącym Komisji kontrolnej, nadesłał otrzymane od bpa Przeździeckiego projekty statutów De Sacramentis i De locis et temporis sacris et de cultu divino. Arcybiskup dołączył do wypowiedzi Komisji szczególną uwagę: „nasz Synod plenarny jest przedwczesny, że raczej wznowienie Soboru powszechnego byłoby konieczne"108. Przez poszczególne wnioski przewija się myśl, iż projekty statutów są zbytnio rozbudowane, ujmując za szeroki zakres spraw, zatracając tym samym, ich charakter prawny. List kard. Hlonda z 20 lutego 1934 roku komunikował przesunięcie kolejnego terminu synodu na dzień 23-25 maja 1935 roku. Tego samego dnia na Konferencji Plenarnej (20 lutego 1934 r.) oznaczono termin (do 20 marca 1934 roku) na przekazywanie wniosków do biura Episko-

${ }^{106}$ AKS, cz. 1, k. 7. W skład poszezególnych komisji kontrolnych wchodzili: 1. dla Norm generalnych: kard. Hlond, kard. Kakowski, arcbp Sapieha, 2. Dla duchowieństwa: arcbp Sapicha, bp Adamski, bp Jasiński, 3. dla zakonników: kard. Hlond, bp Gall, bp Radoński, 4. dla katolików świeckich: arcbp Jałbrzykowski, bp Lisowski, bp Dymek, 5. dla sakramentów: bp Nowowiejski, bp Szelążek, bp Barda, 6. dla miejsc świętych: bp Nowowiejski, bp Fulman, bp Dembek, 7. dla nauczania: bp Lukomski, bp Lakota, bp Tomczak, 8. dla beneficjów: bp Twardowski, bp Kubina, bp Latyszewski, 9. dla spraw sądowych: bp Tymieniecki (zm. 10.08.1934 r.), bp Szelążek, bp Rospond.

${ }^{107} \mathrm{Nr}$ 938/33.

${ }^{108}$ AKS, Projekty ustaw synodalnych 1934, k. 1. Arcbp Nowowiejski dołączył także inne swoje uwagi: „Synod plenarny winien obejmować najważniejsze normy konieczne i przydatne dla całej Polski, której Kodeks Prawa Kanonicznego nie mógł objąć. Nic może też synod plenarny zastępować teologii moralnej, pasterskiej, dzieł liturgicznych, tembardziej nie może zastąpić synodów diecezjalnych, które z natury rzeczy muszą uwzględniać właściwości miejscowe. Im więcej włoży się w synod przepisów, tembardziej zapewni się bezcelowość i bezskuteczność tego synodu. Dążyć by raczej należało do uproszczenia w korzystaniu z norm prawnych. Wątpię bardzo, czy przesłane referaty zadośćczynią podanym wyżej postulatom, wobec ich rozbieżności”. 
patu $^{109}$. Jednakże i ten termin stał się nieaktualny ze względu na chorobę kard. Hlonda.

Komisja ogólna dokonała posunięcia, które pozwoliło zrewidować uwagi wcześniejszych Komisji kontrolnych - utworzono Synodalną komisję nadzwyczajną. Jej przewodniczący kard. Hlond mial do pomocy biskupów Przeździeckiego, Szelążka, Bardę i bpa greckokatolickiego. Ustanowienie tej Komisji było realizacją postanowień Zjazdu Biskupów odbytego w dniach 20 i 21 lutego 1934 roku. Bp Przeździecki dnia 22 lutego wystosował pismo do arcbpa A. Szeptyckiego z zaproszeniem na posiedzenie Komisji w Poznaniu (18 kwietnia 1934 roku). Tenże listem z dnia 23 lutego podziękowal za zaproszenie i usprawiedliwił swoją niemożność przybycia stanem zdrowia. Prymas Polski przesłał na ręce bpa Przeździeckiego list zawiadamiając, iż posiedzenie Komisji nadzwyczajnej odbędzie się 20 kwietnia 1934 roku $^{110}$.

Na posiedzeniu tejże Komisji pojawili się kard. Hlond, bp Przeździecki, bp Barda; nie przybyli: bp Chomyszyn, bp Szelążek. Posiedzenie rozpoczęło się 20 kwietnia i trwało do 25 kwietnia. Mając na uwadze wcześniejsze wskazania biskupów postanowiono kierować się następującymi wytycznymi: nie powtarzać tego, co już było w Kodeksie; nie ścieśniać postanowień kodeksowych bez poważnej przyczyny; nie stwarzać prawa, które krępowałoby biskupów i stanowiło niepotrzebny ciężar dla duchowieństwa nie postanawiać czegoś, co nie będzie wykonane; wprowadzić pełną decentralizację - „mieć przed oczyma potrzeby całej Rzeczypospolitej, pozostawiając zarządzeniom właściwych Ordynariuszów specjalne potrzeby i przeszkody”. Innym postulatem było „mieć przed oczyma współdziałanie wszystkich obrządków na terenie Rzeczypospolitej i podkreślać przez to współdziałanie jedność Kościoła”, nie dotykać spraw specjalnych i liturgicznych obrządków wschodnich, a Kodeks uzupełniać tylko tam, gdzie on nie wyczerpuje istniejacych potrzeb ${ }^{111}$.

W dniu 20 kwietnia dyskutowano nad uchwalami Komisji Normae Generales i Komisji De clericis in genere et in specie. 21 kwietnia

\footnotetext{
${ }^{109} \mathrm{KE} 13, \mathrm{k} .4-5$.

${ }^{110}$ AKS, Projekt... 1934, k. 5-6.

${ }^{111}$ AKS, Protokół posiedzeń specjalnej komisji biskupów powołanej do opracowania uchwal różnych komisji synodu plenarnego, odbytych w pałacu arcybiskupim w Poznaniu, Projekty ustaw synodalnych 1934, k. 7-10.
} 
przyjęto wspomniane uchwały w nowej redakcji oraz dyskutowano nad uchwałami Komisji De religiosis i 24 artykułami Komisji De laicis. Następnego dnia - 22 kwietnia - toczyła się dyskusja nad pozostałymi uchwałami Komisji De laicis oraz uchwałami Komisji De Sacramentis - dzial Sacramentis in genere, de baptismo, de confirmatione, de Ss. Eucharistia. Kolejnego dnia obrad - 23 kwietnia - przyjęto uchwały Komisji De religiosis i De laicis w nowej redakcji oraz dyskutowano nad pozostałymi uchwałami z działu o sakramentach. Biskupi pracowali także nad uchwalami podjętymi przez Komisję De locis et temporibus sacris et de cultu divino oraz nad aneksami, umową z organistą i zakrystianem i nad statutem cmentarnym. 24 kwietnia przyjęto uchwały Komisji De Magisterio ecclesiastico i De beneficiis et bonis temporalibus. Ostatniego dnia obrad przyjęto nową redakcję uchwal, które były rozpatrywane 24 kwietnia oraz aneksy i instrukcje dla zarządu majątkiem kościelnym. Podjęto dyskusję nad uchwałami Komisji De iudiciis et causis beatificationis servorum Dei et canonizationis sanctorum. Przyjęto również nową ich redakcję. Obrady zakończono podjęciem następujących ustaleń:

- wybrać specjalną komisję, której zadaniem będzie poprawić Rytual z roku 1927 i wprowadzone poprawki przedstawić do zatwierdzenia Stolicy Apostolskiej,

- sekretarz Komisji mial przesłać nową redakcję uchwał do biskupów ordynariuszów, którzy mieli je przedyskutować z członkami kapituł, wybranymi kapłanami i prowincjałami zakonnymi. Uwagi miały wrócić do dnia 1 lipca 1934 roku do Biura Episkopatu.

Nową redakcję uchwał oraz protokól wyżej wspomnianego posiedzenia wydano drukiem i rozesłano po 10 egzemplarzy do poszczególnych ordynariuszów ${ }^{112}$.

Biskup Przeździecki 12 sierpnia wysłał do biskupów list, który ukazuje wkład włożony w dotychczasową pracę przygotowującą synod. Sekretarz tłumaczyl, iż ten etap pracy nie miał na celu układać uchwały w ostatecznej formie i stylizacji, lecz jako tezy robocze. List jest niejako odpowiedzią na zarzuty z jakimi spotkaly się projekty statutów we wcześniejszych wypowiedziach. Biskup zadal dwa pytania, które w istotny sposób miały wpłynąć na dalszy tok pracy Komisji:

${ }^{112} \mathrm{KE}, 13, \mathrm{k} .5$; są to uchwały, które były wynikiem dwuletniej pracy biskupów. Znajdujemy je na końcu pierwszego poszytu akt synodalnych w maszynopisie. Wydano je drukiem po posiedzeniu poznańskim (po 25 kwietnia 1934 r.). 
- czy w związku z różnicami zachodzącymi pomiędzy bylymi zaborami dążyć w uchwałach synodalnych do ustalenia ogólnych wytycznych, czy też łączyć rozstrzygnięcia,

- czy każdemu ordynariuszowi zostawić zupełnie wolną rękę w stosowaniu interpretacji prawa kanonicznego i konkordatowego, a co za tym idzie pozostawić swobodę w zarządzaniu diecezją.

Sekretarz Komisji ogólnej otrzymał 13 odpowiedzi, m.in. Kapituły Metropolitalnej warszawskiej (28.06.1934), biskupa płockiego (30.06.1934), Kurii Metropolitalnej krakowskiej (2.07.1934), Kurii Metropolitalnej lwowskiej (2.07.1934). W odpowiedzi na list biskupa Przeździeckiego z 12 sierpnia 1934 roku wnioski nadesłali: bp Szeptycki (29.08.1934 r.), bp Łukomski (18.08.1934 r.), bp polowy Gawlina (28.08.1934 r.), bp Dembek - sufragan łomżyński $(31.08 .1934)^{113}$. Wszystkie wyżej wspomniane listy były odpowiedzią na postawione wcześniej dwa pytania ${ }^{114}$.

Wnioski Kapituły warszawskiej podkreślały, iż projekt domaga się, ze względu na liczne braki, korekty. Należy odroczyć termin zwołania pierwszego synodu plenarnego dla uzgodnienia rozbieżności i różnic istniejących w prawodawstwie dzielnicowym poszczególnych polskich prowincji kościelnych (k. 54). Bp Nowowiejski, zasięgnąwszy opinii specjalistów, stwierdzał, ze w Symbolu Apostolskim należy mówić prawidłowo: „Pod Poncjuszem Piłatem”, a nie ,pod Ponckim Piłatem” - był to wniosek prof. Stefana Cybulskiego przedstawiony na posiedzeniu Polskiego Towarzystwa Filologicznego. Także wymóg języka oryginalnego domaga się stosowania w Zdrowaś Maryjo słów „Zdrowaś Maryja, łaski pelna” - uzasadnił to ks. St. Chodyński. Biskup plocki stwierdził także, że nie wolno, zgodnie z motu proprio Piusa X z dnia 22 października 1903 roku śpiewać pobożnych pieśni polskich wypierając jednocześnie pieśni mszalne. Zaproponował inne brzmienie $\mathrm{V}$ przykazania kościelnego: „Do utrzymania kościoła i sług jego wedle możności się przyczyniać”. W końcu zauważyl, że należy przepracować Instrukcję o zarządzie majątkiem kościelnym, gdyż nie można jej zastosować do warunków panujących w metropolii warszawskiej i wileńskiej (54 i 55). Metropolita krakowski, przekazując protokół z posiedzenia powołanej przez niego komisji, stwierdza, że wstrzymuje

${ }^{113}$ AKS. Projekty ustaw synodalnych 1934, k. 52-66.

${ }^{114}$ AKS, jw., k. 64. 
się od podania nowych, pozytywnych przepisów. Zajmuje jedynie krytyczne stanowisko wobec nadesłanego projektu (k. 57).

Swoje wnioski nadesłała Kuria Metropolitalna obrządku łacińskiego we Lwowie, podpisane przez bpa Bolestawa. Stwierdza się w nich, iż część uchwał zawiera ogólniki lub rzeczy oczywiste, lub dotyczy spraw dawno uregulowanych. Nadto materiał jest niedbale ułożony; w jednym kanonie znalazły się rozstrzygnięcia dotyczące testamentu kapłana i Konferencji Episkopatu; pogrzebu dotyczą różne uchwały w różnych częśsiach (IV. 3 i VI. 4). Także język wykazuje nieścisłe ujęcie prawne. Szczególną uwagę zwrócono na fakt, że ponad polowę uchwał zajmują sprawy materialne, za mało natomiast miejsca poświęcono sprawom kartotek parafialnych, stosunku do zagadnień politycznych, społecznych, kwestii bractw, Akcji Katolickiej, akcji dobroczynnej, organizacji młodzieżowych, sekciarstwa, teatru i kin, szkolnictwa, ochronek, alkoholizmu i życia małżeńskiego. Z zastrzeżeniami odniesiono się do Rytuału, w którym, jak się stwierdza, „język polski ma znacznie większe prawa w Niemczech niż w Polsce!". Postulowano także, iż nale ży „pozwolić np. na chrzest i pogrzeb po polsku tam, gdzie to dotąd jest w użyciu". Ostatni postulat dotyczył opuszczenia Instrukcji o zarządzie cmentarzy (k. 58).

Również bp Łukomski przedstawił swoje wnioski. Stwierdza w nich, że nakaz corocznych rekolekcji idzie dalej, aniżeli nakaz kodeksowy - wystarczy kaplanom nakazać odbywać takie rekolekcje co 2 lata. Także nakazy dotyczące zamieszkiwania kapłanów powinny uwzględniać możliwość zamieszkania u krewnych. Wskazał na nierealność zakazu zbierania ofiar podczas kolędy, gdyż jest to jedyna okazja otrzymania środków potrzebnych na remonty kościoła i składek na służbę kościelną. Wskazując na encyklikę pap. Benedykta XV Humani generis $\mathrm{z}$ dnia 15.06.1917 roku stwierdza, iż w projekcie za mało jest na temat wymogu zezwolenia ordynariusza na mowy pogrzebowe. Stwierdza również, że nie ma potrzeby zabiegania u Stolicy Apostolskiej o przeniesienie uroczystości i świąt zniesionych na niedzielę, a jedynie o uzyskanie odpustu w owe dni. W zakończeniu pisze, że nie ma potrzeby umieszczania aneksu $\mathrm{V}$ (dotyczącego cmentarzy), gdyż jest odpowiednia instrukcja kard. Pacelli'ego z dnia 4.05.1934 roku (k. 60 i 63).

W liście arcbpa lwowskiego - Andrzeja odnajdujemy jego jedyną wypowiedź: „muszę stanowczo oświadczyć się za pozostawie- 
niem ordynariuszowi jak najwięcej swobody w zarządzaniu diecezji” (k. 62).

Nadesłał swoje wnioski także biskup polowy Józef Gawlina. Wskazuje w nich, ze każdy żołnierz ma prawo do bezplatnych posług religijnych oraz, ze kapelan wojskowy ma prawo błogoslawienia małżeństw osób nie podlegających jego jurysdykcji, ale tylko na podstawie delegacji ordynariusza diecezji lub proboszcza miejsca. Nie powinno się używać pojęcia „duchowny wojskowy”, lecz „kapelan wojskowy, mający jurysdykcję proboszczowską", powolując się na art. 8 Statutu papieskiego, który skierowuje na art. VII Konkordatu. Zaproponowat uformowanie artykułu oznaczonego cyfrą 119 w nowym brzmieniu: „Aby błogosławieństwo małżonków, nawet w świątyni kapelana, było ważne, winien na terytorium parafii wojskowej posiadać prawa proboszcza wojskowego, bądź udzielać je osobie wojskowej lub członka jego rodziny. Gdy obie strony nie podlegają - musi posiadać delegację; jeśli jedna ze stron nie podlega jego jurysdykcji, należy uzyskać z parafii drugiej strony zaświadczenie o wygłoszonych zapowiedziach i nie zgłoszeniu przeszkód do zawarcia małżeństwa" (k. 65 i 66).

Swoje uwagi zgłosili również przedstawiciele Związku Polskich Zakładów Teologicznych. W swoim przedłożeniu stwierdzili, iż należy ustalić nazwę najnowszego obrządku - czy jest bizantyńsko-słowiański, czy wschodnio-słowiański lub też słowiański - bowiem nawet wydawnictwa watykańskie używają na jego określenie różnych terminów. Oprócz powyższego postulatu, dotyczącego statutu 7, (uformowanego przez środowisko Uniwersytetu Krakowskiego), przedstawiono pytanie przedstawicieli Uniwersytetu Wileńskiego dlaczego kongregacje dekanalne mają odbywać się tylko raz do roku (odnośnie do statutu 12). Przestrzeżono przed zbyt surowym przepisem o noszeniu sutanny, który może spowodować przebieranie się kapłanów w strój całkiem świecki. Co do statutu 16 profesorowie Uniwersytetu Krakowskiego stwierdzili, że nie ma wystarczającej racji, by synod plenarny mial zmieniać zwyczaje pewnych diecezji i okolic w tym zakresie. Do statutu 78 należy dodać konieczność wprowadzenia jednakowej formuły zapisywania wszelkiego rodzaju metryk. Zaproponowano skreślenie statutu 88. Profesorowie postawili zarzut nowym sformułowaniom synodalnym, że mszy św. nie można odprawiać na antymensach Greków, ponieważ zabrania tego kan. 823. Przedstawiciel Uniwersytetu Wileńskiego za- 
proponowal dodanie w statucie $69 \mathrm{nr} 4$ po wyrazach „poczętego życia” sformułowanie „zwalczać sztuczne poronienia”. Zwrócono uwagę, że należy w części De laicis sformułować rozdział De servitoribus Ecclesiarum (k. 52).

Dnia 31 sierpnia 1934 roku nadeszły uwagi sufragana łomżyńskiego - bpa B. Dembka, który stwierdzał, iż należy „usunąć różnice w sprawach kościelnych, dotąd istniejące w dawnych trzech zaborach” oraz domaga się „bezwzględnego ujednostajnienia interpretacji Prawa Kanonicznego i Konkordatu" (k. 67).

\section{Projekty uchwal}

Zredagowany tekst projektu ustaw synodalnych został przedstawiony biskupom na Konferencji Episkopatu w Częstochowie 3 września 1934 roku. Na wniosek kard. Hlonda prolongowano termin nadsyłania poprawek do projektu statutów synodalnych do 31 sierpnia 1934 roku. Po tym terminie sekretarz Komisji ogólnej miał przekazać projekt do zredagowania prawnikom, teologom i filologom. Prace te miano zakończyć do 1 kwietnia 1935 roku, ponieważ 2 kwietnia miała się zebrać Komisja ogólna by przyjąć końcowy tekst. Gwoli lepszego dopracowania tekstu ustaw prymas Hlond zaproponował przesłanie ich w prywatnej formie do Świętej Kongregacji Soboru ku przeanalizowaniu całego zebranego materiału. Termin odbycia synodu ustalono na sierpień 1935 roku. W uzupełnieniu bp Przeździecki zaproponował poszerzenie gremium konsultorów o kapituły, zakony, profesorów KUL-u i przedstawicieli fakultetów teologicznych ${ }^{115}$. Po raz kolejny uzgodniono treść poszczególnych artykułów, stylistyczne ujęcia pozostawiając komisji powołanej przez bpa Przeździeckiego. Skreślono aneksy do projektów statutów. Przedstawione wcześniej, a nadesłane przez bpa Nowowiejskiego projekty tekstów lekcji i ewangelii oraz modlitw liturgicznych mial przejrzeć do 15 marca 1935 roku kard. Kakowski. Teksty pieśni kościelnych miał przejrzeć kard. Hlond. Ich wnioski miały być przedstawione 2 kwietnia, również uwagi co do tłumaczeń mialy być przesłane do 15 marca 1935 roku do Biura Episkopatu $^{116}$.

${ }^{115}$ KE 13, Konferencja Komisji Ogólnej Synodalnej Częstochowa 3.09.1934; AKS, jw., k. 73 .

${ }^{116}$ AKS, jw. k. 69-70. 
Kard. Marmaggi przesłał do bpa Przeździeckiego dnia 18 października 1934 roku list, w którym Nuncjusz zapytywał czy sprawy obrządku wschodniego są uwzględnione w projektach statutów: „czy poruszono problem spodziewanego powrotu i czy zostały podjęte odpowiednie środki jego osiągnięcia. Ponieważ problem tego rodzaju nie był przewidywany, czy wydaje się wskazane go potraktować i w jaki sposób" "17. Wyczerpującą odpowiedź na pytania zawarte w liście kard. Marmaggi'ego przesłał bp Przeździecki 27 października 1934 roku $^{118}$. Wyliczy1, które statuty odnoszą się do obrządków wschodnich, wskazując na małe zaangażowanie się biskupów wschodnich w prace synodalne ${ }^{119}$.

W dalszym ciągu nadchodzity oceny i wnioski dotyczące drugiej redakcji projektu statutów synodalnych. Były to odpowiedzi na pismo bpa Przeździeckiego z dnia 15 września 1934 roku (nr 579). Uwagi nadestali: arcbp Teodorowicz (bez datowania) ${ }^{120}$, bp sando-

${ }^{117}$ Jw., k. 78. List z Nuncjatury Apostolskiej nr 12901, Warszawa 18.10.1934 r. Zawiera pytania: „I. An in propositis schematibus proximae Synodi Plenariae Poloniae Restitutae prae oculis habeatur etiam argumentum auspicati reditus „ortodoxorum" ad unitatem Ecclesiae Catholicae, necnon apta innuantur media ad unionem ipsam promovendam, II. Quatenus quaestio huiusmodi unionistica nondum praevisa sit, an opportunum censeatur ut tractetur et quomodo". List przybył do Kurii Siedleckiej 23.10.1934 r. (nr 5702).

${ }^{118}$ Jw., k. 79. List oznaczony liczbą dzienną 622. Po wymienieniu statutów bp Przeździccki przekazuje: „Declarandum est: responso accepto ab Excellentissimo Domino Archiepiscopo Metropolita Andrea Szeptycki: 1) proposita statutorum futurae Synodi omnibus Ordinarius ritus graeco-catholici mittuntur, sed adnotationes ad statuta ab iis nondum sunt accepate, 2) Ordinarii ritus graeco-catholici eorumque Auxiliares ad partes in Commisionibus synodalibus habendas sunt invitati, sed usque adhuc partes non habuentur. Audivi quendam Ordinarium ritus graeco-catholici loquentem, se nasciro, utrum partes in Synodo celebranda habendas sint, nec ne, nam Metropolita Szeptycki ipsis insciis litteris invitantibus rescripsit. Censeo laborem unionisticum sine participatione in eo omnium rituum - non modo apud nos, sed in toto orbe - non esse ultra progressurum, sed e contra recessurum, communis vero labor non modo apud nos, sed in toto orbe multos operarios in campo unionistico conciliabit".

${ }^{119}$ Statuty $7,11,12,32,35,36,76,80,91$ odnosza się do pytania pierwszego. Odnośnie pytania drugiego bp Przeździecki podał statuty 69, 144, 145, 151.

${ }^{120}$ AKS, t. 2, k. 80; także: Projekty ustaw synodalnych 1935, k. 11 - Pierwsza ocena, autorstwa arcbpa Teodorowicza, rozpoczyna się pochwalą, iż usunięto przewagę elementu materialnego nad duchowym w trésciach statutów. Jednocześnie arcybiskup stwierdził, że w częśsi o duchowieństwie został wprowadzony kierunek skrajnie ascetyczny, starający się odseparować kler od społeczeństwa świeckiego i nakładający takie ciężary, że albo pozostaną martwym przepisem, albo wzbudzi niepotrzebne rozgoryczenie wśród duchownych. Postawiono zarzut, iż nie brano pod uwagę wniosków Komisji de cleribus w ustalaniu treści statutów. Po tych generalnych uwagach przedstawione zostały szczegółowe. Dział I ar- 


\section{mierski (29 listopada) ${ }^{121}$, Kuria Metropolitalna w Krakowie (1}

cybiskup uznał za dobry, natomiast w dziale II dostrzeżono kwestie problematyczne: art. 16 i 17 uznane zostały za wadliwe. Na różnych terenach Rzeczpospolitej stosowano inne stroje, aniżeli sutanny, stąd propozycja, aby ordynariusze mogli przepisywać bardziej rygorystyczne normy odnośnie do stroju duchownych. Odnośnie do art. 18 i 19 stwierdzono, iz są niepraktyczne, a niekiedy wręcz niewykonalne; przymus mieszkania w hotelach lub domach wybranych przez władzę duchowną pod karą niedopuszczenia do oltarza wygląda na próbę skoszarowania kapłanów. Także art. 24 spotkał się z zarzutem. Odnoszący się do zakazu uczęszczania kapłanów do kin i teatrów, określony został jako „fatalny”. Autor z sarkazmem mówi, że należałoby zabronić wszystkim wiernym chodzenia do kin. Na obronę swego stanowiska wskazal, iź prefekt musi niekiedy iść wspólnie z młodzieżą do kina lub też na wycieczkę. Arcybiskup nie rozumie dlaczego artykuł ten został wzmocniony sankcja kary suspensy; jest to niepedagogiczne. Należy mieć więcej zaufania do kleru, wzorem tej postawy jest art. 138 i 140. Natomiast wielkim brakiem, według arcbpa Teodorowicza, jest brak umieszczenia uwag o dalszym kształceniu kleru, o czym mówi kan. 129 CIC oraz 48 projektu komisji biskupiej. Uważał również potrzebę postanowień o braniu udziału w życiu politycznym i społecznym. W dziale III arcybiskup zwraca uwagę, że brakuje umieszczenia między statutami 40 i 41 choćby kilku postanowień o kapitułach, dziekanach, archiwum i muzeum diecezjalnym. Odnośnie do rozstrzygnięć dotyczących kolędy (statut 44), Autor stwierdza, że nie powinno się wykluczać dobrowolnych ofiar. Co do statutu 53 arcbp Teodorowicz domaga się postanowień o subsidium charitativum, o domach emerytów i odpoczynkowych (Księzówka, Hel) oraz o sanatoriach (Krynica, Szczawnica, Truskawiec) dla księży, o czym było w projekcie Komisji (statut 18, 19, 20), a zabrakło w drugiej redakcji: „Niech synod okaże pewne staranie także o dobro kleru, a nie tylko obarcza go zakazami i karami” (str. 4). Arcybiskup nie zgadza się ze sformułowaniem tytułu V - „Laicy”. Należy używać pojęć „swicccy” lub „wierni”. Wskazane przez biskupów obowiązki wiernych, zdaniem arcybiskupa, są zbyt ciężkim zadaniem (m.in. codzienne rozmyślanie). Statuty 84, 97, 104, 107 uznane zostaly przez Autora za złe stylistycznie i domagające się przeróbek. W dziale VII zauważa konieczność dodania rozstrzygnięć o mieszkaniach wikariuszy i załatwienia nieuregulowanej sprawy zabezpieczenia służby kościelnej na starość lub wypadek choroby. Ewentualnym rozwiązaniem tej sytuacji byłoby wydzielanie działek ziemi z majątku beneficjalnego. W statucie $123 \mathrm{z}$ działu VII zwraca uwagę, iż należy poprawié i starannie wydać Rytuał. Odnośnie do statutu 126 Autor zwraca uwagę, że niesłusznie potępia się regionalizm w śpiewaniu. Zarzutem w stosunku do statutu 131 jest niewykonalność w państwie o szkołach koedukacyjnych i międzywyznaniowych tworzenia szkól jednowyznaniowych oraz nakaz rozdzielenia dziewcząt i chlopców. Zabrakło, zdaniem arcybiskupa, konkretnych postanowień odnośnie do seminariów oraz fakultetów teologicznych na państwowych uniwersytetach.

${ }^{121}$ AKS, t. 2, k. 81-82, nr 5637 - Kolejny list z uwagami przysłał biskup sandomierski (z dnia 29 listopada 1934 r.). W dokumentacji brak podpisu, ale należy przypuszczać, iż uwagi wywodzą się od ordynariusza Diecezji sandomierskiej, którym w tym czasie był bp Lorek. W części wstępnej listu, liczącego 4 strony, odnajdujemy uwagi wstępne; wśród nich najważniejsza to ta, iż w statutach odnajdujemy niepotrzebne powtórzenia kanonów CIC, np. statut 8 koreluje z kan. $125,140 \mathrm{z}$ kan. 1345 . Kolejny zarzut to zbyt ogólne ujęcie zagadnień karności kleru, obowiązków duszpasterskich, praw beneficjalnych oraz administrowania majątkiem kościelnym. Biskup zaproponował uwydatnienie autorytetu Papieża i Stolicy Apostolskiej; zauważa również, że należy wyjaśnić obowiązki biskupów sufraganów i ich stosunku do biskupów ordynariuszów. Biskupiej uwadze nie uszła sprawa niehabitowych i ukrytych zakonów. W dalszej części wypowie- 


\section{grudnia 1934) ${ }^{122}$, bp piński (5 grudnia 1934) ${ }^{123}$, bp łucki (5 grudnia}

dzi domaga się szerszego omówienia sakramentu małżeństwa i prawnego określenia zakresu obowiązków księży prefektów. Także niejednolicie traktowana sprawa opłat kancelaryjnych powinna być uregulowana. Dalsza, szczegółowa część uwag (str. 3-4) odnosi się do niektórych wybranych zagadnień. Odnośnie do kongregacji dekanalnych (statut 9) stwierdza, ze wystarczą tylko dwie, a nie proponowane cztery. Jako „zbyt mocno ujęte" określono zakaz obecności księdza w teatrach i kinach. Co do statutu 25 zapytuje, czy można żyć towarzysko z niepraktykującymi i notorycznie obojętnymi katolikami. Biskup sandomierski domaga się również wyjaśnienia jakiej karze suspensy podlega kapłan naruszający nakaz noszenia stroju duchownego (statut 29). Odnośnie do zbierania ofiar podczas kolędy domaga się użycia mocniejszego postanowienia zabraniającego (statut 44). Użyta w projekcie statutu 84 sankcja „pod grzechem ciężkim” wzmacniająca obowiązek rodzicielski wysyłania swych dzieci na katechizację, zgodnie $\mathrm{z}$ opinią biskupa, należy opuścić. Statut 111, dotyczący utrzymania służby kościelnej z funduszu kościelnego, wzbudził wielką wątpliwość. Takie rozwiązanie jest niebezpieczne, a na terenie byłego Królestwa wręcz nieprawdziwe. W myśl rozporządzeń kodeksowych (kan. 1182) rządca kościoła jest jednocześnie administratorem funduszu, ponosząc cięzary stąd wynikające. Biskupowi, prawdopodobnie, chodzi o zapewnienie nienaruszalności majątku funduszu. Służba kościelna powinna mieć utrzymanie od parafian za każdorazową posługę. Za nierozsądny uważa nakaz statutu 131 domagającego się porzucenia koedukacji; zapytuje: „czy dzieci mają przerwać naukę w całym państwie?”. Odwołujac się do statutu 140, Autor zauważa konieczność określenia ilości wiernych, potrzebną do obowiązku głoszenia nauki w czasie trwania mszy św. Biskup Lorek odnośnie do spożytkowania dóbr beneficjalnych, proponuje powrót do sformulowań kan. 1473, który lepiej precyzuje ten zakres spraw, aniżeli statut 156.

${ }^{122}$ AKS, t. 2, k. 83-84, nr 68 - Wnioski nadesłane przez Kapitułę Metropolitalną krakowską (z dnia 1 grudnia 1934 r.) zostały podpisane przez ks. Marcelego Ślepickiego dziekana tejże Kapituly. Odnośnie do statutu 9 wysunięto zastrzeżenie, iż w kongregacjach dekanalnych nie powinni brać udziału katecheci, jedynie w tej, która rozpoczyna rok szkolny. Nie ma potrzeby zawiadamiania o nich kurii diecezjalnych (statut 11). Jako „pożądany” został określony udział różnych obrządków w wyżej wymienionych kongregacjach (statut 12), jednakże z zastrzeżeniem unikania dyskusji politycznych. Odnośnie do statutu 14 zaproponowano, by przy egzaminach 3-letnich i na beneficja wymagać od kandydatów znajomości praw państwowych, dotyczących Kościoła. Stwierdzono, iż nakaz noszenia sutanny, wyrażony w statucie 16, zacieśnia nakaz kan. 136§1. Wyrażono wątpliwość co do przyjęcia się tego nakazu w diecezji śląskiej, gnieźnieńsko-poznańskiej, na Pomorzu i w Małopolsce. Wysunięto propozycję skreślenia w statucie 19 słów: „lub nie u krewnych I stopnia”. W statucie 22, dotyczacym zamieszkiwania na stałe Kapituła zaproponowała użyć zamiast słowa „przyjmować” - słowa „wynajmować”. Statut 24, zabraniający kapłanom wspólnej jazdy z niewiastami, domaga się albo skreślenia, albo wystylizowania zwrotu, które uwzględnia wypadki konieczne. Ściślejszego określenia domaga się statut 28 punkt c, gdzie dopowiedzeniem powinno być, iż zabrania się prowadzić handel osobiście lub na własny rachunek. Należy w statucie 29 opuścić drugi wiersz, który jest powtórzeniem i połączeniem kanonów 1516 i 1550 . Sformułowanie projektu statutu 31, nakazujące składanie testamentów w kurii, nie jest dobre. Testament kapłani powinni składać u dziekana lub u innych osób za jego wiedzą w formie ważnej pod względem prawa państwowego. Sposób spełniania kolędy powinni określać ordynariusze oddzielnymi przepisami (odnośnie do statutu 44). W statucie 51 znalazło się niejasne sformułowanic „skrypty dłużne”, które zdaniem autorów można zastąpić terminem „kwity”. W osobny 


\section{$1934)^{124}$, rektor WSD w Janowie Podlaskim (10 grudnia 1934) ${ }^{125}$,}

przepis zaproponowano ująć rozstrzygnięcia dotyczące taks za dyspensy i opłaty sądowe (mówi o tym kanon 1556 i 1909), lecz nie podciągać je pod iura stolae, jak to miało miejsce w projekcie. Postawiono zarzut, iz w statutach 58 i 59 brak jest przepisów, by nabożeństwa w kościołach zakonnych nie kolidowały z nabożeństwami w kościołach parafialnych, by zakony prowadziły osobną książkę chorych oraz o procesjach zakonnych poza murami klasztoru. Kapituła zaproponowała dodać zobowiązanie proboszczów do przesyłania raz do roku w określonym terminie autoryzowanego odpisu wszystkich aktów metrykalnych. W statucie 84 zastąpić należałoby zwrot „odłożywszy na bok” słowem „pomijając", podobnic termin „raport” terminem „sprawozdanie” lub „relacja”. Wnioskodawcy zwracają uwagę, iż jest wyraźny brak przepisów o protokołach przedślubnych pisanych, o nauce przedślubnej nowożeńców, o domaganiu się spowiedzi w okresie głoszenia zapowiedzi, rozstrzygnięć o obrzędach przy małzeństwach mieszanych. Ostatni postulat mówi o konieczności uwypuklenia roli katechizacji ludzi starszych.

${ }^{123}$ AKS, t. 2, k. 85, nr 5202 - Kolejny wniosek, biskupa pińskiego (z dnia 5 grudnia 1934 r.), dotyczy statutu 149, w którym wyrażono obowiązek młodych kapłanów, by przez pierwsze pięć lat pracy kapłańskiej spisywali swe nauki i przechowywali je. Biskup Bukraba, bo prawdopodobnic on ten wniosek wystosowat (nie ma bowiem podpisu), stwierdza, że takie zobowiązanie jest niepedagogiczne i obniża powagę prawa. Zamiast zobowiązania należy zalecić takie praktyki.

${ }_{124}$ AKS, t. 2, k. 86-87, nr 5197 - Wniosek biskupa Szelążka (z dnia 5 grudnia 1934 r.), biskupa łuckiego, rozpoczyna się wstępną uwaga, że należy zrezygnować z dyspozycji istniejących już w Kodeksie Prawa Kanonicznego, m.in. statut 5, 15 (korelatywny do kanonu 126), 22 (kan. 133), 140 (kan. 1345). Nadto należy zmienić statut 7, by się nie okazalo, że wierni innych obrządków nie podlegają statutom. Zaproponował wyrazić tę sytuację sformułowaniem: „Statuty synodu plenarnego obowiązują duchowieństwo i wiernych wszystkich obrządków, z zastrzeżeniem specjalnych praw tych obrządków”. Odnośnie kongregacji, o których mowa w statucie 12, wysuwa propozycję dodania słów „odbywać się kongregacje” słowa „wspólne”. Statut 32, mówiący o relacjach pomiędzy proboszczem a wikariuszem, który jest identyczny ze statutem 47, należy opuścić. Niejasność sformułowań statutu 77 powoduje konieczność takiego przeredagowania, które pozwoli odczytać jego sens. Jako niewykonalny ocenia statut 131, mówiący nauczaniu dzieci w szkołach niekoedukacyjnych; stąd propozycja opuszczenia go.

${ }^{125}$ AKS, t. 2, k. 88-90 - Z Janowa Podlaskiego nadeszły wnioski księdza A. Lipińskiego - rektora WSD w Janowie (z dnia 10 grudnia 1934 r.). Jego propozycja co do statutu 7 poleca zmianę zwrotu „z zastrzeżeniem” na „Z uwzględnieniem” - chodzi o zachowanie praw, innych od rzymskiego obrządków. Jako niejasny został określony statut 12, mówiący o kongregacjach dekanalnych, ze względu na przenikanie się terenów o rozmaitych obrzadkach. Autor zadaje pytanie czy kapłani wszystkich obrządków mają brać udział w tych kongregacjach. Jeśli chodzi o strój duchowny (statut 16) ks. Lipiński stwierdza, iż niejasne i niezdecydowane jest sformułowanie: „wystrzegać się przebierania”, natomiast w statucie 19 opuścić należy: „kapłan mieszkający bez zgody”. W statucie 22 umieścić należy słowa: „na dłuższe zamieszkanie”, zamiast słów „na mieszkanie”, natomiast w statucie 27 należy opuścić słowa: „przyjęte zaś”. W statucie 32, mówiącym o budowaniu relacji pomiędzy proboszczem a wikariuszem, proponuje użycie słowa „życzliwe” zamiast słowa: „serdeczne”. Wnioskuje także by w statucie 45 umieścić obowiązek odbywania konferencji przed Wielkim Postem, a statucie 47 więcej zachęcić kapłanów do odmawiania brewiarza. Tak jak w poprzednich wypowiedziach, tak i w tej pojawia się zarzut w stosunku do statutu 77 , iż jest niejasno sformułowany. 


\section{Wydział Teologiczny UJ (bez datowania) ${ }^{126}$, bp Eukomski (10 grud-}

W statucie 84, w którym mowa o wieku dopuszczenia do Komunii św., Autor proponuje opuścić słowa: „wiek odpowiadający drugiemu oddziałowi szkoły powszechnej”, natomiast w statucie 112 dodać słowa: „pracujący przy kościele powinni odznaczać się religijnością, czystością obyczajów”. Należy na nowo zredagować statut 137 , natomiast statut 151 rozbic na dwa statuty: w sprawie teologii Wschodu i w sprawie walki z bezbożnictwem. Końcowa ogólna uwaga dotyezy konieczności wydania wytycznych co do ujednostajnienia programów nauczania w seminariach i reguł seminaryjnych.

${ }^{126}$ AKS, t. 2, k. 91 - Także Wydział Teologiczny Uniwersytetu Jagiellońskiego przesłal, liczący 15 stron, elaborat. $\mathrm{Na}$ pierwszych 6 stronach odnaleźć można uwagi ogólne. Wskazano na konieczność uwypuklenia zgodności współdziałania społeczności kościelnej i państwa na podstawie encykliki Leona XIII Immortale Dei ( $\mathrm{z}$ dnia 1. 11. 1885 r.), Libertas, praestantissimum (z dnia 20.06. 1888 r.), Konkordatu i listu Prymasa o stosunku Kościoła do państwa i ich współdziałania. Projekt statutów został określony jako „blady, bezkrwisty, małostkowy", w którym ton policyjny względem kapłanów obarczonych „onus diei et aestus" wypływa na pierwszy plan. Ważniejsze kwestie zostały pominięte lub słabo potraktowane, m.in. sprawa kapitul, wydziałów teologicznych na uniwersytetach państwowych, Katolickiego Uniwersytetu Lubelskiego oraz parafii. Nie stworzono zasad rozdzielania prebend, nie poruszono sprawy funduszu dla delegatów i wizytatorów biskupich, które by regulowały koszta podróży i utrzymania. Należy ujednostajnić warunki udzielania misji kanonicznych dla kapłanów powołanych przez wydziały teologiczne do wykładów. W dalszej części wypowiedzi poruszono kwestię stworzenia funduszu wydawniczego i zasiłkowego dla dzieł i rozpraw z zakresu wszystkich gałęzi nauk teologicznych. Kolejnymi postulatami było stworzenie zespołu duchownych w każdej diecezji, którzy poświęcali by się wyłącznie głoszeniu Słowa Bożego, reorganizacja kurii i sądów biskupich, uregulowanie spraw probostw $\mathrm{i}$ ich prawnego statusu. Ostatni postulat podyktowany by występującymi różnicami w poszczególnych dzielnicach zaborczych; w jednych proboszczowie byli czasowymi administratorami, w innych parochi inamovibiles. Ujednostajnienia domaga się również kwestia pensji wikariuszowskich - statut $52 \mathrm{w}$ tym zakresie jest tylko namiastką. Wskazano na statuty 32 i 47 oraz 92 i 8 jako równobrzmiące, pokrywające się. W dalszej częśsi znajdują się wnioski poszczególnych statutów. Autorzy domagają się by w statucie 4 wspomnieć o zwyczajach 100-letnich, a statut 5, pokrywający się ze statutami 6 i 7, jest zbyteczny. Odnośnie do statutu 7 należy ustalić nazwę najnowszego obrządku. Dalszy postulat dotyczył dyspozycji statutu 16 odnoszącego się do noszenia sutanny; przepis prawny powinien uwzględniać przepisy diecezjalne i moźliwość innego stroju duchownego, zgodnie $\mathrm{z}$ rozporzadzeniem kanonu $136 \$ 1 \mathrm{CIC}$. Istnieje natomiast obowiązek noszenia sutanny podczas odprawiania mszy św., o którym mówi kan. $811 \S 1$. Odnośnie zamieszkiwania kaplanów (statut 19) rozstrzygnięcia projektu idą, zdaniem Autorów, zbyt daleko w stosunku do przepisów kodeksowych (dla porównania podano kan. 133, 804\$1-3). Odnośnie do uczęszczania kaplanów do kin (statut 24) uznano to rozstrzygnięcie za zbyt drobnostkowe i nieszczęśliwie zredagowane. Do statutu 25 dodać należy, iż nielegalne małżeństwa to nie tylko nieprawe związki, lecz również związki cywilne. Zakaz nabywania przez kapłanów dóbr, wyrażony w statucie 26, kłóci się z kompetencjami synodu plenarnego. Nie może on ograniczać zdolności w sprawie prywatnego kupowania dóbr ruchomych i nieruchomych, bo gdy kapłan skończy 21 lat nie jest juz pupillus ordinarii, chyba że nabywanie byłoby ze szkodą dla Kościoła lub kupno byłoby niegodziwe. Nie ma potrzeby zgody ordynariusza, gdyź ścieśnia się tu bez racji powszechną ustawę kościelną, a zgodnie z kanonem 1526 władza ordynariusza nie rozciąga się na sprawy prywatne kapłana. W razie konieczności ius naturale defensionis praevalet (od- 


\section{nia 1934) $)^{127}$, bp płocki (17 grudnia 1934) $)^{128}$, bp kielecki (24 grudnia}

nośnie do statutów 29 i 30). Paragraf 4 statutu 51 powinien przybrać sformułowanie: „przy pobieraniu opłat stuly proboszczowie winni kierować się roztropnością pasterską i miłością chrześcijańską”, a paragraf 5: „wykraczający przeciw przepisom o pobieraniu opłat stuły będą surowo karani”. Sprawa przymusowych oplat na rzecz samopomocy kapłańskiej kłóci się ze sprawiedliwością w wypadku kapłanów płacących składki do funduszu pensyjnego państwowego lub samorządowego oraz w ubezpieczalni społecznej. Należy to uwzględnić w sformulowaniach statutu 53. Brak jest jednolitych przepisów o udzielaniu jurysdykcji zakonnikom do spowiadania. Statut 77 został surowo oceniony, jako fatalnie zredagowany. W statucie 80 powinno się znaleźć wyjaśnienie kan. $98 \$ 1$ o przynależności do obrządku. Odnośnie do stosownego przygotowania do I Komunii św. Autorzy proponują dodanie do statutu $84 \mathrm{nr} 4$ słów: „dla umożliwienia kapłanom spełnienia tego obowiązku, biskupi uzyskają stosowne rozporządzenia władz szkolnych państwowych”.

W statucie 91 proponuje się wytłumaczenie dlaczego, pomimo kan. $823 \$ 2$ zabraniającego odprawiania Mszy św. „in Graecorum antimensis” kapłanom obrządku łacińskiego, w Polsce przepis ten nie obowiązuje. Jest to przywilej wyrażony w konstytucji Benedykta XIV „Inposito Nobis” z dnia 29.03 .1751 roku - $\$ 8$ oraz w dekrecie „Concordia” z 1863 roku punkt 13a. W statucie 93 proponuje się użyć: „muszą otrzymać władzę spowiadania od miejscowego ordynariusza” zamiast projektowanego: „muszą się zwrócić o udzielenie im władzy spowiadania". Odnośnie rozstrzygnięcia statutu 101 Autorzy stwierdzili jego niezgodność z przepisami dotyczacymi duchowieństwa wojskowego, zatwierdzonymi dnia 27 lutego 1926 roku przez nuncjusza Lauri'ego. Do statutu 104 zaproponowano dodać słowa: „oraz pouczać i nalegać ażeby małżeństwo zawierali przy mszy św. i podczas niej przyjmowali Komunię św.". W projekcie statutu 123 zawarto życzenie używania Rytuału w języku polskim; Autorzy wskazali, iż należy najpierw uwzględnić w większym stopniu język polski i następnie nakazać jego stosowanie w całej Polsce. Wobec dużych rozbieżności w poszczególnych dzielnicach co do melodii pieśni, kalendarza i wykazów świętych domagają się one ujednolicenia (do statutu 126 i 127). Ostatni postulat dotyczył obowiązku nauki katechizmowej dla młodzieży pozaszkolnej obejmującej 14-20 rok życia; propozycja dotyczyła statutu 139.

${ }^{127}$ AKS, t. 2, k. 92-93; nr 5093 - Kolejne wnioski przedstawil bp St. Kukomski (z dnia 10 grudnia 1934 r.). Jego list zawiera 4 strony. W statutach 1 i 5 zauważa niejednakową terminologię; raz używa się „po potwierdzeniu”, innym razem „po zatwierdzeniu”. Zdaniem bpa Lukomskiego lepszym określeniem jest to drugie ze względu na mająca nastąpić rewizję przez Stolicę Apostolską. By nie było niepotrzebnych konfliktów wynikających $z$ dowolnej interpretacji, należy do statutu 7 dodać zwrot: „specjalne prawa obrządków wschodnich”, a w statucie 12 zmienić słowa: „którego jest zwołujaçcy kongregację, na: „do którego należy zwołujacy kongregację”. Biskup w statucie 15 proponuje nowe sformułowanie: „każdy kapłan jest zobowiązany odprawiać co 3 lata rekolekcje wspólne, przynajmniej 3-dniowe w miejscu oznaczonym przez ordynariusza lub w domach rekolekcyjnych zakonnych". Nowego zredagowania domaga się również statut 15; powinno być: "nie wolno odprawiać mszy św. bez sutanny”. Zaproponował opracować ogólny przepis dla wszystkich diecezji dotyczący opłat iura stolae. Niezgodny z prawem cywilnym panującym w byłej Kongresówce jest zapis statutu 76, w którym znalazl się nakaz zapisywania do ksiagg metrykalnych dzieci ochrzczonych. Co do udzielania Komunii św. właściwym czasem jest wiek 9 lat. Biskup Lukomski uważa, że statut 91 jest sprzeczny z kanonem 823\$2, natomiast pomiędzy statutem 101 a 13 artykułem pkt b Statutu Duszpasterstwa Wojskowego. Jako nierealny został określony statut 131 dotyczacy zakazu koedukacji w szkołach powszechnych. 
$1934)^{129}$, kard. Kakowski (20 grudnia 1934) wraz z uwagami profesorów WSD warszawskiego i zarysem projektu synodu prowincjalnego dotyczącym spraw szkolnych ${ }^{130}$, bp Gall (16 listopada 1934) ${ }^{131}$,

${ }^{128}$ AKS, t. 2, k. 94-95, nr 3071 - Kolejnym wnioskodawcą był biskup płocki - J. A. Nowowiejski (z dnia 17 grudnia 1934 r.). Na początku swej wypowiedzi wyraził ubolewanie, że nie uwzględniono wcześniejszych jego postulatów i skreślono Aneksy bez głosowania. W uwagach szczegółowych stwierdził, że niewykonalne jest spisanie wykazu nieobowiązujących przepisów i zwyczajów diecezjalnych (odnośnie do statutu 2). Uważa, że nauczyciele religii powinni być uczestnikami kongregacji dekanalnych. W statucie 15 domaga się podkreślenia, że rekolekcje kapłańskie powinny być wspólnotowe. Odnośnie do wieku dopuszczenia do Komunii św. (statut 83) biskup proponuje uwzględnienie wskazań Stolicy Apostolskiej, które mówią o komunii prywatnej i solemnej; pierwsza miałaby miejsce w wieku 7 lat, solemna - okolo 12 roku życia. Autor poddaje pod dyskusję sformulowanie 101 statutu, stwierdzając błędne zestawienie koniecznej delegacji i biernej asystencji proboszcza i wikariusza - odsyła do Gasparri'ego De matrimonio nr 954. Również i biskup Nowowiejski poddaje w wątpliwość co do zakazu wyrażonego w statucie 131 uczenia dzieci w szkołach koedukacyjnych.

${ }^{129}$ AKS, t. 2, k. 96 - Liczące trzy strony uwagi nadesłał biskup kielecki (prawdopodobnie bp Łoziński, gdyż brak podpisu). Wnosi o przeredagowanie statutu 60; wzmianka o wyznawaniu wiary w życiu prywatnym nie ma racji bytu. Należy lepiej wyrazić tę myśl choćby „życie według wskazań wiary”. Statut 71, dotyczący sakramentów w ogólności, proponuje opuścić. Natomiast w statucie 86 Autor zauważa konieczność zmiany zachęty do binowania na nakaz binowania Mszy św.

${ }^{130}$ AKS, t. 2, k. 99-108 - Kolejny wniosek, to propozycje profesorów Wyższego Seminarium Metropolitalnego w Warszawie, podpisane przez kard. Kakowskiego. Liczą one 10 stronnic. W wielu wypadkach przepisy synodalne domagają się obostrzenia, szezególnie odnoszące się do życia kapłańskiego. Profesorowie proponują wskazać, które zwyczaje zachowane od niepamiętnych czasów należy utrzymać nadal w mocy prawnej (święta zniesione i zachowywanie postów). Statut mówiący o obowiązywalności uchwał synodalnych i dyspensowaniu od nich (6), pokrywający się z kan. 291§2, proponują opuścić. Profesorowie warszawscy proponują sięgnąć do uchwal synodów diecezjalnych kieleckiego i tarnowskiego odbytych w roku 1928 oraz do Odezwy do duchowieństwa Piusa XI Haerent animo z 24 sierpnia 1908 roku. Jednocześnie dopominają się wzmocnić nakazy dotyczace stroju kapłańskiego (statut 16) i realniejsze ukształtowanie statutu 17 odnośnie do tego obowiązku poprzez sformułowanie: spełniać jakiekolwiek czynności liturgiczne extra casum necessitatis". W statucie 21 Autorzy proponują szerzej uwzględnić kan. 1524, poruszając słuszną płacę kapłanów, higienę pracy i mieszkania, należny odpoczynek. Profesorowie twierdzą, że należy opuścić statut 24 zakazujący tańców i uczęszczania do restauracji z dancingami, gdyz wystarczająco mówi o tym kan. 140. W dalszej części wypowiedzi odnaleźć można pochwałę rozstrzygnięcia statutu 26 zakazującego nabywania nieruchomości przez kaplanów bez zgody ordynariusza. Statut 28 domaga się dokładniejszego określenia zakazu zajmowania się handlem, czy chodzi o handel na cele społeczne, czy na cele osobiste. Zauważono brak określenia stosunku kleru do polityki i partii politycznych. Pomocą służyć może orędzie papieża Benedykta $\mathrm{XV}$ z dnia 16 lipca 1921 roku wystosowane do episkopatu polskiego. Inne postulaty to obowiązek posiadania celebretu, zawiadamiania władz diecezjalnych o kuracji i przyjeździe kapłana na inne terytorium. Odnośnie do pracy i posługi duchowieństwa wskazano kilka postulatów; w statucie 34 proponuje się dodać by duchowni powiadamiali parafian 
ks. Gautier (bez datowania) $)^{132}$, ks. Bączkiewicz (21 listopada
$1934)^{133}$, bp Szlagowski (15 listopada 1934) $)^{134}$, ks. Infułat Brz..

o wystąpieniach Ojca św., encyklikach i innych wypowiedziach. W statucie 38 należy przypomnieć obowiązek modlitwy za swoich pasterzy. Profesorowie z zastrzeżeniem odnieśli się do statutu 41; domagano się podkreślenia, iż kolęda ma mieć charakter pasterskiej wizyty, odwiedzin parafian, dlatego niewskazane jest aby wikariusze (i tylko o nich mowa) przy ich okazji zbierali ofiary na wlasne potrzeby. Ponieważ statuty 47 i 32 są do siebie podobne, należy jeden z nich opuścić. Wśród obowiązków duchowieństwa szczególnie uwypuklono zadania związane z rozwojem działania Akcji Katolickiej. Jednocześnie warszawscy profesorowie, dbając o cnotę wikariuszy, domagają się by w statucie 48 wyrażono nakaz w stosunku do wikariuszy działania tylko w męskich organach tej organizacji. Ważnym społecznie postulatem było by do statutu 50 dodać wskazanie, ażeby przy parafiach byly utrzymywane szpitaliki, przytułki dla starców i sierot dotowane $z$ ofiar parafian i instytucji samopomocy spolecznej. Troska o wyraźną postawę w życiu publicznym czlonków Akcji Katolickiej, przynagliła profesorów do wskazania, iż w statucie 69 powinna się znaleźć prawda, iż w czasie wyborów samorządowych i ustawodawczych powinni oni zadbać o dobro Kościoła. Kodeksowe wyrażenia wydają się mieć inny wydźwięk aniżeli sformulowania statutów; dlatego profesorowie zaproponowali by spotęgować wyrażenie kodeksowe zawarte w kanonie 1060 zakazujące małżeństw mieszanych (zamiast statutowego obowiązku przestrzegania przed nimi). Podobnie zakazem powinno się wyrazić przestrzeganie przed małżeństwami z odstępcami od wiary i współpracującymi ze stowarzyszeniami potępionymi przez Kościól (zgodnie z dyspozycją kanonu 1065). Końcowy wniosek dotyczył ustalenia norm dla oplat w sądach kościelnych oraz zastạpienia adwokatów świeckich kapłanami (odnośnie do statutu 155).

${ }^{131}$ AKS, t. 2, k. 113; Wniosek bpa St. Galla (z dnia 16 listopada 1934 r.) odnosi się do kilku statutów. Postanowienia statutu 4 pokrywają się z dyspozycją kan. 5 CJC, dlatego proponuje ich opuszczenie. Należy zmienić brzmienie statutu 16 tak, by wyrażał, że nie wolno dopuszczać do ołtarza kapłana przebierającego się w strój świecki. Statut 46, zgodnie z opinią bpa Galla, jest zbyteczny, a 68 - niejasny. Wobec pokrywania się treści statutów 71 i 139, zaproponował opuszczenie jednego z nich; podobnie ze statutami 89 i 43.

${ }^{132}$ AKS, t. 2, k. 114-115 - Krótkie, ale rzeczowe uwagi przedstawił ks. Gautier. Najpierw ukazal parafrazy Kodeksu zamieszczone w statutach, np.: 60 odpowiada kan. $1325 \S 1 ; 66-1262 \S 2 ; 67$ i $70-684 ; 103-1108 ; 153-1353 ; 154-1563 \S 3 ; 164-1276-1278 ; 166-$ 1393. Niektóre statuty powtarzają zasady, które są elementarne: 6g, 81-92, 110-119. Następnie Autor wylicza statuty sprzeczne, jego zdaniem, z prawem kodeksowym: statut 93 jest niezgodny z kan. $873 \S 1$ oraz z kan. $881 \$ 1$ i $905 ; 101$ - z kan. $1095 \$ 1$ n. 2; 102 - z kan. 1024. Ks. Gautier dostrzegł też sprzeczne statutu z prawem cywilnym; statut 78 był niezgodny z przepisami dotyczącymi ksiąg stanu cywilnego, a 131 wobec przymusu szkolnego. Następnie Autor przystępuje do omówienia poszczególnych statutów. W statucie 16 sformułowanie „wystrzegać się” jest nieodpowiednie wobec kapłańskiego obowiązku noszenia sutanny. Natomiast statut 19, w Jego opinii, jest zbyt surowy. Zakaz przebywania kapłanów w restauracjach nie obejmuje wszystkich sytuacji, podczas których (wycieczki, pielgrzymki) potrzeba zmusza do przekroczenia zakazu. W projekcie statutu 29 proponuje po słowach: „ktokolwiek z duchownych” dodać słowa „w skutek karygodnej opieszałości". Jako tożsamy określa statut 47 i 32; z tym ostatnim proponuje połączyć statut 58 . Podobnie statut 71 jest identyczny z 139 oraz statut 89 i 43 . W statucie 62 o codziennym rozmyślaniu wiernych, dostrzega zbyt wygórowane wymagania. Wymienione w statucie 67 zagrożenia wiernych, wśród których wyliczono bolszewizm i socjalizm na 
z Warszawy (nazwisko nieczytelne; list datowany 24 październi-
$\mathrm{ka})^{135}$, profesorowie Wydziału Teologicznego UW (10 grudnia
$1934)^{136}$, wnioski z Krakowa ( 29 grudnia), arcbp Jałbrzykowski wraz

jednym poziomie, należy inaczej sformułować, gdyż bolszewizm jest tylko jedną z form socjalizmu. Statut 110 powinno się połączyć ze statutami $81 \$ 1$ i 82 . Należy opuścić część VII, statuty 110-119. Ostatni 166 statut, zdaniem ks. Gautier, jest zbyteczny.

${ }_{133}$ AKS, t. 2, k. 116 - Następnym wnioskodawcą był ks. Bączkiewicz (z dnia 21 listopada 1934 r.). Wskazał pokrywające się w treści statuty: 47 i 32, 139 i 71 oraz statuty pokrywające się z dyspozycjami kanonów: $60 \mathrm{z}$ kan. $1325 \$ 1$, $101 \mathrm{z}$ kan. 1095 . W statucie 5 należy zastąpić sformulowanie „nie będą” (dotyczy wydawania przez biskupów ustaw niezgodnych ze statutami) na „nie mogą". Odnośnie statutu 10 , odbywanie czterech kongregacji do roku Autor uważa za wygórowane żądanie. W statucie 12 proponuje podkreślić, iż kongregacje powinny być wspólne dla wszystkich obrządków obecnych na danym terenie. W kwestii zamieszkiwania kapłanów (statut19) ujęcie projektowe jest $z a$ ostre. Natomiast w statucie 22 należy dodać, iż chodzi tam o stałe zamieszkanie na plebani. Zdaniem Autora wniosku, za ostra jest dyspozycja statutu24, mówiącego o uczęszczaniu kapłanów do restauracji. Zly termin użyto w statucie 100; powinno być „objęcie” obowiązków, a nie „przyjęcie”. Zakaz szkół koedukacyjnych (statut 131) jest nierealny wobec istniejącego przymusu szkolnego.

${ }^{134}$ AKS, t., k. 118 - Dalsze wnioski sa autorstwa bpa A. Szlagowskiego (z dnia 15 listopada 1934 r.). Podobnie jak poprzednik, uważa, iż cztery kongregacje do roku to za dużo, stąd dyspozycja ta nie jest wykonalna. W statutach brakuje wyrażenia obowiązku modlitwy za zmarłych kaplanów. Skrupulatny biskup stwierdza, że w statucie 89 zbyteczne jest przypominanie o opalaniu kaplicy. Stwierdza, że dyspensowanie od przyjmowania Komunii św. na czczo, zawierajace się w statucie 103, jest dyspensowaniem od prawa ogólnego, anie jest to w kompetencjach synodu. Odnośnie do statutu 147 uznaje, iż nakaz gloszenia homilii po odczytaniu Ewangelii kłóci się ze zwyczajem.

${ }^{135}$ AKS, t. 2, k. 119 - Z Warszawy nadesłane zostały ( $\mathrm{z}$ dnia 24 października 1934 r.) wnioski spisane ręcznie. Trudno dociec nazwiska Autora - czytelne jest jedynie „Ks. Infułat Brz..”. Zwraca on uwagę, że w statucie 4 wystarczy domagać się jedynie dwóch kongregacji dekanalnych w ciągu roku. Kolejny raz odezwały się wątpliwości co do statutu 19, którego nakaz wspólnego zamieszkiwania kapłanów zostało określone jako trudne w zastosowaniu. Również kolejny raz stwierdzono, iż niejasny jest statut 22 . Autor negatywnie odnosi się do sformulowań, które zatracają charakter prawny statutów: „sprawy zalecane”, „pożądane”, „przypominane”. Należy je umieszczać w odsylaczach. Wnioskodawca ma wątpliwości czy do poświęcenia sztandaru szkolnego potrzebne jest pozwolenie aż ordynariusza (odnośnie do statutu 107). Proponuje skreślić statut 123 poruszający sprawę Rytuału oraz statut 126, mówiący o ułożeniu śpiewnika dla całej Polski, ze względów różnic dzielnicowych.

${ }^{136}$ AKS, t. 2, k. 120, nr 241 - Profesorowie Wydziału Teologicznego Uniwersytetu Warszawskiego: ks. Michalski, ks. Grabowski, ks. A. Borowski przesłali dość krótkie uwagi (z dnia 10 grudnia 1934 r.). Stwierdzają, iż materiał jest zbyt szczegółowy. Skoro jednostka prawną w Kościele jest diecezja obdarzona autonomią, stąd ustawy synodu plenarnego winny być jedynie ramowe. Profesorowie zarzucają projektodawcom chęć zniwelowania za wszelką cenę odrębności i poddania wszystkich objawów życia pod jeden strychulec, a właśnie to stanowi piękno bujnego życia. Domagają się uzasadnienia stosunku Kościoła do Państwa, wytycznych dla nauczania i prowadzenia seminariów, zasadnicze obowiązki uczących. Ostatnia, sarkastyczna uwaga stwierdza, że statuty synodalne nie powinny wyglądać jak kodeks karny dla duchowieństwa lub podręcznik ascetyczny. 
Z wnioskami Kapituły Metropolitalnej wileńskiej, WSD i Wydziału Teologicznego USB (25 października) ${ }^{137}$, bp tarnowski (31 grudnia), bp przemyski (31 grudnia), bp Szeptycki (30 grudnia), bp Twardowski (14 stycznia 1935 roku).

Projekt statutów synodalnych, których druga redakcja powstała po wrześniowej Konferencji Episkopatu, i których dotyczą nadesłane wypowiedzi, składał się z 15 działów zawierających następujące statuty:

I. Ogólne zasady - 7 artykułów,

II. Duchowieństwo w ujęciu ogólnym - 8-32,

III. Duchowieństwo w ujęciu szczególowym - 33-57,

IV. Zakonnicy - 58-59,

V. Laicy $-60-70$,

V.I. Sakramenty w ogólności - 71, w szczególności - 72-104, sakramentalia - 105-109,

V.II. Miejsca święte - 110-119,

V.III. Cześć Boża - 120-127,

IX. Nauczycielstwo - 128-150,

X. Seminaria duchowne - 151-154,

XI. Katolicki Uniwersytet Lubelski - 155,

XII. Beneficja - 156-162,

XIII. Sądownictwo - 163,

XIV. Proces beatyfikacyjny - 164,

XV. Prasa - 165-166 138 .

W dniach 15-17 lutego 1935 roku obradowała Komisja przygotowawcza w Warszawie pod przewodnictwem sekretarza Komisji

${ }^{137}$ AKS, t. 2, k. 123-125 - Uwagi nadesłane przez arcbpa Jałbrzykowskiego ( $\mathrm{z}$ dnia 25 października 1934 r.) składały się z trzech części. W pierwszej swoje stanowisko wobec nowego projektu wyrazili członkowie Kapituły wileńskiej. Odnośnie do statutu 74 wnosili, aby zwrócić się do Stolicy Apostolskiej o pozwolenie na urządzanie baptysterium na plebaniach. Należy koniecznie opracować jednostajne formuły zapisywania metryk (do statutu 78). Należy skreślić slowa: „pod grzechem ciężkim” w statucie 84, gdyż takiej sankcji nie ma nawet w kan. $854 \$ 5$ CIC. Stwierdzają, że przepis kan. $823 \$ 2$ zabrania odprawiać na antymensach Greków, dlatego należy zmienić statut 91. Przepisy o służbic kościelnej powinny się znaleźć w oddzielnym rozdziale (dotyczy rozbudowy statutów 111 i 112). Jako niewykonalny określono projekt stworzenia ogólnopolskiego śpiewnika (statut 126), podobnie statut 131 o zakazie szkół koedukacyjnych należy skreślić. W części drugiej wniosków utrwalono wnioski przedstawicieli Seminarium Duchownego. Pierwszy postulat dotyczy zmiany statutu 6, w którym jest mowa o dyspensowaniu od ustaw synodalnych; należy zmienić z „gravis causa” na „iusta et rationabilis”.

${ }^{138}$ AKS, t. 2, k. 77. 
i przy obecności (16 lutego) kard. Kakowskiego. Obecni byli: ks. Blericq, ks. Borkowski, ks. Gautier, ks. Gerstman, ks. Grabowski, ks. Prof. Hłynka, ks. Prof. Kałwa, ks. Prof. Michalski. W czasie trwania obrad dyskutowano nad projektami statutów Komisji ogólnej, projektem kardynała Prymasa, a także nadesłanymi uwaga$\mathrm{mi}^{139}$. Ponadto dodatkowo w dniach 7-9 marca 1935 roku dyskutowano i opracowywano projekty statutów. Nieobecny był ks. Prof. Hłynko, przybył natomiast ks. Prof. Roth. Projekt - uzupełniony i poprawiony - odesłano członkom Komisji ogólnej w dniu 13 marca $1935 \mathrm{roku}^{140}$.

Kolejne spotkanie Komisji ogólnej miało miejsce w Warszawie 22 marca 1935 roku. Obecni byli: kardynałowie Hlond i Kakowski, arcbp Nowowiejski, biskupi: Szelążek, Przeździecki i Lukomski. W toku dyskusji ustalono treść projektu statutów synodu plenarnego. Sekretarzowi zlecono dopracować go stylistycznie i dokonać tlumaczenia na język łaciński. Komisja złożona $z$ arcbpa Galla, bpa Szlagowskiego pod przewodnictwem kard. Kakowskiego miała dokończyć pracę nad ustaleniem testów lekcji, ewangelii i modlitw liturgicznych. Na pisemny wniosek kard. Hlonda kard. Kakowski miał rozesłać biskupom do 13 kwietnia projekt uchwał synodalnych. W końcu ustalono, iż biskupi swoje zdanie o projekcie statutów przedłożą na piśmie tak, by można było nad nimi dyskutować na Konferencji Plenarnej mającej się odbyć w maju 1935 roku $^{141}$.

25 marca 1935 roku rozesłano biskupom protokół uchwał Komisji ogólnej z dnia 22 marca oraz projekt statutów. Wkrótce nadesłane zostały uwagi od: bpa plockiego, bpa włocławskiego, przemyskiego i bpa polowego; jeszcze tego samego dnia poproszono bpa Szlagowskiego o poprawienie w statutach usterek gramatycznych i stylistycznych. Wykonał tę pracę, przesyłając poprawiony tekst 29 kwietnia. W tym samym dniu zwrócono się do ks. Edwarda Blericq’a z prośbą o przetłumaczenie tekstu projektów na język łaciński, a tekst łaciński przejrzeli i poprawili ks. prał. Borkowski, ks. prof. Grabowski i ks. prof. Roth.

W takim stanie rzeczy - na forum Konferencji Plenarnej odbytej w dniach 4-6 maja 1935 roku, której przewodniczył kard. Kakowski

\footnotetext{
${ }^{139}$ P. Kałwa, jw., s. 10.

${ }^{140} \mathrm{Jw}$.

${ }^{141}$ Jw., s. 7-8.
} 
- do projektu ustaw, który miał się stać podstawą obrad synodalnych, dołączono dalsze poprawki. Zatwierdzono także zapowiedziany wcześniej termin (29-31 sierpnia) odbycia synodu. W myśl rozporządzeń kodeksowych (kan. 281) zarządzono, iż pismo o pozwolenie na odbycie synodu oraz o wyznaczenie legata na synod a także, że projekty ustaw zawiezie do Rzymu bp Przeździecki ${ }^{142}$.

13 maja kard. Hlond skierował do kard. Kakowskiego list z prośbą o przesłanie biskupom tekstu statutów synodu plenarnego zatwierdzonego podczas ostatniej Konferencji Episkopatu. Przewodniczący synodalnej Komisji ogólnej uczynił to prosząc o nadesłanie ostatecznych uwag do dnia 1 lipca 1935 roku. Uwagi nadesłali: bp łucki, kard. Sapieha, metropolita lwowski obrządku łacińskiego, bp włocławski, tarnowski, piński, częstochowski, łódzki, bp Bromboszcz, administrator apostolski Diecezji sandomierskiej, bp przemyski, bp sufragan sandomierski. Nadszedł też jeden list bez podpisu ${ }^{143}$.

Wspomniany wcześniej termin odbycia synodu uległ kolejnej nowelizacji ze względu na chorobę kard. Hlonda i jego wyjazd na leczenie do Ljubljany. Na wniosek sekretarza - bpa Przeździeckiego, pismo do Świętej Kongregacji Soboru powinien podpisać nie tylko kard. Kakowski, lecz również kard. Hlond. Domagala się tego ważność sprawy. Z prośbą w tej sprawie Biskup Przeździecki dnia 10 maja 1935 roku zwrócił się telegraficznie do nieobecnego w kraju Prymasa $^{144}$. W tym też czasie bp Przeździecki wyjechal do Rzymu w celu usprawiedliwienia zatwierdzonego już terminu obrad synodalnych, wziąwszy winę na siebie.

Do końca roku 1935 odbyły się jeszcze dwie konferencje Komisji ogólnej i nadzwyczajnej. Pierwsza - w dniach 12-15 listopada, druga 18-20 grudnia 1935 roku. Na posiedzeniu Komisji synodalnej byli obecni: kard. Hlond, kard. Kakowski, arcbp Sapieha, Jałbrzykowski, bp Lisowski, Przeździecki, którzy przyjęli referat Rzut oka na prace przygotowawcze synodu plenamego, autorstwa ks. prof. Kalwy. Po dyskusji nad wnioskami ordynariuszów postanowiono wydać list pasterski omawiający najważniejsze sprawy związane $\mathrm{z}$ synodem. Poprawiony tekst projektu postanowiono oddać w ręce, powolanych z każdej metropolii, duchownych prawników, by dokonać sto-

\footnotetext{
${ }^{142}$ KE 14, Konferencja Episkopatu Polski 4.05.1935, k. 10.

${ }^{143}$ P. Kałwa, jw., s. 10.

${ }^{144} \mathrm{Jw}$.
} 
sownych poprawek pod względem prawnym. Na zapoznanie się z projektem przeznaczono jeden miesiąc. Postanowiono zachować przyjęty podzial materiału, a opatrzyć statuty wstępem podjął się kard. Hlond. Zdecydowano się zamiast terminu „statut” używać terminu „przepis”. Jeszcze w godzinach przedpołudniowych rozpatrzono piętnaście pierwszych przepisów. Po południu do dyskusji dołączyli prawnicy: ks. kan. Blericq, ks. prał. Grabowski, ks. prał. Borkowski, ks. prał. Gautier, ks. prał. Gerstman, ks. prof. Hłynka, ks. prof. Kalwa, ks. prof. Michalski, ks. prof. Roth. Wspólnie rozważano przepisy 42-131. Końcowe przepisy - od 132 - byly poddane dyskusji na posiedzeniu w dniu 13 listopada. Do grona prawników, biorących udzial w dotychczasowych dyskusjach, postanowiono dołączyć ks. Prał. St. Bolandę z Tarnowa oraz ks. Kanonika Leona Żebrowskiego z Wilna. W tak poszerzonym składzie miały się odbyć narady w dniach 18-20 grudnia tegoż roku. Dosyć szybko wydrukowano projekty przepisów i rozesłano po 10 egzemplarzy członkom komisji i metropolitom, którzy to mieli spotkać się na posiedzeniu Komisji po 14 stycznia 1936 roku $^{145}$.

W międzyczasie nadchodziły także uwagi osób świeckich. Z Tarnowa przysłał list Władysław Bród, w którym przedstawił problemy organistów. List zawieral też prośbę o rozwiązanie tych problemów ${ }^{146}$. W imieniu Katolickiego Związku Kobiet swoje uwagi przesłała jego Prezeska, szczególnie akcentując sprawy związane z Akcją Katolicką ${ }^{147}$. Bliski współpracownik i przyjaciel kard. Hlonda -

${ }^{145}$ AKS, Projekty statutów synodalnych. Protokół posiedzeń Komisji Synodalnej powołanej uchwała Komisji Prawnej. Posiedzenie 12 listopada 1935 r.

${ }^{146}$ AKS, Akta Synodu I Plenarnego. Korespondencja od 12.02.1936 do 5.04.1939, k. 2, s. 4. List, liczacy 4 strony, wysłany 10 stycznia 1936 roku przez organistę katedralnego byl nie tylko ukazaniem problemów środowiska organistowskiego, ale również wskazywał propozycje ich rozwiązania. Wzorem rozwiązań zastosowanych na Górnym Sląsku, gdzie organista jest jednocześnie nauczycielem, co rozwiązuje kwestię jego utrzymania. Bezzwłocznie należy tworzyć średnie szkoły zawodowe organistowskie i 5 letnie seminaria nauczycielskie. Powinna powstać też wyższa szkoła państwowa, gdzie po średniej szkole można by było kształcić organistów, profesorów i dyrygentów.

${ }^{147}$ Jw., k. 4. Rozbudowane na 12 stron maszynopisu wnioski, podpisane prawdopodobnie przez Panią Raperską, nie posiadają żadnego datowania. Jej uwagi są bardziej praktyczne aniżeli prawne. W statucie 18 proponuje podkreślić potrzebę kapłanów-ascetów, którzy wykazywać się będą większą kulturą serca. Potępiając zbytkowny styl życia kapłanów, wskazuje na konieczność zakazu wystawnych obiadów odpustowych. Odnośnie do statutu 37 zauważa, że należy w nim wyrazić powinność tworzenia w kuriach działów: duszpasterskich, nauczania religii, Akcji Katolickiej, charytatywnych 


\section{profesor Uniwersytetu Poznańskiego - Stefan Dąbrowski ${ }^{148}$, prezes}

i majątkowych. Z perspektywy wiernych zadaje pytanic czy leży w interesie Kościoła, aby proboszczowie byli nieusuwalni - odnośnie do statutu 44. Domaga się umieszczenia w statucie 48 wyraźnego nakazu posiadania przez każdą parafię organizacji Akcji Katolickiej. Wobec nieuregulowania sprawy stypendiów mszalnych zaleca ustalenie ich minimalnej wysokości (statut 53). Autorka ma zastrzeżenia co do zakładania odrębnych zrzeszeń przez zakony wychowawcze, co może wytworzyć specyficzną kastowość wśród inteligencji (odnośnie do statutu 61). W statucie 72 proponuje dodanie: „synod zaleca przynależność i czynną pracę w Akcji Katolickiej”. Należy wyraźniej potępić błędy i sprecyzować pozytywną naukę Kościoła odnośnie do nowych prądów politycznych w statucie 74. W następnym statucie należy wyrazić myśl, że nie zaleca się przynależności do partii socjalistycznych oraz wytknąć idealizowanie bolszewizmu. Wobec zagrożeń zwykłą ludzką zachłannością Autorka proponuje w statucie 77 umieścić uwagę, iż pożądane jest, aby parafianie mieli wgląd w zużytkowanie ofiar i składek. W statucie 78 wyraźnie należy określić władze Akcji Katolickiej i ich kompetencje.

${ }^{148} \mathrm{Jw} ., \mathrm{nr} 2$. W liście bez datowania liczącym 6 stron Autor odnosi się tylko do dwóch tematów: „Księża Prefekci” z III rozdziału oraz statuty 75 i 86 dotyczące wiernych. Prawdopodobnie uwagi te stały się podstawą opracowania zagadnienia nauczania religijnego w Polsce, które wygłosił kard. Hlond podczas dyskusji w gronie kardynałów w Watykanie w maju 1937 roku. Prof. Dąbrowski stwierdza, iż kontakt prefektów z młodzieżą w wyższych klasach szkół średnich jest niewystarczający. Jest to wynikiem ustawy zwanej jędrzejowiczowską o reformie szkolnictwa, która rozbiła dawne ośmioletnie gimnazjum na trzy fragmenty stanowiące odrębne środowiska (szkoła powszechna, skrócone gimnazjum i liceum). Taka sytuacja sprawia przerwanie ciągłości wpływu prefekta na młodzież. Reforma Jędrzejewicza, co wykazal poseł prof. St. Stroński, dąży do tego by prefekt nie miał dostatecznej ilości godzin do stałego etatu, przez co nie będzie mógł zasiadać w gronie nauczycielskim. Daje to w efekcie ograniczenie wpływu na grono nauczycielskie i sprawy tyczące się wychowania młodzieży. W miastach uniwersyteckich pożądana jest współpraca między kołem profesorów szkól średnich a duszpasterzem akademickim; należy wydać przepis o takiej wspólpracy. Autor proponuje dodanie nowego ustępu o duszpasterstwie akademickim, ponieważ to duszpasterstwo nie może być traktowane dorywczo i nie może być improwizowane na mocy inicjatywy osobistej. Tłumaczy tę konieczność falą nowych prądów myślowych: „zaczepny ruch bezbożniczy, bolszewicki ateizm, hitlerowski achrystianizm". Sprawa ta jest o tyle niebagatelna, że w roku 1933-34 studiującej młodzieży było 49.725 osób, z czego $69 \%$ to mężczý́ni i $31 \%$ kobiet. Prof. Dąbrowski z zastrzeżeniem odniósł się do statutu 75, w którym wysunięto pojęcie państwa z pominięciem pojęcia narodu i społeczeństwa, np. statut $75 \$ 1$ - „w stosunku do Państwa Polskiego powinni katolicy...”. W drugim paragrafie tegoż statutu proponuje zmianę: zamiast „opierając się współczesnym błędom w tej dziedzinie będą się m.in. przeciwstawiać kierunkom politycznym, które ubóstwiaja państwo" wstawić „przez oddziaływanie na opinię publiczną i czynny udział w życiu politycznym”. Treść taką dyktują zmiany w nauczaniu Kościoła odnośnie uczestnictwa akatolików w działaniach politycznych. Tymezasem w warunkach polskich uważana jest za niegodna współdziałania co nie koresponduje z najnowszymi wypowiedziami papieskimi (Pius XI w liście do Prymasa Portugalii w 1934 roku podkreślał, że Akcja Katolicka jest między innymi szkołą dobrej polityki i mają obowiązek brać udział w życiu politycznym kraju). Odnośnie statutu 86, który wspomina o misji żydowskiej, proponuje skreślenie. Tłumaczy to możliwością niezrozumienia przez społeczeństwo, które może odczuć to jako zagrożenie dla społeczności polskiej. Chęć powoływania specjalnych struktur prawnych w tym 
Naczelnego Instytutu Akcji Katolickiej - hrabia Bniński ${ }^{149}$, prezes Katolickiego Związku Mężczyzn - p. Potworowski ${ }^{150}$, książe Witold Czartoryski $^{151}$, p. Mieczysław Chłapowski ${ }^{152}$ oraz profesorowie pra-

zakresie może spowodować (tak, jak w Hiszpanii) pozorne nawrócenia Żydów stanowią-
ce narzędzie wpływów judaizmu wewnątrz społeczności katolickiej.
${ }^{149} \mathrm{Jw}$., liczba 3. List datowany był w Gułtowach 15 grudnia 1935 roku. Autor zadaje
pytanie co oznaczają „stosunki towarzyskie”, których zabrania się najpierw duchow-
nym (rozdz. II przepis 17), a potem wiernym (rozdz. IV przepis 70 ). Odnośnie rozdzia-
łu V o Akcji Katolickiej stwierdza, iż powinna być ona podporządkowana jedynie pry-
masowi, gdyż biskupi nie zawsze lojalnie działają w stosunku do uzgodnionych na kon-
ferencjach Episkopatu dróg. W rozdziale VI przepis 91 polecającym zakładanie biblio-
tek, proponuje dodać: ,a tam, gdzie są umocnić wpływy katolickie”.

${ }^{150} \mathrm{Jw} ., \mathrm{nr} 5$. W liście brak datowania. Autor zwraca uwagę na konicczność umieszczenia w przepisie 22 napomnienia o unikaniu partyjności i klasowości. Szambelan Potworowski stwierdza, że w przepisie 45 brakuje ukazania sposobu wykonywania kolędy. W dalszej części wniosków wysuwa propozycję dodania w przepisie 69 wzmianki o obowiązku pracodawcy opicki moralnej nad domownikami i pracobiorcami. Zwracając się ku zachowaniach wiernych w kościele, proponuje dodać do przepisu 95 wzmiankę o wymogu punktualności w kościele, a do przepisu 100 o unikaniu pośpiechu w słuchaniu spowiedzi i masowego jej słuchania. W stosunku do kapłanów podnosi kwestię konieczności postawienia wymogu w ramach przepisu 135 sprawy starannego przygotowania kazań. Racjonalnie podchodzac do możliwości ekonomicznych Kościoła polskiego, stwierdza, że tworzenie specjalnych domów rekolekcyjnych jest zbyt kosztowne i należy je zastąpić domami zakonnymi.

${ }^{151} \mathrm{Jw} ., \mathrm{nr} 6$. Uwagi nadesłane w styczniu 1936 roku odnoszą się do kilku rozdziałów projektu uchwał synodalnych. Ksiąze Czartoryski wskazał, iż w rozdziale trzecim należy silniej podkreślić obowiązek prefektów takiego działania i osobistego kontaktu wychowawczego w szkole i poza nią z młodzieżą, by jej przechodzenie ze szkół niższych szczebli do wyższych pozwalało na ciagłość wychowywania. W stosunku do młodzieży akademickiej należy podejmować działania takie by stały się one podwaliną pracy dla narodu.. Zdaniem Autora należy w rozdziale XII napomnieć by na zebraniach, w prasie i w urzędach bardziej przejawiał się duch katolicki. Odnośnie do artykułu $157 \$ 2$ w rozdziale XIII należy dodać, iż wyklucza się możliwość wydzierżawiania i sprzedaży wł̣sności kościelnej niekatolikom i nie Polakom. Księża nie powinni kupować niczego od Żydów, ani im cokolwiek sprzedawać. Co do zagadnień zwiazanych z Zydami, w artykule 86 (rozdz. VI) stwierdzat, iz istnieje wciąż niebezpieczeństwo ich pozornych nawróceń (co jest historycznie uzasadnione - vide Hiszpania). Dlatego należy dogłębnie weryfikować takie nawrócenia i tylko indywidualne, przy osobistym przekonaniu kapłana o ich szczerości i bezinteresowności.

${ }^{152}$ Jw., nr 7. Uwagi datowane 01 stycznia 1936 roku w Kopaszewie. Autor domaga się by w art. $45 \$ 2$ zobowiązać duchowieństwo do składania radom parafialnym w sposób publiczny sprawozdań z zużycia kwot ze składek, kwest. W rozdz. IV, art. 76 należy sprecyzować obowiązki moralno-społeczne wiernych. M. Chłapowski stawia zarzut, że w rozdz. V za mało uwypuklono, że Akcja Katolicka jest przede wszystkim terenem działań wiernych świeckich. W rozdz. VII, art. 91 wskazał, że nie trzeba tworzyć osobnych bibliotek parafialnych tam, gdzie funkcjonują publiczne; należy je zasilić dziełami religijnymi. W rozdz. XI, w art. 122 należy sugerować ułatwienia w osiągnięciu przywileju przechowywania na stałe Najświętszego Sakramentu w kaplicach oraz nabożeństw w kościołach odległych od parafialnych. Natomiast w art. 124 należy wymienić wszystkie nabożeństwa w ciągu roku. 
wa przy Uniwersytecie Poznańskim (pp. Kasznica, Lisowski, Silnicki, Winiarski), to kolejni wnioskodawcy przedstawiający ważne problemy życia kościelnego w Polsce ${ }^{153}$.

W dniach 18-20 lutego 1936 roku zebrała się Komisja synodalna, na której obecni byli: kard. Hlond, arcbp Sapieha, Jałbrzykowski, bp Lisowski, Przeździecki. Podczas trwania tego posiedzenia rozważano nadesłane uwagi. Powzięto także następujące postanowienia:

- zmieniono nazwę ,przepis” na „artykuł”,

- nadano nazwę przyszłemu synodowi: „pierwszy Synod Plenarny w Rzeczypospolitej Polskiej”,

- przejrzano artykuły, które w ujednostajnionej redakcji sekretarz miał przekazać prawnikowi i styliście dla poczynienia poprawek,

- zobowiązano sekretarza bpa Przeździeckiego do przekazania w terminie do 1 kwietnia 1936 roku wszystkim biskupom protokołu $\mathrm{z}$ tego posiedzenia oraz nowego projektu; odbiorcy do dnia 1 maja mieli odesłać swoje ewentualne uwagi na adres Biura Episkopatu,

- sekretarz Komisji miał przygotować pismo skierowane do Ojca św. z prośbą o zgodę na zwołanie synodu i o mianowanie swego legata, zawierające krótki rys prac synodalnych i uzasadnienie uchwal, które są praeter legem,

- zdecydowano, iż na Konferencji Episkopatu, projektowanej na miesiąc maj, będą referowane poszczególne części projektów przepisów synodalnych. Kardynałowi Prymasowi przypadło w udziale przedstawić ogólny rzut oka na prace przygotowawcze oraz I i II rozdział, arcbpowi Sapieże - rozdzial III, arcbpowi Jałbrzykowskiemu - rozdziały IV, V, VI, VII, biskupowi Lisowskiemu - rozdziały VIII, IX, X, XI, a biskupowi Przeździeckiemu - XII, XIII,

${ }^{153} \mathrm{Jw}$, nr 1. Autorzy zarzucają projektom małą ścisłość językową i brak precyzji ujęć prawniczych, a miejscami nieszczęśliwą stylistykę. Noeologizmem jest nazywanie uchwał synodalnych „przepisami”; powinny być albo artykuły, albo paragrafy. Innym mankamentem jest występowanie ustępów apelujących do strony emocjonalnej (np. 12, $31,58,145)$. Prawo używa zwrotów: nakazuje, zakazuje, dozwala, a w projektach pojawiają się zwroty nieprawnicze: „poleca się”, ,goraco, usilnie przypomina”, „kładzie nacisk" - sa to nieodpowiednie, niejasne wyrazenia. Kolejnym zarzutem jest powtarzanie się przepisów kodeksowych (np. 8, 16, 23, 24, 39, 41, 44, 55, 154). W art. 153b ujawnia się sprzeczność z Kodeksem: fundacja nie jest osobą prawną, lecz stanowi donatio sub modo, tzn. darowiznę ze zleceniem uczynionym na rzecz jakiejś osoby prawnej. W art. $164 \$ 2$ zasugerowano, iż możliwość pozywania przed sądy świeckie kapłanów za pozwoleniem biskupa idzie dalej niż Konkordat - tworząc privilegium fori. W art. $140 \mathrm{za}$ niewykonalne oznaczono pisanie tekstów kazań, a odnośnie do art. $14 \S 2$ sankcja suspensy latae sententiae za przebieranie się kapłanów jest zbyt wysoka. 
XIV i XV. Ten ostatni dnia 22 marca 1936 roku rozesłał projekt wraz z protokołem posiedzenia wszystkim biskupom ${ }^{154} .16$ marca 1936 roku kard. Hlond przesłał wstęp do uchwal synodalnych ${ }^{155}$.

Ostatnia, przedsynodalna Konferencja Episkopatu odbyła się w dniach 26-28 maja 1936 roku w Warszawie. Gotowy projekt statutów poddano kolejnej dyskusji ${ }^{156}$. Jeszcze w czasie trwania konferencji, 27 maja, wystosowano list z prośbą o zgodę na zwołanie synodu i o mianowanie legata - zgodnie $\mathrm{z}$ decyzją Komisji synodalnej z dnia 20 lutego. Na dzień 3 lipca 1936 roku zwołano posiedzenie specjalnej Komisji synodalnej do Poznania.

Zgodnie z ustaleniami, 3 lipca do Poznania przybyli bp Lisowski i bp Przeździecki, był obecny również kard. Hlond. Nie przybyli arcybiskupi Sapieha i Jałbrzykowski. Stosownie do zaleceń majowej konferencji, przejrzano uwagi i wprowadzono małe poprawki do projektu, i tak poprawiony projekt postanowiono wydrukować w języku polskim i łacińskim i rozesłać ordynariuszom w pięciu egzemplarzach. Zdecydowano zaproponować legatowi papieskiemu, aby zawezwał na synod oprócz ordynariuszów także pozostałych biskupów mieszkających na terenie Rzeczypospolitej, po jednym delegacie z każdej kapituły katedralnej, po jednym delegacie z Katolickiego Uniwersytetu Lubelskiego i czterech wydziałów teologicznych przy uniwersytetach państwowych oraz wszystkich ordynariuszów zakonnych, mieszkających w granicach Rzeczypospolitej wszystkich obrządków. Postanowiono również, iż sekretarz zawezwie na synod trzech prawników, trzech teologów i trzech natariuszów. Zlecono, także sekretarzowi, przeprowadzenie rozmów z generałem oo. paulinów co do odbycia synodu plenarnego na Jasnej Górze w dniach 25 i 26 sierpnia 1936 roku $^{157}$.

Po tym posiedzeniu kard. Hlond wyjechał na kurację do francuskiej miejscowości Bagnoles de l'Orne. Stamtąd kierował nadal pracami przygotowawczymi. Znajdujące się w Archiwum Siedleckim dokumenty ukazują cały szereg listów pisanych do kardynała Marmaggi'ego oraz innych polskich biskupów. 21 lipca 1936 r. Kar-

${ }^{154}$ KE 14, Posiedzenie Komisji Synodalnej 18-20.02.1936, k. 1-2, pkt 6; AKS, jw.

${ }^{155}$ AKS, Akta Synodu I Plenarnego, jw.

${ }^{156}$ KE 14, Konferencja Plenarna Episkopatu Polski 26.06.1936, k. 2-3.

${ }^{157}$ AKS, Akta Synodu I plenarnego. Materiały dotyczące protokółu oraz wnioski na synod, bez oznaczeń, jw. 
dynał przesłał bpowi Przeździeckiemu wiadomość, że Papież zaaprobował datę odbycia się synodu zaproponowaną przez Konferencję Episkopatu. W związku z tym też wysłał do wszystkich biskupów powiadomienia o spotkaniu biskupów w dniu 24 sierpnia o godz. 10 na Jasnej Górze. Nadmienit, iż wraca do Poznania 10 sierpnia. Bp Przeździecki odpisał na ten list 25 lipca z Siedlec (nr 3809); stwierdził w nim między innymi, iż przesłał już biskupom projekty uchwał w 5 egzemplarzach. Informował także, że wykonując zlecenie poprzedniego posiedzenia, uzgodnił z o. Piusem Przeździeckim (przeorem jasnogórskim), iż spotkają się w Warszawie 29 lipca celem omówienia spraw związanych z odbyciem się synodu na Jasnej Górze.

28 lipca nadszedł z Bagnoles do Siedlec telegram, w którym kard. Hlond przesłał pierwsze dyspozycje Legata i zaproponował spotkanie Komisji ogólnej w Poznaniu na dzień 12 sierpnia. Kolejny telegram nadszedł następnego dnia, 29 lipca, w którym zawierała się propozycja ogłoszenia triduum modlitw $w$ intencji synodu $w$ dniach od 24 do 27 sierpnia. Bp Przeździecki 29 lipca wysłał telegram do kard. Hlonda o zgodzie na termin spotkania Komisji wyznaczony przez niego, tzn. na 12 sierpnia. Sekretarz Komisji synodalnej listem (nr 1329) z dnia 29 lipca 1936 roku zwraca się do biskupów ordynariuszów, rektora KUL oraz dziekanów Wydziałów teologicznych uniwersytetów w Warszawie, Wilnie, Lwowie i Krakowie o wyznaczenie przedstawicieli kapituł katedralnych, KUL i Wydziałów uniwersyteckich. Nie było jeszcze w tej sprawie odnośnego rozporządzenia Legata, lecz bp Przeździecki chciał w ten sposób uprzedzić je, by gdy tylko legat zatwierdzi nominacje i zdecyduje o uczestnictwie quam primum wysłać stosowne zaproszenia. Ten niezmordowany biskup, 31 lipca rozesłał do wszystkich biskupów list (nr 1326), w którym pisze, że kardynałowie Kakowski i Hlond uważają, iż należy zwrócić się do katolików Rzeczypospolitej z zawiadomieniem o mającym się odbyć synodzie i wezwać ich do modlitwy w intencji pomyślnych obrad synodu. Przesłał też specjalną odezwę o mającym się odbyć triduum. Tego samego dnia (31 lipca) nadszedt list od kard. Hlonda, którym zwoływał posiedzenie Komisji synodalnej na wspomniany termin - 12 sierpnia, lecz nie do Poznania, ale do Biura Episkopatu. W liście tym odczytać można także notatkę, iż tlumaczenie projektu na łacinę wymaga drobnych poprawek. W międzyczasie do Kurii siedleckiej nadeszła przesylka z Kurii Metropolital- 
nej w Warszawie, zawierająca kopię odezwy Nuncjatury (datowanej 24 lipca 1936 r., nr 13612) w sprawie synodu plenarnego i mianowania przez Ojca św. legatem kard. Marmaggi'ego (datowana 29 lipca, nr 4273). Pismo Nuncjatury było podpisane przez Alfreda Paccini'ego na polecenie kard. Eugenio Pacelli'ego. Ogłoszenie nazwiska nominata miało nastąpić następnego dnia.

Wyrazem pracowicie spędzonego odpoczynku w Bagnoles przez kard. Hlonda, jest kolejny list wysłany przez niego 2 sierpnia do bpa Przeździeckiego, w którym powiadamia, że legat przyjedzie 23 sierpnia wraz ze swoją świtą złożoną z 10 osób. Napisał również list do bpa Adamskiego, bpa Kubiny i o. Piusa Przeździeckiego, by przygotowali w Katowicach i w Częstochowie stosowne przyjęcie legata. Z Jego upoważnienia poleca zaprosić 3 teologów, 3 prawników, 3 notariuszów i dyr. Ks. Brossa. Nadmienil, że powraca do kraju 8 sierpnia. W dwa dni później kardynał napisał następny list (datowany 4 sierpnia), w którym przesyła odpis dekretu konwokacyjnego.

31 lipca Episkopat wystosował odezwę i list pasterski w sprawie synodu do wiernych. Odezwa nawoływała do modlitw w intencji synodu, natomiast list jest wyrazem troski biskupów o naród polski, który zagrożony był wpływami radykalizmu i agitującego komunizmu międzynarodowego, którego efekty doświadczyć można było szczególnie dotkliwie na ziemi hiszpańskiej. Stąd Episkopat przestrzegał naród, który choć „w głębi duszy zacny i religijny, jest jednak często pozbawiony opieki i pomocy światłych warstw społeczeństwa i jest nieraz wydany na pastwę agitatora komunisty, który odbiera wiarę, sieje nieufność a po tym nienawiść do Kościoła, jak i do społeczeństwa, a w końcu do narodu i Państwa" ${ }^{158}$.

Dnia 1 sierpnia 1936 roku Ojciec św. Pius XI, w odpowiedzi na prośbę biskupów polskich $z$ dnia 27 maja 1936 roku, przesłał na ręce kard. Franciszka Marmaggi'ego breve mianujące go legatem na synod. Procedura ta zgodna była $\mathrm{z}$ praktyką usankcjonowaną przepisami Kodeksu Prawa Kanonicznego (kan. 281) ${ }^{159}$. Potwier-

${ }^{158}$ List pasterski Biskupów Rzeczypospolitej z Jasnogórskiego Synodu plenarnego. „Wiadomości Archidiecezjalne Warszawskie” 26 (1936) nr 9, s. 383.

${ }^{159}$ „Ordinarii plurium provinciarum ecclesiasticarum in Concilium plenarium convivere possunt, petita tamen venia a Romano Pontifice, qui suum Legatum designat ad Concilium convocandum eique praesidendum". 
dzeniem nominacji kard. Marmaggi'ego było pismo opatrzone numerem 13612 Nuncjatury Apostolskiej, wysłane w Warszawie dnia 24 lipca 1936 na ręce kard. A. Kakowskiego. Wspomniane breve wskazywało na konieczność odbycia takiego synodu w Kościele lokalnym obejmującym swoim działaniem ziemie Rzeczypospolitej, które „przechodziły tak różne koleje i tak odmiennie się kształtowały pod brzemieniem nieszczęść dziejowych"160. Papież zwrócił uwagę na to, że troska biskupów polskich obejmuje nie tylko ujednostajnienie karności i pracy kościelnej w Polsce, ale sięga także do zaktywizowania ludzi świeckich poprzez działania podejmowane przez Akcję Katolicką. Ten kierunek działań zyskał aprobatę, wskazując na dalekowzroczność posunięć ówczesnego Episkopatu.

5 sierpnia bp Przeździecki wystosowal list do prepozyta Nuncjatury (nr 3996/36), w którym informował o włączaniu się biskupów obrządku greko-katolickiego w przebieg prac synodalnych a właściwie o ich nieangażowaniu się w nie. Jest to odpowiedź na pismo z dnia 3 sierpnia (nr 13617). Sekretarz Komisji synodalnej chronologicznie przedstawił starania Episkopatu łacińskiego o to, by biskupi obrządku greko-katolickiego brali udział w synodzie. Przypominał, że zwołanie synodu plenarnego zaproponowano we wrześniu 1928 roku na Zjeździe Biskupów w Gnieźnie. Zjazd od początku miał na względzie to, by był to synod biskupów wszystkich obrządków w Rzeczypospolitej. 19 marca 1930 r. postanowiono zasięgnąc opinii Stolicy Apostolskiej na ten temat. 4 stycznia 1931 roku bp Szeptycki przesłał swoją opinię oraz opinie innych biskupów tego obrządku co do przeszkód w uczestniczeniu w synodzie. Dnia 25 marca 1931 r. Nuncjusz przesłał list, w którym wyłuszczał racje konieczności uczestniczenia w synodzie biskupów wszystkich obrządków. Komisja synodalna 26 sierpnia 1931 postanowiła, aby wszystkie dokumenty synodu plenarnego były przesyłane biskupom wszystkich obrządków. O tym także powiadomiony byl Nuncjusz listem z dnia 27 sierpnia 1931 roku. 10

${ }^{160}$ Breve Ojca św., Archiwum Kongregacji dla Duchowieństwa. Sygn. 4405/36. Pismo Piusa XI do kard. Marmaggi'ego 1.08.1936; tekst polski: „Wiadomości Archidiecezjalne Warszawskie” 26 (1936) nr 9, s. 379-380; zob. także W. Góralski, Przebieg pierwszego polskiego synodu plenarnego (1936) w świetle protokołu synodalnego, AK 79 (1987), s. 336. 
września 1931 r. bp Szeptycki dziękując za przesłane dokumenty zapewniał, iż biskupi obrządku greko-katolickiego wezmą udział w synodzie. 18 października 1934 roku Nuncjusz zapytywał o stan rzeczy w tym zakresie, na co odpowiedź otrzymał dnia 27 tegoż miesiąca. W komisjach specjalnych biskupi wymienionego obrządku nie brali żadnego udziału, poza udziałem ks. prof. Hłynki w posiedzeniu Komisji przygotowawczej w Warszawie odbytej w dniach 15-17 luty 1935 roku.

W odpowiedzi na pismo sekretarza bpa Przeździeckiego z dnia 20 lipca 1936 roku nadchodziły kolejne wnioski i uwagi. Nadesłali je: administrator apostolski diecezji sandomierskiej (10 sierpnia $)^{161}$, biskup płocki (3 sierpnia) ${ }^{162}$, Kuria Metropolitalna krakowska (bez datowania $)^{163}$, drugi list bpa płockiego z tego samego dnia co wyżej ${ }^{164}$,

${ }^{161}$ Biskup Jan Lorek w swoim liście (nr 3028/36) proponuje dodać odnośnic do art. 45-47, iż prefekci pracujący na terenie parafii podlegają miejscowemu proboszczowi. Pomiędzy artykułami 51-53 należy umieścić artykuł o zgromadzeniach i zakonach ukrytych. W art. 62 b dodać: „i w radio”, a w $103 \S 2$ opuścić: „zasadniczo”. Kolejny postulat odnoszący się do art. 123 i 124 wnosi by podkreślić w nich konieczność głoszenia przez kaznodziejów jak najczęściej o świętości Kościoła i powadze widzialnej Jego Glowy papieża. Ostatnia uwaga dotyczy podkreślenia, iż wszelkie dzierżawy można oddawać jedynie za pozwoleniem władzy diecezjalnej (odnośnie do art. 141\$2).

${ }_{162}$ Arcbp Nowowiejski (list nr 2774) żąda wykreślenia art. 109, mówiącego o konieczności opracowania i wydania Rytuału, ze względu na niestosowny czas. Jest już za późno i dyspozycja byłaby niezrozumiała.

${ }^{163}$ Wnioski dotyczą pięciu artykułów. Odnośnie art. $26 \$ 3$ należy dodać, iż biskupi zobowiązują się zwracać do Konferencji Biskupów i jednolicie postępować. Sprawa prefektów, tak często ujmowana w poprzednich fazach dyskusji nad projektami, znów znalazła swój oddźwięk we wnioskach kurialistów krakowskich; proponują dodanie, iż prefekci mają obowiązek brania udziału w konferencjach dekanalnych i uwzględniać porządek nabożeństw parafialnych. Polecają modyfikację art. 117 odnoszącego się do jednolitego lekcjonarza dla całej Polski. Autorzy stwierdzają, że skoro nie ma opracowanego tekstu Ewangelii należy w wymienionym artykule inaczej uformować myśl, np. „w brzmieniu przez Episkopat ułożonym”. W art. 131 proponują umieścić: „w atmosferze kościelnej w zdrowym i pogodnym, i szczerym nastroju", natomiast w 138 ostatnie zdanie umieścić w osobnym artykule.

${ }^{164}$ Wnioski arcbpa Nowowiejskiego (nr 2660) są obszerniejsze od poprzedniego listu. Proponuje następujące zmiany: do art. 6 zamiast: „exercitiis in communi vocandi”, lepiej uźyć: „exercitiis per tres vel amplius dies vocandi ad mutem Episcopoi”, do art. 10 zamiast: „usui personarum utriusque sexus”, lepiej: „usui publico”, czyli w ogóle unikać publicznych plaż. Do art. 47 po „Foveant” dodać: „curam animarum in schola ad curam animarum paroecialem adaptent clerumque adiuvet" - uczestniczyć we wspólnych manifestacjach religijnych, natomiast art. 109 należałoby opuścić. W dalszej częśsi listu Arcybiskup wylicza błędy językowe: art. 27 - zamiast „sint ad exemplum” powinno być ,exemplum imitandi”, w art. 28 zamiast „cappellanus” powinno być „capellanus”; w art. 62 - zamiast „religionum contemptui” powinno być „contemptui 
arcbp Jałbrzykowski (24 lipca) ${ }^{165}$, bp łomżyński (27 lipca) ${ }^{166}$, bp łucki (7 sierpnia $)^{167}$, Kuria Metropolitalna lwowska obrządku łacińskiego $(7 \text { sierpnia })^{168}$.

Kardynal Hlond dnia 9 sierpnia wyslal z Poznania odpis drugiego dekretu synodalnego legata datowany 2 sierpnia $1936 \mathrm{r}$.

W dniach 12-13 sierpnia 1936 roku odbyło się kolejne posiedzenie specjalnej Komisji synodalnej w Warszawie. Obecni tam kard. Hlond, arcbp Sapieha oraz biskupi Lisowski i Przeździecki przejrzeli i wprowadzili poprawki do projektu uchwal, wydrukowanego stosownie do polecenia powziętego na posiedzeniu z 3 lipca. Kardynał Hlond przesłał 12 sierpnia 1936 roku list (nr 1349) do wszystkich ordynariuszów, biskupów sufraganów i biskupów rezydujących w Polsce powiadamiający, iż legat przybędzie do Częstochowy pociągiem 23 sierpnia o godz. 9.14. Oznajmił, że biskupi witają legata w stroju liturgicznym przed bazyliką. Biskup Przeździecki listem z dnia 9 sierpnia (nr 1343) prosi bpa Szeptyckiego o wyznaczenie teologa greko-katolickiego. Prymas po posiedzeniu Komisji synodalnej wystosował do legata list w języku włoskim z zapytaniem, czy nie zechce przejrzeć projekt dekretu w sprawie porządku obrad sy-

omnis religionis”, w art. 93 należy dodać po słowie „infirmitatis” słowo „senectutis”, w art. 95 dodać po słowie ,valide” - „et licite”. Kolejne błędy to: art. 100 zamiast „private” powinno być „unice”, w art. 107 zamiast „earumque” lepiej „neque earundem”; w art. 130 dodać by należało po słowie „Quo" - „efficacius”, a w 144 zamiast „museis”, lepiej użyć „musaeis”.

${ }_{165}$ Arcybiskup wileński zaproponował cztery zmiany: w art. $57 \S 2$ zamiast „nie powinni należeć umieścić „nie mogą należeć”. Do tytułu De praefectis dodać „seu catechetis in scholis”. Podobnie w art. 62 do „promovere abstinentiam” dodać „ab alcoholismo”. W art. $69 \$ 3$ zamiast „religiones” lepiej użyć „ordines religiosi”.

${ }^{166}$ Biskup Lukomski postulował użycie lepszego sformułowania zamiast ,ad parochum private”, a w art. 115 wkradł się błąd drukarski - winno być „peregrinationibus”.

${ }^{167}$ Równie krótkie uwagi przesłał bp Szelążek. W art. 51 zaproponował opuścić „necnon leges et decreta Status cum Episcopatu concordata”, gdyż może to wywołać ataki na Episkopat. W art. $144 \S 1$ zamiast „per parochias” należałoby użyć „in paroeciis”.

${ }^{168}$ Wnioski lwowskiej Kurii Metropolitalnej podpisane zostały przez bpa Bolestawa (Twardowskiego). Wnioskodawcy zauważyli niezgodność art. $40 \$ 1$ z postanowieniami kan. 1507 co do iura stolae. Podobnie art. $90 \$ 1 \mathrm{z}$ kan. 733 oraz art. $148 \mathrm{z}$ kan. 1890 . Odnośnie do tego ostatniego, dyspozycja kanonu jest jasna - akta sprawy dostarcza sadowi trybunał a quo. Autorzy nie zgadzają się ze sformułowaniem art. 69 o Akcji Katolickiej, jako organizacji świeckich. Twierdzą, że sprzeciwia się to duchowi allokucji Papieża do asystentów AK we Włoszech (Castelgandolfo - lipiec 1936), w których ustalił, że jest to udział świeckich w hierarchii. Odnośnie do art. $100 \$ 2$ stawiają zarzut, iż wymaga więcej aniżeli dekret S.C. R. z 26 marca 1924 roku (AAS XVI, 171) do święcenia sztandarów wymaga jedynie, aby nie miały „aliquid embleme de se vetitum vel reprobatum”. 
nodalnych - co należało do kompetencji legata. Powiadomil również legata, iż Ministerstwo Spraw Zagranicznych wyznaczyło księcia Borkowskiego do jego dyspozycji. Zadaniem księcia było uzgodnić z legatem sposób uczestnictwa reprezentanta Rządu min. Świętosławskiego - w początkujących obrady synodalne uroczystościach liturgicznych ${ }^{169}$. List datowany był 12 sierpnia 1936 roku. Kard. Hlonda wysłał do bpa Przeździeckiego list, który dotarł do tego ostatniego 18 sierpnia. Zawiadamiał w nim, że przyjazd legata planowany jest na 23 sierpnia o godz. 9.02 do Częstochowy. Przedstawił też plan powitania: na dworcu legata witać mieli obaj kardynałowie, miejscowy biskup, bp Przeździecki wraz z funkcjonariuszami synodu. W bramie Lubomirskich legata mieli powitać ojcowie paulini. Kardynał podał też przebieg nabożeństwa inaugurującego obrady synodu; ostania dyspozycja dotyczyła uczestnictwa wszystkich obradujących w drodze krzyżowej 26 sierpnia, przed ostatnią sesją synodalną.

Nowo mianowany legat 19 sierpnia 1936 roku został przyjęty przez Piusa XI w Jego siedzibie w Castel Gandolfo. Po prywatnej rozmowie Legat przedstawił swoją świtę Papieżowi. Stanowili ją: ks. Prałat Stanisław Janasik - audytor Roty Rzymskiej, ks. prałat Tadeusz Zakrzewski - rektor Papieskiego Instytutu Polskiego, ks. prałat Jan Rosso - substytut Kongregacji ds. Kościoła Wschodniego, ks. prałat Józef Ferretto - mistrz ceremonii, ks. Artur Gervasi sekretarz, komandor Edward Giove - świecki szambelan papieski oraz hr. Maria Fani-Ciotti z papieskiej gwardii szlacheckiej.

Udzielone przez papieskie breve upoważnienia, w myśl kan. 281, zezwalały kard. Marmaggi'emu, jako legatowi a latere, na podjęcie kolejnych proceduralnych kroków. Wydał on w Rzymie dnia 2 sierpnia dekret zwołujący na 25 i 26 sierpnia 1936 roku do Częstochowy synod plenarny. Także 2 sierpnia ukazał się jego drugi dekret o tych, którzy są zaproszeni na ten synod. Z głosem decydującym zaproszeni zostali: kard. Hlond, arcbp Edward Ropp (Mohylew), bp Czar-

${ }^{169}$,'E di competenza del Legato di decretare l'ordine da sequirsi nelle trattazioni del Concilio. A questo riguardo mi permatto di sottoporne al. Suo benigno esame il progetto di un decreto in questa materia. (...) Il Governo ha invitato, come Vostra Eminenza qia lo sa, al. Confine il cante Borkowski del Ministero degli Esteri col compito di essere a Sua disposizione per il protocollo ed anche per determinare d'accordo coll'Eminenza Vostra il modo della partecipazione del rappresentante del Governo, ministro Świętosławski, all’inizio liturgico del Concilio nella Basilica”. 
necki (wizytator apostolski obrządku bizantyńsko-słowiańskiego), bp Józef Gawlina (ordynariusz polowy) i wszyscy biskupi tytularni zamieszkali na terenie Polski. Z glosem doradczym zostali zaproszeni po jednym delegacie kapituł metropolitalnych i katedralnych, delegaci z Katolickiego Uniwersytetu w Lublinie, fakultetów teologicznych Uniwersytetu Warszawskiego, Krakowskiego, Lwowskiego i Wileńskiego, nadto ks. Stanisław Bross - dyrektor Akcji Katolickiej oraz ordynariusze zakonów i zgromadzeń kościelnych. Autorem listy uczestników obrad synodalnych był kard. Hlond, który w tym czasie przebywal na kuracji w Bagnoles de l'Orne.

Dopełniwszy swoich proceduralnych obowiązków w Rzymie kard. legat wyruszył z misją do Polski. Oddany przez władze włoskie do dyspozycji Legata wagon salonowy wyjechal z Rzymu 21 sierpnia 1936 roku o godz. 23.30. Dnia 23 sierpnia, w niedzielę, wczesnym rankiem pociąg $\mathrm{z}$ Wiednia ${ }^{170} \mathrm{z}$ osobą legata przekroczył granicę polską w Zebrzydowicach ${ }^{171}$. W imieniu rządu RP powital Legata wojewoda Grażyński, natomiast w imieniu Episkopatu polskiego - bp Adamski. Urzędowe powitanie miało miejsce na dworcu kolejowym w Katowicach. O godz. 9.00 kard. Marmaggi był już witany na dworcu w Częstochowie. Oczekiwali na niego kard. Kakowski, kard. Hlond, bp Kubina i bp Przeździecki, w otoczeniu natariuszów synodu: ks. Infułata Lipińskiego, ks. Prałata Rychtera, ks. Prałata Kaczyńskiego. Z ramienia rządu Legata przywitali wojewoda śląski Dziadosz i gen Gąsiorowski. Przemówienie powitalne w języku łacińskim ${ }^{172}$ wygłosił biskup Kubina, na które odpowie-

${ }^{170} \mathrm{~W}$ Wiedniu legat przesiadł się do wagonu dostarczonego przez władze polskie.

${ }^{171}$ Legat przekroczywszy granicę Polski przesłał prezydentowi Rzeczypospolitej Polskiej telegram: „Jego Ekscelencja Ignacy Mościcki, Prezydent Rzeczypospolitej Polskiej - Warszawa. Ponownic wstępujacc na ziemie Rzeczypospolitej, by jako legat Ojca św. Przewodniczyć na pierwszym plenarnym Synodzie w Polsce, śpieszę przesłać Waszej Ekscelencji wyrazy głębokiej czci wraz z zapewnieniem, że w sławnej świątyni Częstochowskiej zaniosę najgorętsze modły za wielkość i pomyślność ukochanej Polski. Franciszek Marmaggi, Legat”. Telegram powitalny przesłał również prezydent RP: „Jego Eminencja Kardynał Legat Franciszek Marmaggi - Częstochowa. Wyrażając wdzięczność za ofiarowanie modłów na intencję Rzeczypospolitej Polskiej oraz dziękując za uprzejme wyrazy pod moim adresem, ze swej strony witam Waszą Eminencję, jako Legata Ojca św. na ziemi polskiej, prosząc o przyjęcie wyrazów wysokiego poważania”.

${ }^{172}$ K. Jastrzębski, Synod Plenarny na Jasnej Górze, Gazeta Kościelna 44 (1937), s. 16. Przemówienie bpa Kubiny: „Eminencjo! Zaledwie dwa i pół miesiąca minęło od chwili, gdy po tylu latach, które dobrze czyniąc przeżyłeś wśród naszego narodu, wróciłeś do Rzymu i gdy Częstochowa razem z cała Polską - z bólem Ciebie musiała pożegnać. 
dział Legat, stwierdzając, iż Polska stojąca na straży cywilizacji chrześcijańskiej jest bliska sercu Ojca św. oraz samego Legata, który zdążył ją poznać pracując w Polsce.

W głównej bramie jasnogórskiego klasztoru powitał legata generał oo. Paulinów o. Pius Przeździecki, podkreślając rolę jaką przyszło odgrywać Polsce wobec zagrożeń ze Wschodu i Zachodu, które stają się niebezpieczne dla Europy. Po tym przemówieniu ruszyła procesja do klasztoru. Zgodnie $\mathrm{z}$ przewidzianym programem przed klasztorną bramą legata papieskiego witali biskupi wszystkich obrządków i władz państwowych. Następnie wszyscy przeszli do bazyliki na krótkie modlitwy. Po nich przemówienie wyglosil kard. Prymas witając legata. Na to przemówienie odpowiedział legat, zwracając uwagę na doniosłą rolę Polski w dobie ogólnego chaosu. Na zakończenie udzielił obecnym apostolskiego błogosławieństwa. Po tym wstępie wszyscy udali się do kaplicy Cudownego Obrazu, gdzie bp Gawlina odprawił Mszę św.

W tym samym dniu, 23 sierpnia, kard. Marmaggi wydał dekret dotyczący porządku obrad synodalnych ${ }^{173}$. Została określona do-

Smutek nasz był wówczas głębszy, gdyż nikłą tylko mogliśmy żywić nadzieję, że dostojną osobę Twoją znowu w Polsce ujrzymy. Lecz Opatrzność zrządziła, że możemy dziś znowu widzieć Cię i powitać w mieście naszym. Radość nasza z tej szczęśliwej od Boga danej okazji jest tym większa, że przychodzisz do nas przysłany bezpośrednio przez naszego Ojca św. Piusa XI, jako Jego legat, celem spełnienia wielkiego dzieła, abyś przewodniczyl synodowi plenarnemu Rzeczpospolitej Polskiej, który zwołałeś do sławnego sanktuarium Najświętszej Marii Panny w mieście naszym. Zaprawdę trudno byłoby znaleźć osobistość odpowiedniejszą i godniejszą od Ciebie do spełnienia tego zadania. Ty bowiem najlepiej poznałeś warunki Kościoła w Polsce, jego trudności i dążenia, jako też ducha kleru i narodu naszego i nie tylko poznałeś nas i naszą Ojczyznę, ale jak tego doświadczyliśmy, źywisz dla nas i Ojczyzny naszej szczerą miłość. Dlatego jesteśmy przekonani, że synod plenarny pod Twoim światłym przewodnictwem da jak najlepsze wyniki i otworzy w Ojczyźnie naszej obfite źródła siły w Chrystusie i pomnożą w Ojczyźnie naszej Królestwo Chrystusowe i jego pokój. W ten sposób uwieńczysz wielkie dzieło, tak pięknie rozpoczęte w Polsce przez naszego Ojca św. Papieża Piusa XI i tak znakomicie przez Ciebie, jako nuncjusza apostolskiego w dalszym ciagu prowadzone. Samej zaś Częstochowie Twoja obecność i Twoja działalność przyniesie nowy splendor. Nie dziwię się, że dziś razem ze mną Tobie oddanym sługą cała Częstochowa - władze cywilne i wojskowe, duchowieństwo i wierni z niezwykłą radością Cię witają, wołając z głębi serca: „Błogosławiony, który idzie w imię Pańskie”, błagając zarazem gorąco NMP, Królowę Korony Polskiej: „Módl się za naszego Ojca św. Piusa XI, módl się za jego legata J. E. Ks. Kardynała Franciszka Marmaggi”.

${ }^{173} \mathrm{~W}$ aktach Kurii siedleckiej, zatytułowanych „Materiały dotyczące protokołu oraz wnioski na synod" bez oznaczeń liczbowych, znajduje się opracowanie pisane na maszynie dotyczące porządku nabożeństw i ceremonii synodalnych. Szczegółowy rozkład czynności obejmował dni od 23 sierpnia do 26 sierpnia 1936 roku. 23 sierpnia o godz. 
9.15 biskupi zgromadzeni przed bramą ks. Lubomirskiego mieli powitać legata. Ojciec generał Pius Przeździecki mial powitać legata najpierw w języku lacińskim, a potem w języku polskim. Kolejny punkt, to odśpiewanie pieśni „Kto się w opiekę odda”, poczym wszyscy mieli się udać do bazyliki. W wielkich drzwiach bazyliki witać miat cały episkopat, po czym nastąpić miało pocałowanie krzyża i inne ceremonie, po których procesja miała ruszyć dalej ku wnętrzu bazyliki. Równocześnie chór pod dyrekcją Wawrzynowicza śpiewać mial „Tu es Petrus”. Przeor po zajęciu wyznaczonych miejsc odśpiewać miał modlitwy z pontyfikału. Kolejny punkt programu to przemowa kard. Hlonda, po której biskupi mieli udać się do cudownej kaplicy. W niej miano odprawić mszę św., po której episkopat udać się miał do klasztoru. Wszystkie organizacje religijne oraz pozostali wierni mieli zgromadzić się na placu przed Szczytem jasnogórskim, gdzie miała zostać odprawiona suma $z$ kazaniem o godzinie 10.30 . Wieczorem o godzinie 19.30 odbyć się miała procesja mariańska na wałach oraz nabożeństwo $\mathrm{z}$ kazaniem.

Dnia następnego, 24 sierpnia w poniedzialek od godziny 10.00 przewidziano konferencję Episkopatu Polski, która trwać miała do godz. 13.00, a od godz. 16.00 sesja z członkami kapituł, uniwersytetów i zakonów.

W dniu rozpoczęcia się obrad synodalnych, 25 sierpnia we wtorek o godzinie 9.30 procesja uczestników synodu miała wyruszyć z klasztoru przez Salę Rycerską, plac wewnętrzny koło pokoi królewskich i arsenału do bazyliki. Przewidziano szyk procesjonalny; najpierw iść mieli księża notariusze, teologowie i prawnicy. Po nich postępować mieli przełożeni prowincjalni i generalni zakonów. W dalszej kolejności delegaci uniwersytetów, kapituł, biskupi tytularni, ordynariusze i arcybiskupi, kardynałowie i na końcu legat. W tym czasie przewidziano śpiewanie antyfony „Tu es Petrus”. Po dotarciu do bazyliki Prymas miał odprawić mszę św., po której zakończeniu należało odśpiewać hymn "Veni Creator” i litanię do Wszystkich Świętych. Po zakończeniu tych czynności miał nastąpić pow rót do ołtarza przez główne wejście do zakrystii i dalej przez klauzurę do Sali Rycerskiej. Po tej ceremonialnej części mialy rozpoczać się obrady synodalne, które miały trwać do godz. 13. Po południu o godz. 13.15 - obiad i po krótkim odpoczynku dalszy ciąg obrad, które trwać miały do godz. 19.00. Kolację przewidziano na godz. 19.15 .

W programie umieszczono plan nabożeństw, które miały się odprawiać równolegle do obrad synodalnych w dniach 25, 26 i 27 sierpnia. O godz. 6.00 miała być odprawiana msza prymaryjna z kazaniem w Cudownej Kaplicy; o godz. 10.30 - suma z kazaniem; o godz. 15.30 - nieszpory w bazylice, a o godz. 16.00 różaniec z kazaniem w Cudownej Kaplicy. 25 sierpnia o godz. 15.15 przewidywano odprawienie drogi krzyżowej na Wałach, a o godz. 20.00 procesję na nich i nabożeństwo maryjne na Szczycie. Zastrzeżono, że kapłani nie należacy do grona uczestników synodu nie mogą odprawiać mszy św. na Jasnej Górze w godz. 5.30-8.30. Msze przez czas trwania synodu moźna odprawiać od godz. 24.00. Uczestnicy synodu mieli otrzymać odznaki dające wstęp do klasztoru i na jego obrady. W dniach od 23 do 26 sierpnia wstęp do klasztoru mieli tylko uczestnicy synodu.

Pozostawiając przebieg dalszych sesji synodalnych późniejszym rozstrzygnięciom program przewidywał kolejność czynności końcowych synodu: uczestnicy synodu przechodzą do bazyliki, gdzie miano odśpiewać hymn Te Deum, po którym legat udzielić miał benedykcji. W końcu miała się odbyć procesja eucharystyczna na Wałach.

Kolejna karta wyżej wspomnianych akt zawiera szczególowe rozstrzygnięcia co do przebiegu samych obrad. Dzień 25 sierpnia wypełniony miał być następujacymi czynnościami: godz. 9.30 - procesja zgodnie z porządkiem przewidzianym w poprzedniej karcie. Po mszy św. uczestnicy mieli złożyć wyznanie wiary. Po litanii legat miał odśpiewać trzy inwokacje. O godz. 11.00 rozpoczać się miała I sesja według następującego porząd- 
kładnie przewidywana kolejność czynności synodalnych, wyznaczając ich początek na 25 sierpnia, na godz. 9.30. Zgodnie z procedurą odbywania synodów zgromadzenie to miało rozpocząc się Mszą św., odśpiewaniem hymnu Veni Creator, odczytaniem wyznania wiary, odmówieniem litanii do Wszystkich Świętych. Miało to mieć miejsce o godz. 9.30, po czym o godz. 11.00 odbyć się miała I sesja synodalna, której otwarcia miał dokonać legat. Gwoli dopełnienia formalnych obowiązków na tej sesji miały być odczytane dekrety wydane przed synodem oraz wyloniona miała być komisja celem sprawdzenia obecności wezwanych na synod. Tego samego dnia o godz. 16 miała się odbyć II sesja synodalna. Na godzinę 11 dnia 26 sierpnia przewidziano odbycie III sesji, której zadaniem, tak jak i poprzedniej, było odczytanie artykułów projektu uchwał synodalnych oraz dyskusja nad nimi. Termin IV sesji, ostatniej, przewidziano na godz. 16.00 tego samego dnia. Jej zadaniem było przyjęcie dekretów synodalnych oraz omówienie listu do Ojca św. w sprawie ogłoszenia dogmatu Wniebowzięcia NMP. Zakończenie miało stanowić odśpiewanie hymnu Te Deum.

Dnia 24 sierpnia odbyła się ostatnia przed synodem Konferencja Episkopatu Polski, dotycząca omówienia spraw związanych z rozpoczynającym się następnego dnia synodem.

ku: mowa kard. Kakowskiego do legata, mowa legata otwierajaca kanonicznie synod, odczyt dekretów legata o zwołaniu, o uczestnikach, o porządku obrad synodalnych, wybór sekretarza synodu i zatwierdzenie notariuszów, teologów i prawników, wybór Komisji weryfikacyjnej, obrady nad projektami uchwal synodalnych. Projekt miały być czytane całymi rozdziałami, po czym następować miała dyskusja nad poszczególnymi artykułami. Uchwały zapadać miały nad całymi rozdziałami po przyjęciu lub odrzuceniu poprawek. Referowanie poszczególnych rozdziałów miało przebiegać według następującego porzadku: kard. Prymas - I rozdzial, metropolita krakowski - rozdz. II i III, metropolita wileński - rozdz. IV do VIII włącznie, biskup tarnowski - rozdz. IX-XII włącznie, biskup podlaski - rozdz. XIII - XV. Na dzień 26 sierpnia przewidziano również dwie sesje. Od godz. 10.00 trwać miała III sesja, podczas której miały toczyć się obrady nad dalszym ciągiem projektu uchwał. W godzinach popołudniowych przewidziano IV sesje i zakończenie obrad a pod ich koniec sformułowanie listów postulacyjnych do Ojca św., prośby o ogłoszenie dogmatu o Wniebowzięciu NMP, prośby o kanonizację blogosławionej Kingi, beatyfikację pap. Innocentego XI. Napisać postanowiono odezwę w związku z jubileuszem 500-lecia Soboru florenckiego. Kolejny punkt programu to napisanie listu do biskupów Hiszpanii. Na zakończenie synodu przewidziano przemówienie dziękczynne kard. Prymasa i przemówienie legata, a po nim błogosławieństwo kończące synod.

Inna nienumerowana karta podawała modlitwy odmawiane podczas sesji synodalnych. 


\section{Zakończenie}

Tak zakończył się okres przygotowań do pierwszego polskiego synodu plenarnego w Polsce. Okres ten, trwający okolo 10 lat, nacechowany był wielką determinacją polskiej hierarchii kościelnej. Historyczne zmiany, a co za tym idzie przemiany ekonomiczne, społeczne i światopoglądowe nie sprzyjały szybkim pracom. Obejmowały one całą strukturę Kościoła, zarówno duchowieństwo, jak i wiernych świeckich. Prace te były właściwie obliczonym na wiele lat procesem przemiany w świadomości wielu ówczesnych wiernych. W liczbie odbytych konferencji, wydanych dekretów, krążących listów i ankiet oraz pism z postulatami, wnioskami i opiniami, kryje się cały ogrom wysiłku pokonującego opór materii przyzwyczajeń, niechęci, różnic wynikających z dzielnicowości. Z tego, że projekt statutu, który mial być podstawą do końcowych dyskusji i zatwierdzenia przez Synod, byl obliczony na dokonanie wielkich przemian zrodził się obowiązek perfekcyjnego opracowania sytuacji Kościoła w nowych warunkach. Wydaje się, że biskupi polscy sprostali temu wielkiemu wyzwaniu. Artykuł niniejszy pragnie ukazać proces tworzenia się partykularnego ustawodawstwa kościelnego, które obowiązywało bez mała do końca XX wieku. I to właśnie świadczy o wielkości podjętego przez biskupów dzieła.

\section{Die erste polnische Synode in der unabhangigen Republik Polen Vorbereitungsphase}

Eines der wichtigsten Ereignisse der polnischen Kirche des XX. Jh. war eine Synode in der Zwischenkriegszeit. Das war die erste Synode nach 150 Jahren der Unterdrückung. Sie fand am 17. August 1936 statt. Die Vorbereitungsphase, 1927-1936, war von einer großen Mühe gezeichnet. Die Mühe betraf vor allen Dingen die Anpassung der polnischen einzelnen Vorschriften an die gültigen Vorschriften des Rechtes der gemeinen Kirche. Die Erlangung der Unabhängigkeit von Polen (1918) deckte sich mit der Bekanntgebung des neuen Kodeks des kanonischen Rechtes (1917). Der Wiederaufbau der polnischen Staatlichkeit, zu der Reorganisation des Kirchenlebens gehörte, bestand in der Wiedervereinigung der polnischen Gebiete nach der Teilung, der Vereinheitlichung der Gottesdienstordnung, Disziplin der Geistlichen and der Organisation der seelsorgischen Arbeit u. s. w. 
Ziel der Arbeit ist die Vorstellung des Prozesses des Schaffens der partikularen kirchlichen Gesetzgebung, die von 1936 bis beinahe Ende des XX. Jh. gültig war. Diese Tätigkeit der Kirche trug zur Verstärkung der Einheit der polnischen Gesellschaft and zum Wiederaufbau des Staates bei. Das ist eine große and zugleich unterschätzte Leistung. 